\title{
Ruthenium(II) Complexes Containing Lutidine-derived Pincer CNC Ligands: Synthesis, Structure and Catalytic Hydrogenation of $\mathrm{C}=\mathrm{N}$ bonds
}

Martín Hernández-Juárez, ${ }^{[b]}$ Joaquín López-Serrano*, ${ }^{\left[{ }^{[a]}\right.}$ Patricia Lara, ${ }^{[a]}$ Judith P. Morales-Cerón, ${ }^{[b]}$ Mónica Vaquero, ${ }^{[a]}$ Eleuterio Álvarez, ${ }^{[a]}$ Verónica Salazar ${ }^{[b]}$ and Andrés Suárez ${ }^{\star[a]}$

[a] Dr. J. López-Serrano, Dr. P. Lara, Dr. M. Vaquero, Dr. E. Álvarez, Dr. A. Suárez

Instituto de Investigaciones Químicas (IIQ) and Centro de Innovación en Química Avanzada (ORFEO-CINQA)

CSIC and Universidad de Sevilla

Avda Américo Vespucio, 49; 41092, Sevilla, Spain

E-mail: joaquin.lopez@iiq.csic.es

andres.suarez@iiq.csic.es

[b] Dr. M. Hernández-Juárez, J. P. Morales-Cerón, Prof. V. Salazar

Centro de Investigaciones Químicas.

Universidad Autónoma del Estado de Hidalgo

Carretera Pachuca-Tulacingo Km 4.5, 42184, Mineral de la Reforma, Hidalgo, Mexico.

\section{Abstract}

A series of Ru complexes 3-5 containing lutidine-derived pincer CNC ligands have been prepared by transmetallation with the corresponding silvercarbene derivatives 2. Characterization of these derivatives shows both mer and fac coordination of the CNC ligands depending on the wingtips of the $\mathrm{N}$ heterocyclic carbene fragments. Ru-CNC complexes 3-4 are active, in the presence of $t B u O K$, in the hydrogenation of a series of imines. In addition, these complexes also catalyze the reversible hydrogenation of phenantridine. Detailed NMR studies have shown the capability of the CNC ligand to be deprotonated and get involved in ligand-assisted activation of dihydrogen. More interestingly, upon deprotonation, Ru-CNC complex $\mathbf{5 e}\left(\mathrm{BF}_{4}\right)$ is able to add aldimines to the 
metal-ligand framework to yield amido complexes 10. Finally, investigation of the mechanism of the hydrogenation of imines has been carried out by means of DFT calculations. The calculated mechanism involves outer-sphere stepwise hydrogen transfer to the $\mathrm{C}=\mathrm{N}$ bond assisted either by the pincer ligand or a second coordinated $\mathrm{H}_{2}$ molecule.

\section{Introduction}

In the last years, metal-ligand cooperation has become an important concept in both organometallic chemistry and catalyst development. ${ }^{[1,2]}$ Particularly, metal complexes incorporating neutral tridentate PNX $(X=$ phosphane, hemilabil $N$-donor) ligands based on a picolyl fragment and bulky electron-rich phosphanes are a prominent class of derivatives due to their ability to activate $\mathrm{H}-\mathrm{Y}(\mathrm{Y}=\mathrm{H}, \mathrm{O}, \mathrm{N}, \mathrm{C}, \mathrm{S})$ bonds. ${ }^{\left[{ }^{2]}\right.}$ In these complexes, deprotonation of the methylene carbons gives dearomatized species that are capable of bond activation in a ligand-metal cooperative process. In addition, the nucleophilic character of the dearomatized ligands ${ }^{[3]}$ allows M-PNX to function as metalbased frustrated Lewis pairs (FLP) ${ }^{[4]}$ in the activation of electrophiles such as $\mathrm{CO}_{2}$, carbonyl compounds and nitriles. ${ }^{[5]}$

Also, of particular importance, Milstein and coworkers exploration of RuPNX complexes (Figure 1), and their deprotonated counterparts, have led to the development of sustainable, atom-economical catalytic hydrogenation and dehydrogenation reactions of polar substrates. ${ }^{[6,7]}$ Examples of these reactions include the hydrogenation of carboxylic acid derivatives such as esters, amides, formates, ureas, carbamates and organic carbonates, ${ }^{[6 \mathrm{~b}-f]}$ nitriles, ${ }^{[6 \mathrm{~g}]} \mathrm{CO}_{2},{ }^{[6 \mathrm{~h}-j]}$ and processes involving the acceptorless dehydrogenation of alcohols. ${ }^{[7]}$

[Figure 1]

Since substitution of phosphane ligands by $N$-heterocyclic carbenes (NHC) has resulted in the improvement of several important catalytic processes, ${ }^{[8]}$ replacement of P-donors in Ru-PNP and PNN complexes by more 
electron-donating $\mathrm{NHC}$ congeners may offer new opportunities for electronic and steric modification of the metal center, while at the same time maintaining the acidity of the pyridylic protons. Based on this approach, some examples of metal complexes containing $\mathrm{CNN}$-type pincers derived from lutidine have been reported. For example, the groups of Song ${ }^{[9]}$ and Milstei ${ }^{[10]}$ have independently reported Ru-CNN complexes with an hemilabile amine or pyridine fragment, respectively. These derivatives provide very active catalysts in the hydrogenation of esters, in some cases outperforming their Ru-PNN counterparts. Similarly, Iglesias, Sánchez and coworkers have employed supported Ru-CNN complexes in the dehydrogenation of alcohols and in the transfer hydrogenation of ketones. ${ }^{[1]}$ The latter group has also reported the formation of Ru-CNC complexes that exhibit a moderate activity in the dehydrogenation of alcohols. ${ }^{[11]}$ Recently, during the progress of our work, Pidko and coworkers have described the use of Ru-CNC complexes in the hydrogenation of $\mathrm{CO}_{2}$ and esters. ${ }^{[12]}$

Reduction of imines to their corresponding amines is an important transformation in organic synthesis. While a variety of metal hydrides may be used in this reaction, the use of $\mathrm{H}_{2}$ has a significant interest as a clean and atom economical reductant both in laboratory and industrial settings. ${ }^{[13]}$ However, in comparison with the hydrogenation of other unsaturated bonds, such as olefins and ketones, there is still a lack of mechanistic understanding of these reductions. ${ }^{[13 d]}$ Among the catalytic systems that promote the (enantioselective) hydrogenation of $\mathrm{C}=\mathrm{N}$ bonds, ruthenium(II) catalysts incorporating acid-base responsive ligands based on $\mathrm{OH}$ and $\mathrm{NH}$ functionalities, including Shvo- and Noroyi-type complexes, have been found to be particularly effective. ${ }^{[14]}$ These catalysts are thought to operate by $\mathrm{H}_{2}$ activation involving the metal and the basic ligand fragment, followed by a (concerted) transfer of the hydridic and acidic hydrogens to the iminic carbon and the $\mathrm{N}$ atom, respectively. ${ }^{[13 d, 14 a, 14 f-g]}$

Based on these precedents, we anticipated that lutidine-derived pincer $\mathrm{Ru}$ complexes might provide efficient catalysts for the hydrogenation of substrates containing $\mathrm{C}=\mathrm{N}$ bonds. Hence, in a previous communication, we have described the synthesis and acid-base reactivity of fac-coordinated RuCNC complexes, and preliminary studies of their application in the 
hydrogenation of imines. ${ }^{[15]}$ Herein, we provide a full account of our research on this topic including a detailed study of the structural features of Ru complexes containing $\mathrm{N}$-heterocyclic carbene pincer CNC ligands, as well as their catalytic performance in the hydrogenation of $\mathrm{C}=\mathrm{N}$ bonds. In addition, insights into the mechanism of this process have been obtained from the spectroscopic study of reaction intermediates and DFT calculations.

\section{Results and Discussion}

\section{Ru-CNC complexes}

Attempted preparation of ruthenium complexes incorporating CNC ligands was performed by reaction at low temperature of the imidazolium salt $1 \mathrm{a}(\mathrm{Br})$ with different $\mathrm{Ru}$ precursors $\left(\mathrm{RuHCl}\left(\mathrm{PPh}_{3}\right)_{3}, \quad \mathrm{RuCl} \mathrm{PPh}_{3}\right)_{3}$, $\left.\mathrm{RuHCl}(\mathrm{CO})\left(\mathrm{PPh}_{3}\right)_{3}, \mathrm{RuH}_{2}(\mathrm{CO})\left(\mathrm{PPh}_{3}\right)_{3}\right)$ in the presence of a base (Li(HMDS), tBuOK, NaH). Contrary to previously observed, this approach did not provide clean reactions, probably as a consequence of the acidity of the methylene protons of the $\mathrm{CNC}$ ligand. $\mathrm{N}$-Heterocyclic carbene transfer with $\mathrm{Ag}-\mathrm{NHC}$ complexes to different metals has developed into a well-established methodology for the preparation of metal-NHC complexes under mild conditions. ${ }^{[16]}$ Hence, an alternative procedure based on the transmetallation with $\mathrm{Ag}-\mathrm{NHC}$ complexes 2 was sought (Scheme 1). Complexes 2 were obtained by reaction of bis-imidazolium salts 1 with $\mathrm{Ag}_{2} \mathrm{O}$ in $\mathrm{CH}_{2} \mathrm{Cl}_{2}$, as noted by the disappearance of the imidazolium proton signals in the ${ }^{1} \mathrm{H}$ NMR spectra and appearance of relatively broad signals at ca. $180 \mathrm{ppm}$ in the ${ }^{13} \mathrm{C}\left\{{ }^{1} \mathrm{H}\right\}$ NMR experiments due to the $\mathrm{C}^{2}$ carbons of the $\mathrm{NHC}$ moieties. ${ }^{[17]}$ Elemental analysis and NMR spectroscopy data are in agreement with the proposed elemental formulation for derivatives 2 . In addition, to confirm the proposed structures in the solid state, derivatives $2 \mathbf{a}(\mathrm{Br})$ and $2 \mathbf{d}(\mathrm{Cl})$ have been studied by singlecrystal X-ray diffraction (Figure 2). The solid state structures consist of monomeric units with each $\mathrm{NHC}$ fragment coordinated to a Ag-halogen moiety. The coordination geometry at the metal atom is roughly linear ( $\mathrm{C}-\mathrm{Ag}-\mathrm{Br}$ $165.68^{\circ}$; $\mathrm{C}-\mathrm{Ag}-\mathrm{Cl} 166.75^{\circ}$ ), and there exists weak $\mathrm{Ag}(\mathrm{I})-\mathrm{Ag}(\mathrm{I})$ intramolecular 
interactions of $3.32 \AA(\mathbf{2} \mathbf{a}(\mathbf{B r})$ ) and $3.24 \AA(\mathbf{2} \mathbf{d}(\mathbf{C l}))$ (sum of van der Waals radii: $3.44 \AA$ A $)$.

[Scheme 1]

[Figure 2]

Ruthenium complexes $3 a(C l)$ and $3 \mathbf{b}(\mathbf{C l})$ were prepared from the appropriate silver reagent 2 and $\mathrm{RuHCl}(\mathrm{CO})\left(\mathrm{PPh}_{3}\right)_{3}$ in THF at $55{ }^{\circ} \mathrm{C}$ (Scheme 1). Similarly, complexes $\mathbf{3} \mathbf{a}\left(\mathbf{B F}_{4}\right)$ and $\mathbf{3} \mathbf{c}(\mathbf{B r})$ were obtained from the corresponding bromine derivatives $2 \mathrm{a}(\mathrm{Br})$ and $2 \mathrm{c}(\mathrm{Br})$, after treatment with $\mathrm{NaBF}_{4}$ or $\mathrm{NaBr}$, respectively. Finally, the synthesis of the xilyl-substituted derivative $3 \mathbf{d}(\mathrm{Cl})$ was more conveniently carried out in $\mathrm{CH}_{2} \mathrm{Cl}_{2}$ at room temperature. Complexes $\mathbf{3}$ are obtained as yellow solids after recrystallization from $\mathrm{MeOH} /$ toluene solutions. They are stable in the presence of atmospheric agents in the solid state, although they slowly decompose in chlorinated solvents. Electrospray mass spectroscopy investigation of complexes $\mathbf{3}$ produces peaks consistent with the expected molecular ion $[\mathrm{M}]^{+}$. Fragmentation of $[\mathrm{M}]^{+}$gives rise to peaks assignable to the loss of $\mathrm{PPh}_{3},\left[\mathrm{M}-\mathrm{PPh}_{3}\right]^{+}$. Complexes 3 have been fully characterized by NMR techniques, and they show very similar features. For example, both ${ }^{1} \mathrm{H}$ - and ${ }^{13} \mathrm{C}\left\{{ }^{1} \mathrm{H}\right\}$ NMR spectra reflect the non-equivalence of the two halves of the CNC ligand. For complex $3 a(C l)$, the hydrido ligand produces in the ${ }^{1} \mathrm{H}$ NMR spectrum a doublet centered at $-7.38 \mathrm{ppm}\left(\mathrm{J}_{\mathrm{HP}}=30.4 \mathrm{~Hz}\right)$, while the methylene protons of the CNC ligand give rise to four different doublet signals in the range 4.1-5.7 ppm. The ${ }^{13} \mathrm{C}\left\{{ }^{1} \mathrm{H}\right\}$ NMR spectrum contains one doublet signal for each $\mathrm{C}^{2}$ carbon atom of the $\mathrm{NHC}$ fragment at $180.4\left(J_{\mathrm{CP}}=81 \mathrm{~Hz}\right.$, trans to $\left.\mathrm{PPh}_{3}\right)$ and $187.9 \mathrm{ppm}\left(J_{\mathrm{CP}}=8 \mathrm{~Hz}\right.$, trans to $\mathrm{H}$ ), whereas the carbonyl ligand signal appears at $209.2 \mathrm{ppm}$ as a doublet $\left(J_{C P}=15 \mathrm{~Hz}\right)$. Finally, the ${ }^{31} \mathrm{P}\left\{{ }^{1} \mathrm{H}\right\}$ NMR spectrum of complex $3 \mathbf{a}(\mathrm{Cl})$ shows a singlet at $42.4 \mathrm{ppm}$. These data supports a fac coordination of the CNC ligand, for which one carbene donor is situated trans to the hydrido ligand and the other is trans to the phosphane. ${ }^{[18]}$ This coordination geometry has been further confirmed by a $\mathrm{X}$-ray diffraction analysis of derivative $\mathbf{3 a}\left(\mathbf{B F}_{4}\right)$ (Figure 3). ${ }^{[15]}$ 
[Figure 3]

In order to determine differences in the donor strength of the different $\mathrm{CNC}$ ligands, the $\mathrm{CO}$ stretch bands in the IR spectra of complexes 3 in $\mathrm{CH}_{2} \mathrm{Cl}_{2}$ solution have been analyzed. Lower absorption energies in the range 1919-1924 $\mathrm{cm}^{-1}$ have been found for alkyl substituted complexes $\mathbf{3 a}(\mathbf{C l})$, $\mathbf{3 b}(\mathrm{Cl}), \mathbf{3 c}(\mathrm{Br})$ in comparison with derivative $\mathbf{3 d}(\mathbf{C l})$ that exhibit the same band at $1934 \mathrm{~cm}^{-1}$. Therefore a higher basicity of the alkyl-substituted CNC ligands may be expected.

The facial coordination of the pincer in complexes $\mathbf{3}$ is unusual in light of previously reported metal complexes containing structurally related $\mathrm{CNC}^{[11,12,18]}$ and CNN ligands. ${ }^{[9,10]}$ In order to compare the structure of the coordinated CNC ligands in complexes $\mathbf{3}$ with that observed in derivatives with a mer arrangement of the pincer, as well as to have Ru-CNC complexes without coordinated $\mathrm{PPh}_{3}$ available for mechanistic studies, we have prepared complexes $\mathbf{4 d}$ and $\mathbf{4 e}$. Derivative $\mathbf{4 e}$ was synthetized from the reaction in $\mathrm{CH}_{2} \mathrm{Cl}_{2}$ of $2 \mathrm{e}(\mathrm{Cl})$ and $\mathrm{RuHCl}(\mathrm{CO})\left(\mathrm{PPh}_{3}\right)_{3}$ (Scheme 2). ${ }^{[19]}$ In turn, reaction in THF at $60{ }^{\circ} \mathrm{C}$ of $\mathrm{RuHCl}(\mathrm{CO})\left(\mathrm{PPh}_{3}\right)_{3}$ and $\mathbf{2 d}(\mathbf{C l})$ provided a ca. $1: 4$ mixture of $4 \mathbf{d}$ and the cationic complex $\mathbf{3 d}(\mathbf{C l})$.

[Scheme 2]

The solution and solid state structures of mer-coordinated Ru-CNC complexes have been studied in detail. For example, good-quality crystals for a $X$-ray diffraction analysis of the mesityl derivative $4 e$ were grown from $\mathrm{CH}_{2} \mathrm{Cl}_{2}$ (Figure 4). The structure of complex $\mathbf{4 e}$ is comprised of a stereogenic $\mathrm{Ru}$ atom in an octahedral coordination geometry, with the carbene fragments of the pincer disposed trans to each other $\left(\mathrm{C}^{2}(\mathrm{NHC})-\mathrm{Ru}-\mathrm{C}^{2}(\mathrm{NHC})=170.0^{\circ}\right)$, and the carbonyl ligand trans to the pyridine. The two chelate rings of the pincer have boat conformations as determined by the dihedral angles $\mathrm{C}(5)-\mathrm{N}(1)-\mathrm{Ru}(1)-\mathrm{C}(20)$ and $\mathrm{C}(1)-\mathrm{N}(1)-\mathrm{Ru}(1)-\mathrm{C}(7)$ of $-35.5^{\circ}$ and $-34.1^{\circ}$, respectively. This causes a mesityl group to be aligned with the hydrido and the 
other with the chloride ligand, and therefore significantly different $\mathrm{Ru}-\mathrm{C}^{2}(\mathrm{NHC})$ distances are found $(R u(1)-C(7)=2.04 \AA \hat{;} ; R(1)-C(20)=2.13 \AA$ ) .

[Figure 4]

The ${ }^{1} \mathrm{H}$ NMR spectrum registered in $\mathrm{CD}_{2} \mathrm{Cl}_{2}$ at $238 \mathrm{~K}$ of $4 \mathrm{e}$ shows a singlet signal at $-16.2 \mathrm{ppm}$ for the hydrido ligand, and four non-equivalent signals for the ortho- $\mathrm{CH}_{3}$ groups of the mesityl wingtips. Also, the methylene protons produce three doublets in the range 4.8-5.4 ppm and a forth doublet significantly shifted downfield at $7.5 \mathrm{ppm}$. The significant deshielding of the latter signal may be attributed to the formation of an intramolecular halogenhydrogen bond, as expected from the examination of the X-ray structure of $4 \mathbf{e}$. In fact, in the solid state structure of $4 \mathbf{e}$ there is a very short $\mathrm{H}-\mathrm{Cl}$ contact $(2.42$ $\AA$; sum of van der Waals radii $=2.9-3.0 \AA$ ) between a methylene hydrogen and the chloride ligand. ${ }^{[20]}$ At room temperature, the ${ }^{1} \mathrm{H}$ NMR spectrum of $4 e$ shows significant line broadening indicative of the existence of a dynamic behavior in solution (see next). Similar NMR spectroscopy features are found for $\mathbf{4 d}$. Moreover, heating of a solution of $4 \mathrm{e}$ at $60{ }^{\circ} \mathrm{C}$ in $\mathrm{CD}_{3} \mathrm{OD}$ for $1 \mathrm{~h}$ shows partial deuteration $(90 \%)$ of the hydrido ligand, while prolonged heating over $16 \mathrm{~h}$ yields full deuteration of $\mathrm{RuH}$ and partial deuterium incorporation (75\%) in the $\mathrm{CH}_{2}$ arms, in line with the expected acidity of the methylene protons.

In the presence of $\mathrm{MeCN}$, chloride ligand decoordination in complexes 4 occurs, leading to the formation of the cationic complexes $\mathbf{5}(\mathbf{C l})$ (Scheme 2). ${ }^{1} \mathrm{H}$ NMR spectra in $\mathrm{CD}_{3} \mathrm{CN}$ of derivatives $5(\mathrm{Cl})$ are characterized by the presence of a singlet resonance at ca. $-14 \mathrm{ppm}$, attributable to the hydrido ligand, and four broad doublets in the region between 5.2-5.7 ppm produced by the methylene-bridge protons. In $\mathrm{CD}_{2} \mathrm{Cl}_{2}$ in the presence of $\mathrm{MeCN}$, complexes 4 and $\mathbf{5}(\mathrm{Cl})$ are in equilibrium in a temperature-dependent ratio, and a linear dependence of $\ln K_{\text {eq }}$ with temperature is evidenced. From the corresponding van't Hoff plots, values of $\Delta H^{0}=-8.67 \mathrm{kcal} / \mathrm{mol}$ and $\Delta S^{0}=-42.1$ eu for $4 \mathrm{e}$, and $\Delta H^{0}=-8.64 \mathrm{kcal} / \mathrm{mol}$ and $\Delta S^{0}=-43.9$ eu for $4 \mathbf{d}$ were calculated (see Supporting Information for details). Cleavage of the $\mathrm{Ru}-\mathrm{Cl}$ bond in complexes 4 with $\mathrm{NaBF}_{4}$ in $\mathrm{MeCN}$ yields adducts $\mathbf{5}\left(\mathrm{BF}_{4}\right)$ (Scheme 2). These derivatives have been fully characterized, and their spectroscopic data are in accord with a mer 
arrangement of the CNC ligands. For example, the ${ }^{1} \mathrm{H}$ NMR spectrum of $\mathbf{5 e}\left(\mathrm{BF}_{4}\right)$ shows similar features to that of $5 \mathrm{e}(\mathrm{Cl})$, including the appearance of the signal of the hydrido ligand as a singlet at $-14.5 \mathrm{ppm}$. The ${ }^{13} \mathrm{C}\left\{{ }^{1} \mathrm{H}\right\} \mathrm{NMR}$ spectrum exhibits the $\mathrm{C}^{2}$ carbon atoms of the $\mathrm{NHC}$ fragments at $190 \mathrm{ppm}$, while the carbonyl ligand signal appears at 206 ppm. Finally, in the IR spectrum the CO stretch band appears at $1932 \mathrm{~cm}^{-1}$.

The inferred structure of complexes $\mathbf{5}\left(\mathrm{BF}_{4}\right)$ has been confirmed by a crystal X-ray analysis of $\mathbf{5 d}\left(\mathbf{B F}_{\mathbf{4}}\right)\left(\right.$ Figure 5). ${ }^{[21]}$ Complex $\mathbf{5 d}\left(\mathbf{B F}_{\mathbf{4}}\right)$ exhibits an octahedral coordination around the $\mathrm{Ru}$ atom with the $\mathrm{CNC}$ ligand coordinated in a mer fashion $\left(\mathrm{C}^{2}(\mathrm{NHC})-\mathrm{Ru}-\mathrm{C}^{2}(\mathrm{NHC})=169.3^{\circ}\right)$, and the $\mathrm{CO}$ ligand situated trans to the pyridine fragment. Boat conformations of the two chelate rings of the pincer are defined by torsion angles of $\mathrm{C}(5)-\mathrm{N}(1)-\mathrm{Ru}(1)-\mathrm{C}(19)=-31.0^{\circ}$ and $\mathrm{C}(1)-\mathrm{N}(1)-\mathrm{Ru}(1)-\mathrm{C}(8)=-39.2^{\circ}$. In addition, $\mathrm{Ru}-\mathrm{C}^{2}(\mathrm{NHC})$ distances of 2.05 $\hat{A}(\mathrm{Ru}(1)-\mathrm{C}(8))$ and $2.08 \AA \hat{A}(\mathrm{Ru}(1)-\mathrm{C}(19))$ are observed.

[Figure 5]

As mention above, complexes $\mathbf{4}, \mathbf{5}(\mathbf{C l})$ and $\mathbf{5}\left(\mathbf{B F}_{4}\right)$ produce broadened signals at room temperature in the ${ }^{1} \mathrm{H}$ NMR spectra, indicative of the existence of a dynamic process in solution. For example, solutions of $\mathbf{5 e}\left(\mathbf{B F}_{\mathbf{4}}\right)$ in $\mathrm{CD}_{3} \mathrm{CN}$ show two sets of signals for the methylene protons in the ${ }^{1} \mathrm{H}$ NMR spectra registered at temperatures below $278 \mathrm{~K}$ : two doublets at 5.13 and $5.38 \mathrm{ppm}$ $\left({ }^{2} J_{\mathrm{HH}}=14.1 \mathrm{~Hz}\right)$, and two other doublets at 5.30 and $5.62 \mathrm{ppm}\left({ }^{2} J_{\mathrm{HH}}=15.6 \mathrm{~Hz}\right)$ (Figure 6). Rising of the temperature causes pairwise broadening of the signals, and their coalescence at 288 and $293 \mathrm{~K}$, respectively. Further heating of the sample gives rise to two geminally coupled doublets at 5.28 and $5.54 \mathrm{ppm}\left({ }^{2} \mathrm{~J}_{\mathrm{HH}}\right.$ $=15.0 \mathrm{~Hz}$ ). In square-planar palladium derivatives incorporating CNC ligands, a similar dynamic process has been attributed to a slow interconversion between the two twisted conformations adopted by both $\mathrm{C}^{2}(\mathrm{NHC})-\mathrm{N}(\mathrm{Py})-\mathrm{Pd}$ rings of the pincer ligand. ${ }^{[22]}$ Similarly, the observed dynamic behavior in derivatives $\mathbf{4}$ and $\mathbf{5}$ can be ascribed to the slow exchange between the two limiting enantiomeric forms (Scheme 3). Table 1 collects free energy barriers at the coalescence temperature estimated for the exchange of the environments of the para-methyl groups of the mesityl substituents for complexes $4 \mathbf{e}$ and $\mathbf{5 e}$, and of the $m-\mathrm{CH}_{3}$ 
of the xilyl wingtips for $\mathbf{4} \mathbf{d}$ and $\mathbf{5 d}$. Similar energy barriers have been found for complexes $\mathbf{4}$ and $\mathbf{5}$ containing the same ligand. For the latter complexes, however, no influence of the counteranion was observed in the exchanging process. In addition, the dynamic behavior is rather independent of the solvent. Hence, this exchange may be accompanied by previous chloride or $\mathrm{MeCN}$ ligand dissociation facilitated by the large trans influence of the hydrido ligand. ${ }^{[23]}$ Moreover, unlike it was observed with Pd-CNC complexes, the calculated barriers are consistently higher for species with xilyl-substituted CNC ligands than for derivatives containing the more encumbered pincer with mesityl groups, reflecting a likely case of steric assistance. ${ }^{[24]}$

[Figure 6]

[Scheme 3]

[Table 1]

\section{Catalytic hydrogenation of $\mathrm{C}=\mathrm{N}$ bonds}

Initial catalytic experiments were carried out with solutions of $\mathrm{N}$ benzylideneaniline (6a) in 2-methyltetrahydrofuran at $70{ }^{\circ} \mathrm{C}$ under 5 bar of $\mathrm{H}_{2}$ (Table 2). ${ }^{[25]}$ Under these conditions, complex $\mathbf{3 b}(\mathbf{C l})$, in the presence of $t \mathrm{BuOK}$, efficiently completes the reaction in $6 \mathrm{~h}$ using an S/C/B ratio of 1000/1/10 (entry 2). The rest of the series of complexes $\mathbf{3}$ also catalyzes the reduction of $\mathbf{6 a}$, although they provide significantly lower conversions (entries 1 and 3-4). In addition, catalyst precursor $4 \mathrm{e}$ exhibits a good catalytic activity for this reaction under the examined conditions (entry 5). Hydrogenation of derivatives bearing electron-releasing and -withdrawing groups can be carried out with complex $3 \mathbf{b}(\mathrm{Cl})$, however a significant influence of the nature of the substituents in the catalytic activity is evidenced (entries 6-9). Moreover, the hydrogenation of $\mathbf{6 f}$, having a hydroxyl group, can be accomplished although higher catalysts loading $(S / C=100)$ were needed to get acceptable conversions (entry 10). Finally, the hydrogenation of $\mathrm{N}$-alkyl substituted aldimines was examined (entries 11 and 12). $N$-Benzylidenebenzylamine $(\mathbf{6 g})$ was hydrogenated more slowly than its $N$ phenyl counterpart, whereas no hydrogenation was observed in the case of $N$ benzylidene-tert-butylamine (6h). 
[Table 2]

Next, in order to further study the scope of these catalysts, the hydrogenation of several ketimines with precursor $3 \mathbf{b}(\mathrm{Cl})$ was pursued (Table 3). A series of $\mathrm{N}$-aryl ketimines (7a-f) was reduced with full conversions using a $\mathrm{S} / \mathrm{C} / \mathrm{B}$ ratio of 1000/1/10 (entries 1-6). Under the specified conditions, no differences in reactivity were observed for substrates having electron-donating or -withdrawing substituents at both aryl groups. Also, the naphtyl substituted imine $\mathbf{7 g}$ was hydrogenated with high activity. In contrast, reduction of the thionyl substituted imine $\mathbf{7 h}$ was found to be more sluggish (entry 8). The hydrogenation of $C, C$-dialkyl imine $7 \mathbf{i}$ was tested with complex $\mathbf{3 b}(\mathbf{C l})$, yielding the corresponding amine with good conversion using a S/C ratio of 500 (entry 9). Finally, hydrogenation of the $N$-benzyl imine $7 \mathbf{j}$ was slower than that of its $N$ aryl counterparts since a lower S/C ratio was requiered to get full conversion (entry 10).

[Table 3]

The development of catalytic systems for the (reversible) dehydrogenation of $\mathrm{N}$-heterocycles is gaining considerable interest for applications both in synthesis and $\mathrm{H}_{2}$-storage. ${ }^{[26]}$ Based on the previous results, we were intrigued by the ability of catalysts $\mathbf{3}$ to mediate the hydrogenation/dehydrogenation of $N$-heterocycles. Hence, we have examined the catalytic activity of complexes $3 a(C l)$ and $3 \mathbf{b}(\mathrm{Cl})$ in the hydrogenation of phenanthridine (Scheme 4). ${ }^{[27]}$ This substrate was hydrogenated under 10 bar of $\mathrm{H}_{2}$ at $80{ }^{\circ} \mathrm{C}$ using a $\mathrm{S} / \mathrm{C} / \mathrm{B}=250 / 1 / 10$ with conversions of $94 \%(3 \mathrm{a}(\mathrm{Cl}))$ and $95 \%(3 \mathbf{b}(\mathrm{Cl}))$. Interestingly, the catalytic system derived from $\mathbf{3 b}(\mathrm{Cl})$ efficiently catalyzes the aceptorless dehydrogenation of 5,6-dihydrophenanthridine with complete conversion in refluxing dioxane $(S / C / B=100 / 1 / 10)$. 


\section{Stoichiometric reactions of Ru-CNC complexes}

An important feature of the picolyl-NHC fragment, relevant to metalligand cooperativity, resides in the acidity of the methylene protons. ${ }^{[1 a, 2]}$ Previously, we and others have studied the deprotonation of Ru-CNC species. For example, selective deprotonation with $t \mathrm{BuOK}$ of the methylene arm of the $\mathrm{NHC}$ fragment coordinated trans to the hydrido ligand of fac-complexes $3 a(\mathbf{C l})$ and $\mathbf{3 d}(\mathbf{C l})$ provides derivatives $\mathbf{8 a}$ and $\mathbf{8 d}$, respectively (Scheme 5). ${ }^{[15]}$ Analysis by NMR spectroscopy of complexes 8 clearly shows the dearomatization of the pyridine fragment since significant upfield shifts (4.6-5.5 ppm) are observed for the central ring proton resonances. Similarly, mer-coordinated Ru-CNC complexes react with $t \mathrm{BuOK}$ to yield the corresponding dearomatized/deprotonated derivatives. ${ }^{[11,12]}$

\section{[Scheme 5]}

We hypothesized that ligand-assisted dihydrogen activation by complexes 8 should lead to hydrido species capable of hydrogenating the imine substrates. Hence, upon exposure of a $\left[\mathrm{D}_{8}\right]$ THF solution of $8 \mathbf{a}$ to 3 bar of $\mathrm{H}_{2}$ and subsequent heating at $55{ }^{\circ} \mathrm{C}$ for $1.5 \mathrm{~h}$, derivative $\mathrm{RuH}_{2}(\mathrm{CNC})(\mathrm{CO})$ (9a) was cleanly obtained (Scheme 6). In the ${ }^{1} \mathrm{H}$ NMR spectrum of $9 \mathbf{a}$, the hydrido ligands produce a singlet peak at $-5.7 \mathrm{ppm}$, while signals corresponding to the pyridine fragment appear in the range expected for a rearomatized ring (7.1-7.7 ppm). In addition, resonances produced by the methylene protons appear as two doublets at 5.29 and $5.61 \mathrm{ppm}\left({ }^{2} \mathrm{~J}_{\mathrm{HH}}=13.0 \mathrm{~Hz}\right)$ in agreement with a mer arrangement of the CNC ligand. This coordination mode of the pincer in $9 \mathrm{a}$ is further confirmed by the existence of only one peak for the $\mathrm{C}^{2}-\mathrm{NHC}$ carbon atoms in the ${ }^{13} \mathrm{C}\left\{{ }^{1} \mathrm{H}\right\}$ NMR spectrum at $201.3 \mathrm{ppm}$. The signal corresponding to the CO ligand appears at 214.3 ppm. For comparison, under similar reaction conditions as employed for $\mathbf{9 a}$, mesityl derivative $9 \mathrm{e}$ has been prepared from a suspension of $\mathbf{5 e}\left(\mathbf{B F}_{4}\right)$ in $\left[\mathrm{D}_{8}\right] \mathrm{THF}$ in the presence of $t \mathrm{BuOK}$ (Scheme 6). Complex $9 \mathrm{e}$ has been recently reported by Pidko and coworkers. ${ }^{[12]}$ Spectroscopic features of complexes $\mathbf{9 a}$ and $\mathbf{9 d}$ are very similar. 
[Scheme 6]

Dihydrido complex 9a readily loses $\mathrm{H}_{2}$ when exposed to vacuum, leading to the formation of uncharacterized species. Subsequent heating of the solution at $55^{\circ} \mathrm{C}$ for 15 min under 2.5 bar of $\mathrm{H}_{2}$ regenerates the dihydrido complex. More interestingly, in the ${ }^{1} \mathrm{H},{ }^{1} \mathrm{H}$-EXSY spectrum (mixing time $=0.8 \mathrm{~s}$ ) of $9 \mathrm{e}$ registered at $25{ }^{\circ} \mathrm{C}$ under $\mathrm{H}_{2}$ ( 3 bar) intense exchange cross-peaks are observed between the signal corresponding to $\mathrm{RuH}$ and those of free $\mathrm{H}_{2}$ and both methylene protons. These observations suggest the reversible exchange of free $\mathrm{H}_{2}$ with a $\eta^{2}-\mathrm{H}_{2}$ ligand resulting from the intramolecular protonation of $\mathrm{Ru}-\mathrm{H}$ by protons of the CNC methylene fragment (Scheme 7). ${ }^{[28]}$ In order to determine the participation of complexes $\mathbf{9}$ in the hydrogenation of imines, $\mathrm{N}$ benzylideneaniline $(6 \mathbf{a})$ was added under $\mathrm{H}_{2}$ to a $\left[\mathrm{D}_{8}\right]$ THF solution of $9 \mathbf{a}$ and the reaction was followed by ${ }^{1} \mathrm{H}$ NMR spectroscopy. Immediate disappearance of the $\mathrm{Ru}-\mathrm{H}$ signal of $9 \mathrm{a}$ occurs and two new peaks in the hydride region at -13.14 and $-13.27 \mathrm{ppm}$ in a 1.0:0.2 ratio are observed. Once the imine is hydrogenated to the corresponding amine, the hydrido ligand signal of $9 \mathbf{a}$ is regenerated.

[Scheme 7]

Deprotonated metal-PNP complexes have been shown to exhibit FLPtype reactivity towards small electrophiles such as $\mathrm{CO}_{2}$, carbonyl compounds and nitriles. ${ }^{[5,12]}$ In our case, formation of analogous species with imines may sequester the catalyst and be a catalytic cycle end-off. Generation of these species was studied by addition of $t B u O K$ to a suspension of complex $5 e\left(B_{4}\right)$ and imines $\mathbf{6 a - d}$ in a 1:1 to $1: 1.6$ ratio in $\left[\mathrm{D}_{8}\right]$ THF. NMR analysis of the obtained solutions shows formation of adducts 10 resulting from the addition of the imine to the deprotonated metal-ligand framework with concomitant formation of Ru-N and C-C bonds (Scheme 8). ${ }^{1} \mathrm{H}$ NMR spectra of complexes 10 exhibit singlet signals at ca. $-14 \mathrm{ppm}$ attributable to the hydrido ligands. This chemical shift is close to the value reported by the Milstein's group for amido Ru-PNP complexes $(\delta=-12.8 \mathrm{ppm})$ obtained from the ligand-assisted $\mathrm{N}-\mathrm{H}$ activation of anilines. ${ }^{[29]}$ In addition, the pyridine aromatization in $\mathbf{1 0}$ is inferred from the 
downfield shift of the aromatic protons appearing in the range 7.1-7.5 ppm. More interestingly, the formation of the new carbon-carbon bond is observed from the appearance of two doublets at ca. 5.8 and $4.4 \mathrm{ppm}\left({ }^{3} \mathrm{~J}_{\mathrm{HH}}=5 \mathrm{~Hz}\right)$ corresponding to the methine proton of the pincer and the amido $\mathrm{CHN}-\mathrm{Ru}$ fragment, respectively. The latter value is significantly shifted upfield with respect to the chemical shift of the free imine. ${ }^{[30]}$ Further confirmation of the assignation of this signal was obtained from the existence of an exchange cross-peak in the ${ }^{1} \mathrm{H},{ }^{1} \mathrm{H}$-EXSY spectrum with the signal of the iminic proton of the uncoordinated imine. In addition, ${ }^{13} \mathrm{C}\left\{{ }^{1} \mathrm{H}\right\}$ NMR spectra contain two signals at ca. 64 and $72 \mathrm{ppm}$ attributable to the amido carbon and the methine carbon of the CNC, respectively. Formation of the new bond is further evidenced in the ${ }^{1} \mathrm{H}-{ }^{13} \mathrm{C}$ HMBC experiment by the presence of an intense cross-peak between the $\mathrm{CHN}$ proton of the amido ligand and the methine carbon of the pincer.

[Scheme 8]

Interestingly, addition at room temperature of imine $6 c$ to the adduct $10 a$ gives within minutes a mixture of $10 a$ and $10 c$, leading to further evidence for the reversibility of the formation of the $\mathrm{C}-\mathrm{C}$ and N-Ru bonds. ${ }^{[31]}$ Also, exposing a sample of $10 \mathrm{~b}$ to 3 bar of $\mathrm{H}_{2}$ at $55{ }^{\circ} \mathrm{C}$ for 30 min produces the dihydrido complex $9 \mathbf{e}$ along with the hydrogenation of $\mathbf{6 b}$. Relative thermodynamic stabilities of complexes $\mathbf{1 0}$ have been determined from the equilibria $10+\mathbf{6}^{\prime} \leftrightarrow$ $10^{\prime}+6$ by ${ }^{1} \mathrm{H}$ NMR spectroscopy. From the corresponding ${ }^{298} K_{\text {eq }}$, a stability order of the adducts 10d $>10 a>10 c>10 b$ has been found (see Supplementary Material for details). This trend agrees with the expected electrophilicity of the iminic carbon of the imines, as well as with the better capability of electron-withdrawing groups in the ArN fragment to reduce $d(\pi)$ $p(\pi)$ repulsion between the d-electrons of the metal and the nitrogen electron pair. $^{[32]}$

It is worth mentioning that addition of carbon nucleophiles to coordinated imines to yield amido complexes has been used only very scarcely, ${ }^{[33]}$ and that adducts $\mathbf{1 0}$ represent a rare case of $\mathrm{Ru}(\mathrm{II})$ complexes with labile amido ligands 
with $\beta$-hydrogens, in which the Ru-N bond breaking takes place in the absence of protonation or $\beta$-hydrogen elimination. ${ }^{[34,35]}$

\section{DFT calculations}

DFT calculations (PBE0/6-31g(d,p) + SDD; see Computational Details) were carried out on two model systems. First, a simplified model (denoted by the subscript $\mathrm{Me}$ ) in which the $\mathrm{R}$ substituents of the $\mathrm{CNC}$ ligands are $\mathrm{CH}_{3}$ was used for exploratory calculations. In the second model (denoted by the subscript $\mathrm{Ph}) \mathrm{Ph}$ substituents are placed on the CNC ligand. (E)-N-methylethanimine $\left(\mathbf{6}_{\mathrm{Me}}\right)$ and (E)-N-benzylideneaniline (6a) were chosen as substrates. Fac coordination of the CNC ligand was reproduced in the model complexes $3_{\mathrm{Me}}{ }^{+}$ and $\mathbf{8}_{\mathrm{Me}}$ using $\mathrm{PMe}_{3}$ instead of $\mathrm{PPh}_{3}$. Phosphane dissociation free energy was estimated for the latter to be $17.9 \mathrm{kcal} \cdot \mathrm{mol}^{-1}(\Delta G$-dispersion corrected- in THF). Rearrangement of the CNC ligand coordination mode, from fac to mer, takes place upon phosphane loss from $\mathbf{8}_{\mathbf{M e}}$, and yields a 16 -electron species $\left(\mathbf{A}_{\mathbf{M e}}\right)$, which serves as a model for the dehydrogenated form of the active catalyst. $\mathrm{N}$ methylethanimine coordination to this intermediate yields a model for species 10 , and is calculated to be thermodynamically favourable by $12.3 \mathrm{kcal} \cdot \mathrm{mol}^{-1}$. Similarly, coordination of $N$-methylethanimine or $N$-benzylideneaniline (6a) to $A_{\mathrm{Ph}}$, analogous to $A_{\mathrm{Me}}$, is exergonic by 11.0 and $20.7 \mathrm{kcal} \cdot \mathrm{mol}^{-1}$ respectively. These values are consistent with the formation of $10 a$ from $5 e\left(B_{4}\right)$, tBuOK and $6 \mathbf{a}$, and justify the reversibility of the coordination of imines (see previous section).

According to the calculations, heterolytic $\mathrm{H}_{2}$ cleavage from the $\eta^{2}-\mathrm{H}_{2}$ adduct $\mathbf{A P h}_{\mathrm{Ph}} \cdot \mathbf{H}_{2}$ takes place through a concerted four-membered transition state $\left(\mathrm{TS}_{\mathrm{APh}^{\mathrm{H}} \mathbf{2} \rightarrow \mathbf{9 P h}}\right.$; Figure 7$)$ and has a low energy barrier $(\Delta E)$ of $2.9 \mathrm{kcal} \cdot \mathrm{mol}^{-1}$. ${ }^{[36]}$ The hydrogenation step is energetically favourable, yielding $\mathbf{9}_{\mathbf{P h}}$ with an energy return of $17.0 \mathrm{kcal} \cdot \mathrm{mol}^{-1}$. 
Once species $9_{\mathrm{Ph}}$ is formed, the hydrogenation reaction begins with the formation of a soft complex (or loose pre-complex) between the imine and $9_{\mathrm{Ph}}$ (Figure 8). When the imine is $N$-methylethanimine, a transition state was found for the simultaneous (albeit asynchronous) transfer of two hydrogens, one hydrido ligand and one from a $\mathrm{CH}_{2}$ arm of the $\mathrm{CNC}$ ligand, to the $\mathrm{C}=$ and $=\mathrm{N}$ atoms of the imine linkage respectively. ${ }^{[37]}$ This is a six-membered pericyclic transition state similar to those proposed for related Noyori- and Shvo-type hydrogenation of ketones. ${ }^{[38]}$ This individual step is almost thermoneutral and has an energy barrier of $16.7 \mathrm{kcal} \cdot \mathrm{mol}^{-1}$. The resulting amine forms another soft complex, in this case with the dehydrogenated active form of the catalyst $\mathbf{A}_{\mathrm{Ph}}$, which is broken to liberate the amine and regenerate the catalyst. The calculations show that the overall reaction is exergonic by $3.9 \mathrm{kcal} \cdot \mathrm{mol}^{-1}(\Delta G$ in THF).

[Figure 8]

When the imine is $N$-benzylideneaniline (Figure 9), stepwise hydrogen transfer takes place instead. First, hydride transfer to the $C=$ atom of the soft complex $9_{\mathrm{Ph}}$. imine occurs ${ }^{[38 \mathrm{a}, 39]}$ with an energy barrier of $4.7 \mathrm{kcal} \cdot \mathrm{mol}^{-1}$, to yield an ion-pair $\left(\Delta E=1.3 \mathrm{kcal} \cdot \mathrm{mol}^{-1}\right.$, relative to $9_{\mathrm{Ph}} \cdot$ imine $)$ involving the corresponding cationic Ru complex and benzyl(phenyl)amide anion. This ion pair (B) is further stabilized by $\mathrm{C}-\mathrm{H} \cdots \mathrm{N}(1.87 \AA)$ and $\mathrm{C}-\mathrm{H} \cdots \mathrm{Ru}(2.01 \AA)$ interactions.

[Figure 9]

Following this point, hydrogen transfer from the corresponding $\mathrm{CH}_{2}$ arm of the CNC ligand of $\mathbf{B}$ to the amide nitrogen can occur to generate $\mathrm{N}$ benzylaniline and $\mathbf{A}_{\mathrm{Ph}}$, which may then react with more $\mathrm{H}_{2}$ and imine, to turn over the catalytic cycle. The second hydrogen transfer from $\mathbf{B}$ has a barrier of only $2.7 \mathrm{kcal} \cdot \mathrm{mol}^{-1}$, and is exothermic by $7.7 \mathrm{kcal} \cdot \mathrm{mol}^{-1}$. However, the calculations show that barrier-less coordination of the amide nitrogen of the benzyl(phenyl)amide anion to $\mathrm{Ru}$ to give species $\mathbf{C}$ may be thermodynamically preferred $\left(\Delta G=-14.2 \mathrm{kcal} \cdot \mathrm{mol}^{-1}\right.$ from $\left.\mathbf{B}\right)$ to formation of $A_{p h}+$ benzylaniline 
$\left(\Delta G=-9.6 \mathrm{kcal} \cdot \mathrm{mol}^{-1}\right) . \mathrm{N}$-coordination of an intermediate amide to $\mathrm{Ru}$ to give stable species could account for the hydride resonances seen by NMR in the reaction of $9 \mathbf{a}$ and $\mathbf{6 a}$, but according to the results of the calculations described to this point, it would represent a thermodynamic sink that may halt the catalysis. Alternatively, Dub, Gordon et al. ${ }^{[40]}$ as well as Pidko et al. ${ }^{[5,6 i]}$ have recently proposed a role for the coordination of a second molecule of hydrogen to Ru prior to a second hydrogen transfer in related asymmetric hydrogenation of ketones and $\mathrm{CO}_{2}$ hydrogenation respectively (Figure 10), albeit in those reactions, higher $\mathrm{H}_{2}$ pressures than in this work were used. In this case, cleavage of the $\mathrm{C}-\mathrm{H} \cdots \mathrm{Ru}$ interaction and $\mathrm{H}_{2}$ coordination to $\mathrm{Ru}$ in $\mathbf{B}$ is exothermic by $0.9 \mathrm{kcal} \cdot \mathrm{mol}^{-1}$ (and endergonic by only $5.1 \mathrm{kcal} \cdot \mathrm{mol}^{-1}$ ). The second hydrogen transfer from the new ion pair (D) may then occur from the coordinated $\mathrm{H}_{2}$, which according to a Relaxed Potential Energy Surface Scan may be barrier-less (no transition state was located for this transformation) yielding benzylaniline and $9 \mathrm{Ph}$, with $\Delta G=-20.6 \mathrm{kcal} \cdot \mathrm{mol}^{-1}$, and closing the catalytic cycle. These results, summarized in the free energy profile depicted in Scheme 9, suggest that both stepwise pathways may compete in the catalytic hydrogenation of imines by the Ru-CNC pincer complexes of this work. However, the relative stability of intermediate $\mathbf{C}$ (which may map onto hydride intermediates detected in the reaction of $9 \mathbf{a}$ and $\mathbf{6 a}$ ), support the mechanism in which the imide intermediate $\mathbf{B}$ is protonated by a second dihydrogen molecule coordinated to $\mathrm{Ru}$.

[Figure 10]

[Scheme 9]

\section{Conclusions}

A series of new ruthenium complexes $\mathbf{3}$ incorporating neutral dicarbene CNC ligands have been prepared by reaction of silver complexes 2 and $\mathrm{RuHCl}(\mathrm{CO})\left(\mathrm{PPh}_{3}\right)_{3}$. Contrary to previously observed meridional coordination of analogous CNC ligands, complexes 3 exhibit a fac coordination mode for the 
pincer. Derivatives 3, in the presence of $t \mathrm{BuOK}$, catalyze the hydrogenation of $\mathrm{C}=\mathrm{N}$ bonds of imines and phenanthridine with $\mathrm{S} / \mathrm{C}$ ratios of up to 1000 . Mechanistic insight has been obtained from the NMR study of several derivatives including deprotonated complexes $\mathbf{8}$, dihydrido derivatives $\mathbf{9}$ and imine adducts 10. In addition, DFT calculations show that stepwise hydrogen transfer, initiated by outer-sphere hydride transfer with formation of ion pairs, may account for the addition of $\mathrm{H}_{2}$ to the imines.

\section{Experimental and Computational Methods}

General Procedures. All reactions and manipulations were performed under nitrogen or argon, either in a Braun Labmaster 100 glovebox or using standard Schlenk-type techniques. All solvents were distilled under nitrogen with the following desiccants: sodium-benzophenone-ketyl for diethyl ether $\left(\mathrm{Et}_{2} \mathrm{O}\right)$ and tetrahydrofuran (THF, $\left[\mathrm{D}_{8}\right] \mathrm{THF}$ ); sodium for hexane and toluene; $\mathrm{CaH}_{2}$ for dichloromethane and acetonitrile $\left(\mathrm{CH}_{2} \mathrm{Cl}_{2}, \mathrm{CH}_{3} \mathrm{CN}, \mathrm{CD}_{3} \mathrm{CN}\right)$; and $\mathrm{NaOMe}$ for methanol $(\mathrm{MeOH})$. Imidazolium salts $\mathbf{1}$ and silver complexes 2 were prepared as specified in the Supplementary Material. $\mathrm{RuHCl}(\mathrm{CO})\left(\mathrm{PPh}_{3}\right)_{3}$ was synthesized according to a literature procedure. ${ }^{[41]}$ Syntheses of imines 7 were effected following literature methods (see Supplementary Material). All other reagents were purchased from commercial suppliers and used as received. NMR spectra were obtained on a Bruker DPX-300, DRX-400, AVANCEIII/ASCEND 400R, or DRX-500 spectrometers. ${ }^{13} \mathrm{C}\left\{{ }^{1} \mathrm{H}\right\}$ and ${ }^{1} \mathrm{H}$ shifts were referenced to the residual signals of deuterated solvents. ${ }^{31} \mathrm{P}\left\{{ }^{1} \mathrm{H}\right\}$ and ${ }^{19} \mathrm{~F}\left\{{ }^{1} \mathrm{H}\right\}$ NMR shifts were referenced to external $85 \% \mathrm{H}_{3} \mathrm{PO}_{4}$ and $\mathrm{CFCl}_{3}$, respectively. All data are reported in ppm downfield from $\mathrm{Me}_{4} \mathrm{Si}$. All NMR measurements were carried out at $25^{\circ} \mathrm{C}$, unless otherwise stated. GC-MS analyses were performed on a Shimadzu GCMSQP2010-Plus apparatus equipped with a ZB-5MS capillary column (10 $\mathrm{m}, 0.18 \mathrm{~mm}$ i.d., $0.18 \mu \mathrm{m}$ film thickness). HRMS data were obtained on a JEOL JMS-SX 102A mass spectrometer at the Instrumental Services of Universidad de Sevilla (CITIUS). ESI-MS experiments were carried out in a Bruker 6000 apparatus by the Mass Spectrometry Service of the Instituto de Investigaciones 
Químicas. Elemental analyses were run by the Analytical Service of the Instituto de Investigaciones Químicas in a Leco TruSpec CNH elemental analyzer. IR spectra were acquired on a Bruker Tensor 27 instrument.

X-Ray structure analysis. CCDC-1027679 [2a(Br)], 1027680 [2d(Cl) $\left.\cdot 2 \mathrm{CHCl}_{3}\right]$, $1027681\left[4 \mathrm{e} \cdot \mathrm{CH}_{2} \mathrm{Cl}_{2}\right]$ and $1044008\left[\mathbf{5 d}\left(\mathrm{BF}_{4}\right) \cdot \mathrm{C}_{7} \mathrm{H}_{8}\right]$ contain the supplementary crystallographic data for this paper. These data can be obtained free of charge from The Cambridge Crystallographic Data Centre via http://www.ccdc.cam.ac.uk/data_request/cif.

Computational details. Calculations were carried out at the DFT level using the Gaussian 09 program ${ }^{[42]}$ with the PBE0 functional. ${ }^{[33]}$ All atoms were represented with the $6-31 \mathrm{~g}(\mathrm{~d}, \mathrm{p})$ basis set, ${ }^{[44]}$ except $\mathrm{Ru}$, for which the Stuttgart/Dresden Effective Core Potential and its associated basis set SDD ${ }^{[45]}$ was used. All geometry optimizations were performed in the gas phase without restrictions. Vibrational analysis was used to characterize the stationary points in the potential energy surface, as well as for calculating the Zero-point, Enthalpy and Gibbs energy corrections at $295 \mathrm{~K}$ and $1 \mathrm{~atm}$. The nature of the intermediates connected by a given transition state along a reaction path was proven by IRC calculations or by perturbing the geometry of the TS along the reaction path eigenvector. Bulk solvent effects were modelled with the SMD continuum model. ${ }^{[46]}$

\section{Synthesis of Ru-CNC complexes 3-5}

Complex $3 \mathrm{a}(\mathrm{Cl})$ : A mixture of silver complex $2 \mathrm{a}(\mathrm{Cl})(0.150 \mathrm{~g}, 0.25 \mathrm{mmol})$ and $\mathrm{RuHCl}(\mathrm{CO})\left(\mathrm{PPh}_{3}\right)_{3}(0.234 \mathrm{~g}, 0.25 \mathrm{mmol})$ in THF $(8 \mathrm{~mL})$ was heated at $55^{\circ} \mathrm{C}$ for $24 \mathrm{~h}$. The resulting solution was filtered, brought to dryness and extracted with $\mathrm{MeOH}(2 \times 5 \mathrm{~mL})$. Solvent was evaporated and the obtained solid was recrystallized from $\mathrm{MeOH} /$ toluene. Yellow solid (0.120 g, 65\%). ${ }^{1} \mathrm{H}$ NMR (400 $\mathrm{MHz}, \mathrm{CD}_{2} \mathrm{Cl}_{2}$ ): $\delta=8.05$ (s, $1 \mathrm{H} ; \mathrm{H}$ imid), 7.89 (s, $1 \mathrm{H} ; \mathrm{H}$ imid), 7.49 (s, $1 \mathrm{H} ; \mathrm{H}$ imid), $7.15\left(\mathrm{~m}, 18 \mathrm{H} ; 15 \mathrm{H}\right.$ arom $\mathrm{PPh}_{3}+2 \mathrm{H}-3$ py $\left.+\mathrm{H}-4 \mathrm{py}\right), 7.01$ (s, $1 \mathrm{H} ; \mathrm{H}$ imid), $5.91\left(\mathrm{~d},{ }^{2} \mathrm{~J}(\mathrm{H}, \mathrm{H})=14.0 \mathrm{~Hz}, 1 \mathrm{H}\right.$; py-CHH), $5.82\left(\mathrm{~d},{ }^{2} \mathrm{~J}(\mathrm{H}, \mathrm{H})=15.5 \mathrm{~Hz}, 1 \mathrm{H} ;\right.$ py- 
$\mathrm{CHH}), 5.71\left(\mathrm{~d},{ }^{2} \mathrm{~J}(\mathrm{H}, \mathrm{H})=14.0 \mathrm{~Hz}, 1 \mathrm{H} ;\right.$ py-CHH), $5.44\left(\mathrm{~h},{ }^{3} \mathrm{~J}(\mathrm{H}, \mathrm{H})=6.5 \mathrm{~Hz}, 1 \mathrm{H}\right.$; $\left.\mathrm{CH}\left(\mathrm{CH}_{3}\right)_{2}\right), 5.04\left(\mathrm{~h},{ }^{3} \mathrm{~J}(\mathrm{H}, \mathrm{H})=6.5 \mathrm{~Hz}, 1 \mathrm{H} ; \mathrm{CH}\left(\mathrm{CH}_{3}\right)_{2}\right), 4.29\left(\mathrm{~d},{ }^{2} \mathrm{~J}(\mathrm{H}, \mathrm{H})=15.5\right.$ $\mathrm{Hz}, 1 \mathrm{H}$; py-CHH), $1.61\left(\mathrm{~d},{ }^{3} \mathrm{~J}(\mathrm{H}, \mathrm{H})=6.5 \mathrm{~Hz}, 3 \mathrm{H} ; \mathrm{CH}_{3}\right), 1.59\left(\mathrm{~d},{ }^{3} \mathrm{~J}(\mathrm{H}, \mathrm{H})=6.5 \mathrm{~Hz}\right.$, $\left.3 \mathrm{H} ; \mathrm{CH}_{3}\right), 1.30\left(\mathrm{~d},{ }^{3} \mathrm{~J}(\mathrm{H}, \mathrm{H})=6.5 \mathrm{~Hz}, 3 \mathrm{H} ; \mathrm{CH}_{3}\right), 1.22\left(\mathrm{~d},{ }^{3} \mathrm{~J}(\mathrm{H}, \mathrm{H})=6.5 \mathrm{~Hz}, 3 \mathrm{H}\right.$; $\left.\mathrm{CH}_{3}\right),-7.30 \mathrm{ppm}\left(\mathrm{d},{ }^{2} \mathrm{~J}(\mathrm{H}, \mathrm{P})=30.5 \mathrm{~Hz}, 1 \mathrm{H}\right.$; RuH); ${ }^{31} \mathrm{P}\left\{{ }^{1} \mathrm{H}\right\} \mathrm{NMR}(202 \mathrm{MHz}$, $\left.\mathrm{CD}_{2} \mathrm{Cl}_{2}\right): \delta=42.4 \mathrm{ppm} ;{ }^{13} \mathrm{C}\left\{{ }^{1} \mathrm{H}\right\} \mathrm{NMR}\left(126 \mathrm{MHz}, \mathrm{CD}_{2} \mathrm{Cl}_{2}\right): \delta=209.2\left(\mathrm{~d},{ }^{2} \mathrm{~J}(\mathrm{C}, \mathrm{P})\right.$ $=15 \mathrm{~Hz}$; CO), 189.0 (d, ${ }^{2} \mathrm{~J}(\mathrm{C}, \mathrm{P})=7 \mathrm{~Hz}$; C-2 imid), $181.5\left(\mathrm{~d},{ }^{2} \mathrm{~J}(\mathrm{C}, \mathrm{P})=81 \mathrm{~Hz}\right.$; C2 imid), 157.0 (C-2 py), 156.9 (C-2 py), 138.7 (C-4 py), 136.7 (br d, ${ }^{1} J(C, P)=39$ $\mathrm{Hz}$; $3 \mathrm{C}_{\mathrm{q}}$ arom, $\mathrm{PPh}_{3}$ ), $133.2\left(\mathrm{~d},{ }^{2} \mathrm{~J}(\mathrm{C}, \mathrm{P})=11 \mathrm{~Hz} ; 6 \mathrm{CH}\right.$ arom, $\left.\mathrm{PPh}_{3}\right), 129.9$ (3 $\mathrm{CH}$ arom, $\mathrm{PPh}_{3}$ ), 128.5 (d, ${ }^{4} \mathrm{~J}(\mathrm{C}, \mathrm{P})=9 \mathrm{~Hz} ; 6 \mathrm{CH}$ arom, $\mathrm{PPh}_{3}$ ), 125.1 (C-3 py), 125.0 (C-3 py), 124.6 ( $\mathrm{CH}$ imid), 123.5 ( $\mathrm{CH}$ imid), 117.8 ( $\mathrm{CH}$ imid), $116.7(\mathrm{CH}$ imid), 58.5 (py- $\left.\mathrm{CH}_{2}\right), 55.6$ (py- $\left.\mathrm{CH}_{2}\right), 52.3\left(\mathrm{CH}\left(\mathrm{CH}_{3}\right)_{2}\right), 51.7\left(\mathrm{CH}\left(\mathrm{CH}_{3}\right)_{2}\right), 24.9$ $\left(\mathrm{CH}_{3}\right), 25.0\left(\mathrm{CH}_{3}\right), 24.2\left(2 \mathrm{CH}_{3}\right), 23.0$ ppm $\left(\mathrm{CH}_{3}\right) ; \mathrm{IR}$ (Nujol): $v=1921,1878$, $1840 \mathrm{~cm}^{-1}$ (RuH, CO); MS (ESI, DMSO/MeCN): $\mathrm{m} / z$ (\%): 716 (100) [(M-Cl) $\left.{ }^{+}\right]$. Fragmentation of ion $\mathrm{m} / \mathrm{z}=716: 454(100)\left[\left(\mathrm{M}-\mathrm{Cl}-\mathrm{PPh}_{3}\right)^{+}\right]$; elemental analysis calcd (\%) for $\mathrm{C}_{38} \mathrm{H}_{41} \mathrm{CIN}_{5} \mathrm{OPRu}$ : C 60.75, H 5.50, N 9.32; found: C 60.66, $\mathrm{H}$ 5.68, N 9.35 .

Complex $3 \mathrm{a}\left(\mathrm{BF}_{4}\right)$ : A mixture of silver complex $\mathbf{2 a}(\mathrm{Br})(0.050 \mathrm{~g}, 0.07 \mathrm{mmol})$ and $\mathrm{RuHCl}(\mathrm{CO})\left(\mathrm{PPh}_{3}\right)_{3}(0.068 \mathrm{~g}, 0.07 \mathrm{mmol})$ in THF $(2 \mathrm{~mL})$ was heated at $55{ }^{\circ} \mathrm{C}$ for $16 \mathrm{~h}$. The resulting solution was filtered, brought to dryness and extracted with $\mathrm{MeOH}(2 \times 2 \mathrm{~mL})$. Solvent was removed, and the obtained solid was dissolved in $\mathrm{CH}_{2} \mathrm{Cl}_{2}(2 \mathrm{~mL})$ and treated with $\mathrm{NaBF}_{4}(0.008 \mathrm{~g}, 0.07 \mathrm{mmol})$ for $16 \mathrm{~h}$. The resulting mixture was filtered through a short pad of Celite, and solvent was evaporated. Complex $3 a\left(\mathrm{BF}_{4}\right)$ was isolated as a yellow solid after recrystallization from $\mathrm{CH}_{2} \mathrm{Cl}_{2} / \mathrm{Et}_{2} \mathrm{O}(0.037 \mathrm{~g}, 65 \%)$. ${ }^{1} \mathrm{H} \mathrm{NMR}(400 \mathrm{MHz}$, $\left.\left[\mathrm{D}_{6}\right] \mathrm{DMSO}\right): \delta=7.86\left(\mathrm{t},{ }^{3} \mathrm{~J}(\mathrm{H}, \mathrm{H})=7.6 \mathrm{~Hz}, 1 \mathrm{H} ; \mathrm{H}-4 \mathrm{py}\right), 7.66(\mathrm{~m}, 2 \mathrm{H} ; \mathrm{H}$ imid $+\mathrm{H}-$ 3 py), $7.61\left(\mathrm{~d},{ }^{3} \mathrm{~J}(\mathrm{H}, \mathrm{H})=1.6 \mathrm{~Hz}, 1 \mathrm{H} ; \mathrm{H}\right.$ imid), $7.51\left(\mathrm{~d},{ }^{3} \mathrm{~J}(\mathrm{H}, \mathrm{H})=1.6 \mathrm{~Hz}, 1 \mathrm{H} ; \mathrm{H}\right.$ imid), $7.46\left(\mathrm{~d},{ }^{3} \mathrm{~J}(\mathrm{H}, \mathrm{H})=2.0 \mathrm{~Hz}, 1 \mathrm{H} ; \mathrm{H}\right.$ imid), $7.28\left(\mathrm{t},{ }^{3} \mathrm{~J}(\mathrm{H}, \mathrm{H})=7.6 \mathrm{~Hz}, 3 \mathrm{H} ; 3 \mathrm{H}\right.$ arom, $\left.\mathrm{PPh}_{3}\right), 7.20\left(\mathrm{t},{ }^{3} \mathrm{~J}(\mathrm{H}, \mathrm{H})=7.6 \mathrm{~Hz}, 6 \mathrm{H} ; 6 \mathrm{H}\right.$ arom, $\left.\mathrm{PPh}_{3}\right), 7.14\left(\mathrm{~d},{ }^{3} \mathrm{~J}(\mathrm{H}, \mathrm{H})=\right.$ $7.2 \mathrm{~Hz}, 1 \mathrm{H} ; \mathrm{H}-3 \mathrm{py}), 7.06\left(\mathrm{dd},{ }^{3} \mathrm{~J}(\mathrm{H}, \mathrm{P})=9.2 \mathrm{~Hz},{ }^{3} \mathrm{~J}(\mathrm{H}, \mathrm{H})=9.2 \mathrm{~Hz}, 6 \mathrm{H} ; 6 \mathrm{H}\right.$ arom, $\left.\mathrm{PPh}_{3}\right), 5.67\left(\mathrm{~d},{ }^{2} \mathrm{~J}(\mathrm{H}, \mathrm{H})=14.4 \mathrm{~Hz}, 1 \mathrm{H}\right.$; py-CHH), $5.56\left(\mathrm{~d},{ }^{2} \mathrm{~J}(\mathrm{H}, \mathrm{H})=13.6 \mathrm{~Hz}, 1 \mathrm{H}\right.$; py-CHH), $5.31\left(\mathrm{~h},{ }^{3} \mathrm{~J}(\mathrm{H}, \mathrm{H})=6.4 \mathrm{~Hz}, 1 \mathrm{H} ; \mathrm{CH}\left(\mathrm{CH}_{3}\right)_{2}\right), 5.25\left(\mathrm{~d},{ }^{2} \mathrm{~J}(\mathrm{H}, \mathrm{H})=15.6 \mathrm{~Hz}\right.$, 
$1 \mathrm{H}$; py-CHH), $4.94\left(\mathrm{~h},{ }^{3} \mathrm{~J}(\mathrm{H}, \mathrm{H})=6.4 \mathrm{~Hz}, 1 \mathrm{H} ; \mathrm{CH}\left(\mathrm{CH}_{3}\right)_{2}\right), 4.18\left(\mathrm{~d},{ }^{2} \mathrm{~J}(\mathrm{H}, \mathrm{H})=15.2\right.$ $\mathrm{Hz}, 1 \mathrm{H} ; \mathrm{py}-\mathrm{CH}), 1.57\left(\mathrm{~d},{ }^{3} \mathrm{~J}(\mathrm{H}, \mathrm{H})=6.8 \mathrm{~Hz}, 3 \mathrm{H} ; \mathrm{CH}_{3}\right), 1.48\left(\mathrm{~d},{ }^{3} \mathrm{~J}(\mathrm{H}, \mathrm{H})=6.4 \mathrm{~Hz}\right.$, $\left.3 \mathrm{H} ; \mathrm{CH}_{3}\right), 1.29\left(\mathrm{~d},{ }^{3} \mathrm{~J}(\mathrm{H}, \mathrm{H})=6.8 \mathrm{~Hz}, 3 \mathrm{H} ; \mathrm{CH}_{3}\right), 1.20\left(\mathrm{~d},{ }^{3} \mathrm{~J}(\mathrm{H}, \mathrm{H})=6.4 \mathrm{~Hz}, 3 \mathrm{H}\right.$; $\left.\mathrm{CH}_{3}\right),-7.38 \mathrm{ppm}\left(\mathrm{d},{ }^{2} \mathrm{~J}(\mathrm{H}, \mathrm{P})=30.4 \mathrm{~Hz}, 1 \mathrm{H}\right.$; RuH $) ;{ }^{31} \mathrm{P}\left\{{ }^{1} \mathrm{H}\right\} \mathrm{NMR}(162 \mathrm{MHz}$, [D $\mathrm{D}_{6}$ DMSO): $\delta=42.9 \mathrm{ppm} ;{ }^{13} \mathrm{C}\left\{{ }^{1} \mathrm{H}\right\} \mathrm{NMR}\left(101 \mathrm{MHz},\left[\mathrm{D}_{6}\right] \mathrm{DMSO}\right): \delta=209.5$ (d, ${ }^{2} J(C, P)=15 \mathrm{~Hz}$; CO), $187.9\left(\mathrm{~d},{ }^{2} \mathrm{~J}(\mathrm{C}, \mathrm{P})=8 \mathrm{~Hz}\right.$; C-2 imid), $180.4\left(\mathrm{~d},{ }^{2} \mathrm{~J}(\mathrm{C}, \mathrm{P})=81\right.$ Hz; C-2 imid), 157.6 (C-2 py), 156.6 (C-2 py), 140.5 (C-4 py), 136.7 (br d, ${ }^{1} \mathrm{~J}(\mathrm{C}, \mathrm{P})=40 \mathrm{~Hz} ; 3 \mathrm{C}_{\mathrm{q}}$ arom, $\left.\mathrm{PPh}_{3}\right), 133.3\left(\mathrm{~d},{ }^{3} \mathrm{~J}(\mathrm{C}, \mathrm{P})=11 \mathrm{~Hz} ; 6 \mathrm{CH}\right.$ arom, $\left.\mathrm{PPh}_{3}\right), 130.5$ (3 CH arom, $\left.\mathrm{PPh}_{3}\right), 129.1$ (d, ${ }^{4} \mathrm{~J}(\mathrm{C}, \mathrm{P})=9 \mathrm{~Hz} ; 6 \mathrm{CH}$ arom, $\mathrm{PPh}_{3}$ ), 125.4 (C-3 py), 125.2 (C-3 py), 124.7 ( $\mathrm{CH}$ imid), 123.8 (CH imid), $120.0(\mathrm{CH}$ imid), 118.7 ( $\mathrm{CH}$ imid), 58.5 (py- $\left.\mathrm{CH}_{2}\right), 55.8\left(\right.$ py- $\left.\mathrm{CH}_{2}\right), 52.7\left(\mathrm{CH}\left(\mathrm{CH}_{3}\right)_{2}\right), 51.9$ $\left(\mathrm{CH}\left(\mathrm{CH}_{3}\right)_{2}\right), 24.9\left(\mathrm{CH}_{3}\right), 24.7\left(\mathrm{CH}_{3}\right), 24.2\left(\mathrm{CH}_{3}\right), 23.2 \mathrm{ppm}\left(\mathrm{CH}_{3}\right)$; IR (Nujol): $v=$ 1909, 1878, $1840 \mathrm{~cm}^{-1}$ (CO, RuH); HRMS (FAB): $\mathrm{m} / z: 716.2108\left[\left(M-B F_{4}\right)^{+}\right]$, exact mass calculated for $\mathrm{C}_{38} \mathrm{H}_{41} \mathrm{~N}_{5} \mathrm{OPRu}$ : 716.2029.

Complex $\mathbf{3 b}(\mathrm{Cl})$ : This complex was prepared as described for $\mathbf{3 a}(\mathrm{Cl})$. Yellow solid (0.056 g, 47\%). ${ }^{1} \mathrm{H}$ NMR (400 MHz, $\left.\mathrm{CD}_{2} \mathrm{Cl}_{2}\right): \delta=7.96\left(\mathrm{~d},{ }^{3} \mathrm{~J}(\mathrm{H}, \mathrm{H})=1.6 \mathrm{~Hz}\right.$, $1 \mathrm{H}$; $\mathrm{H}$ imid), 7.85 (br s, $1 \mathrm{H} ; \mathrm{H}$ imid), 7.53 (t, ${ }^{3} \mathrm{~J}(\mathrm{H}, \mathrm{H})=4.4 \mathrm{~Hz}, 1 \mathrm{H} ; \mathrm{H}-4$ py), 7.19-7.29 (m, 17H; $15 \mathrm{H}$ arom $\left.\mathrm{PPh}_{3}+2 \mathrm{H}-4 \mathrm{py}\right), 7.08\left(\mathrm{~d},{ }^{3} \mathrm{~J}(\mathrm{H}, \mathrm{H})=1.6 \mathrm{~Hz}, 1 \mathrm{H}\right.$; $\mathrm{H}$ imid), 6.95 (br s, $1 \mathrm{H} ; \mathrm{H}$ imid), $5.95\left(\mathrm{~d},{ }^{2} \mathrm{~J}(\mathrm{H}, \mathrm{H})=14.0 \mathrm{~Hz}, 1 \mathrm{H}\right.$; py-CHH), 5.76 $\left(\mathrm{m}, 2 \mathrm{H} ; 2\right.$ py-CHH), $4.75(\mathrm{~m}, 1 \mathrm{H} ; \mathrm{CH}), 4.41(\mathrm{~m}, 1 \mathrm{H} ; \mathrm{CH}), 4.26\left(\mathrm{~d},{ }^{2} \mathrm{~J}(\mathrm{H}, \mathrm{H})=\right.$ $15.2 \mathrm{~Hz}, 1 \mathrm{H}$; py-CHH), $4.06(\mathrm{~m}, 2 \mathrm{H} ; 2 \mathrm{CH}), 1.74\left(\mathrm{~m}, 4 \mathrm{H} ; 2 \mathrm{CH}_{2}\right), 1.36(\mathrm{~m}, 12 \mathrm{H}$; $\left.6 \mathrm{CH}_{2}\right), 0.87\left(\mathrm{~m}, 6 \mathrm{H} ; 2 \mathrm{CH}_{3}\right),-7.14 \mathrm{ppm}\left(\mathrm{d},{ }^{2} J(\mathrm{H}, \mathrm{P})=28.8 \mathrm{~Hz}, 1 \mathrm{H} ; \mathrm{RuH}\right)$; ${ }^{31} \mathrm{P}\left\{{ }^{1} \mathrm{H}\right\} \operatorname{NMR}\left(162 \mathrm{MHz}, \mathrm{CD}_{2} \mathrm{Cl}_{2}\right): \delta=43.3 \mathrm{ppm} ;{ }^{13} \mathrm{C}\left\{{ }^{1} \mathrm{H}\right\} \mathrm{NMR}(101 \mathrm{MHz}$, $\left.\mathrm{CD}_{2} \mathrm{Cl}_{2}\right): \delta=209.4\left(\mathrm{~d},{ }^{2} \mathrm{~J}(\mathrm{C}, \mathrm{P})=15 \mathrm{~Hz} ; \mathrm{CO}\right), 189.9\left(\mathrm{~d},{ }^{2} \mathrm{~J}(\mathrm{C}, \mathrm{P})=8 \mathrm{~Hz} ; \mathrm{C}-2 \mathrm{imid}\right)$, $182.3\left(\mathrm{~d},{ }^{2} \mathrm{~J}(\mathrm{C}, \mathrm{P})=81 \mathrm{~Hz}\right.$; C-2 imid), 157.1 (2 C-2 py), 138.6 (C-4 py), 136.6 (d, ${ }^{1} \mathrm{~J}(\mathrm{C}, \mathrm{P})=39 \mathrm{~Hz} ; 3 \mathrm{C}_{\mathrm{q}}$ arom, $\left.\mathrm{PPh}_{3}\right), 133.1\left(\mathrm{~d},{ }^{3} \mathrm{~J}(\mathrm{C}, \mathrm{P})=10 \mathrm{~Hz} ; 6 \mathrm{CH}\right.$ arom, $\left.\mathrm{PPh}_{3}\right), 129.8$ (3 CH arom, $\left.\mathrm{PPh}_{3}\right), 128.4\left(\mathrm{~d},{ }^{4} \mathrm{~J}(\mathrm{C}, \mathrm{P})=8 \mathrm{~Hz} ; 6 \mathrm{CH}\right.$ arom, $\left.\mathrm{PPh}_{3}\right)$, 125.0 (C-3 py), 124.5 ( $\mathrm{CH}$ imid + C-3 py), 122.8 ( $\mathrm{CH}$ imid), $121.2(\mathrm{CH}$ imid), 120.2 ( $\mathrm{CH}$ imid), 58.6 (py- $\left.\mathrm{CH}_{2}\right), 55.6\left(\right.$ py- $\left.\mathrm{CH}_{2}\right), 51.7\left(\mathrm{CH}_{2}\right), 50.7\left(\mathrm{CH}_{2}\right), 31.9$ $\left(\mathrm{CH}_{2}\right), 31.7\left(2 \mathrm{CH}_{2}\right), 31.2\left(\mathrm{CH}_{2}\right), 26.9\left(\mathrm{CH}_{2}\right), 26.7\left(\mathrm{CH}_{2}\right), 22.8\left(2 \mathrm{CH}_{2}\right), 14.0 \mathrm{ppm}$ $\left(2 \mathrm{CH}_{3}\right)$; IR $\left(\mathrm{CH}_{2} \mathrm{Cl}_{2}\right): v=1924 \mathrm{~cm}^{-1}(\mathrm{CO})$; MS (ESI, DMSO/MeOH): $\mathrm{m} / z(\%)$ : $800(100)\left[(\mathrm{M}-\mathrm{Cl})^{+}\right]$. Fragmentation of ion $\mathrm{m} / \mathrm{z}=800: 538(100)\left[\left(\mathrm{M}-\mathrm{Cl}-\mathrm{PPh}_{3}\right)^{+}\right]$; 
elemental analysis calcd (\%) for $\mathrm{C}_{44} \mathrm{H}_{53} \mathrm{CIN}_{5} \mathrm{OPRu}$ : C 63.26, $\mathrm{H}$ 6.39, N 8.38; found: C 63.25, H 6.39, N 8.34.

Complex 3c(Br): A mixture of silver complex $\mathbf{2 c}(\mathrm{Br})(0.175 \mathrm{~g}, 0.23 \mathrm{mmol})$ and $\mathrm{RuHCl}(\mathrm{CO})\left(\mathrm{PPh}_{3}\right)_{3}(0.233 \mathrm{~g}, 0.23 \mathrm{mmol})$ in THF $(8 \mathrm{~mL})$ was heated at $55^{\circ} \mathrm{C}$ for $24 \mathrm{~h}$. The resulting solution was filtered, brought to dryness and extracted with $\mathrm{MeOH}(3 \times 5 \mathrm{~mL})$. Solvent was evaporated, and the residue was dissolved in THF and treated with $\mathrm{NaBr}(0.023 \mathrm{~g}, 0.23 \mathrm{mmol})$ for $24 \mathrm{~h}$. Solvent was removed under vacuum, and the solid was extracted in $\mathrm{CH}_{2} \mathrm{Cl}_{2}(3 \times 5 \mathrm{~mL})$. The resulting solution was brought to dryness, and the solid was recrystallized from $\mathrm{MeOH} /$ toluene. Yellow solid (0.042 g, 22\%). ${ }^{1} \mathrm{H}$ NMR $\left(500 \mathrm{MHz}, \mathrm{CD}_{2} \mathrm{Cl}_{2}\right): \delta=$ $8.07\left(\mathrm{~d},{ }^{3} \mathrm{~J}(\mathrm{H}, \mathrm{H})=1.6 \mathrm{~Hz}, 1 \mathrm{H} ; \mathrm{H}\right.$ imid), $7.85\left(\mathrm{~d},{ }^{3} \mathrm{~J}(\mathrm{H}, \mathrm{H})=1.6 \mathrm{~Hz}, 1 \mathrm{H} ; \mathrm{H}\right.$ imid), $7.39\left(\mathrm{~d},{ }^{3} \mathrm{~J}(\mathrm{H}, \mathrm{H})=7.5 \mathrm{~Hz}, 1 \mathrm{H} ; \mathrm{H}-3 \mathrm{py}\right), 7.26\left(\mathrm{~m}, 9 \mathrm{H} ; 9 \mathrm{H}\right.$ arom, $\left.\mathrm{PPh}_{3}\right), 7.23(\mathrm{~d}$, ${ }^{3} \mathrm{~J}(\mathrm{H}, \mathrm{H})=1.6 \mathrm{~Hz}, 1 \mathrm{H} ; \mathrm{H}$ imid), $7.17\left(\mathrm{dd},{ }^{3} \mathrm{~J}(\mathrm{H}, \mathrm{P})=8.0 \mathrm{~Hz},{ }^{3} \mathrm{~J}(\mathrm{H}, \mathrm{H})=8.0 \mathrm{~Hz}, 6 \mathrm{H}\right.$; $6 \mathrm{H}$ arom, $\left.\mathrm{PPh}_{3}\right), 7.12\left(\mathrm{~d},{ }^{3} \mathrm{~J}(\mathrm{H}, \mathrm{H})=8.5 \mathrm{~Hz}, 1 \mathrm{H} ; \mathrm{H}-3 \mathrm{py}\right), 7.07\left(\mathrm{t},{ }^{3} \mathrm{~J}(\mathrm{H}, \mathrm{H})=6.5\right.$ $\mathrm{Hz}, 1 \mathrm{H} ; \mathrm{H}-4$ py), 7.05 (d, ${ }^{3} \mathrm{~J}(\mathrm{H}, \mathrm{H})=1.6 \mathrm{~Hz}, 1 \mathrm{H} ; \mathrm{H}$ imid), $5.85\left(\mathrm{~d},{ }^{2} \mathrm{~J}(\mathrm{H}, \mathrm{H})=14.0\right.$ $\mathrm{Hz}, 1 \mathrm{H}$; py-CHH), $5.73\left(\mathrm{~d},{ }^{2} \mathrm{~J}(\mathrm{H}, \mathrm{H})=15.0 \mathrm{~Hz}, 1 \mathrm{H} ; \mathrm{py}-\mathrm{CHH}\right), 5.47\left(\mathrm{~d},{ }^{2} \mathrm{~J}(\mathrm{H}, \mathrm{H})=\right.$ $14.0 \mathrm{~Hz}, 1 \mathrm{H}$; py-CHH), $5.12\left(\mathrm{~d},{ }^{2} \mathrm{~J}(\mathrm{H}, \mathrm{H})=13.5 \mathrm{~Hz}, 1 \mathrm{H} ; \mathrm{CHHC}\left(\mathrm{CH}_{3}\right)\right), 4.84(\mathrm{~d}$, $\left.{ }^{2} \mathrm{~J}(\mathrm{H}, \mathrm{H})=13.5 \mathrm{~Hz}, 1 \mathrm{H} ; \mathrm{CHHC}\left(\mathrm{CH}_{3}\right)\right), 4.52\left(\mathrm{~d},{ }^{2} \mathrm{~J}(\mathrm{H}, \mathrm{H})=15.0 \mathrm{~Hz}, 1 \mathrm{H} ; \mathrm{py}-\mathrm{CH}\right)$, $3.93\left(\mathrm{~d},{ }^{2} \mathrm{~J}(\mathrm{H}, \mathrm{H})=13.5 \mathrm{~Hz}, 1 \mathrm{H} ; \mathrm{CHHC}\left(\mathrm{CH}_{3}\right)\right), 3.81\left(\mathrm{~d},{ }^{2} \mathrm{~J}(\mathrm{H}, \mathrm{H})=13.5 \mathrm{~Hz}, 1 \mathrm{H}\right.$; $\left.\mathrm{CHHC}\left(\mathrm{CH}_{3}\right)\right), 1.21\left(\mathrm{~s}, 9 \mathrm{H} ; \mathrm{C}\left(\mathrm{CH}_{3}\right)_{3}\right), 1.07\left(\mathrm{~s}, 9 \mathrm{H} ; \mathrm{C}\left(\mathrm{CH}_{3}\right)_{3}\right),-7.52 \mathrm{ppm}(\mathrm{d}$, $\left.{ }^{2} \mathrm{~J}(\mathrm{H}, \mathrm{P})=31.5 \mathrm{~Hz}, 1 \mathrm{H} ; \mathrm{RuH}\right) ;{ }^{31} \mathrm{P}\left\{{ }^{1} \mathrm{H}\right\} \mathrm{NMR}\left(202 \mathrm{MHz}, \mathrm{CD}_{2} \mathrm{Cl}_{2}\right): \delta=44.2 \mathrm{ppm}$; ${ }^{13} \mathrm{C}\left\{{ }^{1} \mathrm{H}\right\}$ NMR (126 MHz, $\left.\mathrm{CD}_{2} \mathrm{Cl}_{2}\right): \delta=211.0\left(\mathrm{~d},{ }^{2} \mathrm{~J}(\mathrm{C}, \mathrm{P})=16 \mathrm{~Hz} ; \mathrm{CO}\right), 190.3(\mathrm{br}$ s; C-2 imid), 185.2 (d, ${ }^{2} J(C, P)=82 \mathrm{~Hz}$; C-2 imid), 157.3 (C-2 py), 157.0 (C-2 py), 138.7 (C-4 py), 136.5 (br d, ${ }^{1} \mathrm{~J}(\mathrm{C}, \mathrm{P})=40 \mathrm{~Hz} ; 3 \mathrm{C}_{\mathrm{q}}$ arom, $\mathrm{PPh}_{3}$ ), 133.5 (d, ${ }^{3} \mathrm{~J}(\mathrm{C}, \mathrm{P})=11 \mathrm{~Hz} ; 6 \mathrm{CH}$ arom, $\left.\mathrm{PPh}_{3}\right), 130.0\left(3 \mathrm{CH}\right.$ arom, $\left.\mathrm{PPh}_{3}\right), 128.5\left(\mathrm{~d},{ }^{4} \mathrm{~J}(\mathrm{C}, \mathrm{P})\right.$ $=9 \mathrm{~Hz} ; 6 \mathrm{CH}$ arom, $\mathrm{PPh}_{3}$ ), 124.8 (C-3 py), 124.2 (C-3 py), 124.1 ( $\mathrm{CH}$ imid), 123.2 ( $\mathrm{CH}$ imid), 121.7 ( $\mathrm{CH}$ imid), 121.2 ( $\mathrm{CH}$ imid), $63.1\left(2 \mathrm{CH}_{2} \mathrm{C}\left(\mathrm{CH}_{3}\right)_{3}\right), 61.7$ (2 $\left.\mathrm{CH}_{2} \mathrm{C}\left(\mathrm{CH}_{3}\right)_{3}\right), 58.5$ (py- $\left.\mathrm{CH}_{2}\right), 56.0\left(\right.$ py- $\left.\mathrm{CH}_{2}\right), 34.1\left(\mathrm{C}\left(\mathrm{CH}_{3}\right)_{3}\right), 34.0\left(\mathrm{C}\left(\mathrm{CH}_{3}\right)_{3}\right)$, $29.0\left(3 \mathrm{CH}_{3}\right)$, 28.4 ppm (3 $\left.\mathrm{CH}_{3}\right)$; IR $\left(\mathrm{CH}_{2} \mathrm{Cl}_{2}\right): v=1919 \mathrm{~cm}^{-1}$ (CO); MS (ESI, DMSO/MeOH): $m / z(\%): 772(100)\left[(M-B r)^{+}\right]$. Fragmentation of ion $m / z=772$ : $510(100)\left[\left(M-B r-P P h_{3}\right)^{+}\right]$; elemental analysis calcd (\%) for $\mathrm{C}_{42} \mathrm{H}_{49} \mathrm{BrN}_{5} \mathrm{OPRu}$ : C 59.22, H 5.80, N 8.22; found: C 59.24, H 5.92, N 8.17. 
Complex $3 \mathbf{d}(\mathbf{C l})$ : A mixture of $\mathbf{2 d}(\mathbf{C l})(0.092 \mathrm{~g}, 0.13 \mathrm{mmol})$ and $\mathrm{RuHCl}(\mathrm{CO})\left(\mathrm{PPh}_{3}\right)_{3}(0.120 \mathrm{~g}, 0.13 \mathrm{mmol})$ in $\mathrm{CH}_{2} \mathrm{Cl}_{2}(8 \mathrm{~mL})$ was stirred for $6 \mathrm{~h}$. The resulting solution was filtered, brought to dryness and extracted with $\mathrm{MeOH}$ $(2 \times 5 \mathrm{~mL})$. Solvent was evaporated and the obtained solid was recrystallized from $\mathrm{MeOH} /$ toluene. Yellow solid (0.056 g, 51\%). Complex $3 \mathrm{~d}(\mathbf{C l})$, while stable under inert atmosphere in the solid state, decomposes in solution $\left(\mathrm{CH}_{2} \mathrm{Cl}_{2}\right.$, $\mathrm{MeOH}, \mathrm{MeCN}, \mathrm{THF})$. Hence, spectroscopically pure samples could not be obtained. Signals of the complex in the ${ }^{1} \mathrm{H}$ and ${ }^{13} \mathrm{C}\left\{{ }^{1} \mathrm{H}\right\}$ NMR spectra were assigned with the help of ${ }^{1} \mathrm{H},{ }^{13} \mathrm{C}-\mathrm{HMQC}$ and ${ }^{1} \mathrm{H},{ }^{13} \mathrm{C}-\mathrm{HMBC}$ experiments. ${ }^{1} \mathrm{H}$ $\operatorname{NMR}\left(500 \mathrm{MHz}, \mathrm{CD}_{2} \mathrm{Cl}_{2}\right.$ ): $\delta=8.11$ (s, $1 \mathrm{H} ; \mathrm{H}$ imid), 7.76 (s, $1 \mathrm{H} ; \mathrm{H}$ imid), 7.67 (d, $\left.{ }^{3} \mathrm{~J}(\mathrm{H}, \mathrm{H})=6.5 \mathrm{~Hz}, 1 \mathrm{H} ; \mathrm{H}-3 \mathrm{py}\right), 7.36(\mathrm{~m}, 2 \mathrm{H} ; \mathrm{H}-3 \mathrm{py}+\mathrm{H}-4 \mathrm{py}), 7.27$ (m, 4H; $3 \mathrm{H}$ arom, $\mathrm{PPh}_{3}+\mathrm{H}$ arom), $7.18\left(\mathrm{~m}, 13 \mathrm{H} ; 12 \mathrm{H}\right.$ arom, $\mathrm{PPh}_{3}+\mathrm{H}$ arom), 7.00 (s, $1 \mathrm{H}$; $\mathrm{H}$ imid), 6.86 (s, 1H; $\mathrm{H}$ arom), 6.75 (s, 1H; H arom), 6.62 (s, 1H; H imid), 6.29 (s, 2H; $2 \mathrm{H}$ arom), $6.14\left(\mathrm{~d},{ }^{2} J(\mathrm{H}, \mathrm{H})=14.0 \mathrm{~Hz}, 1 \mathrm{H}\right.$; py-CH $), 5.96\left(\mathrm{~d},{ }^{2} J(\mathrm{H}, \mathrm{H})=\right.$ $14.0 \mathrm{~Hz}, 1 \mathrm{H}$; py-CHH), $5.94\left(\mathrm{~d},{ }^{2} \mathrm{~J}(\mathrm{H}, \mathrm{H})=15.5 \mathrm{~Hz}, 1 \mathrm{H}\right.$; py-CHH), 4.51 (d, ${ }^{2} J(\mathrm{H}, \mathrm{H})=15.5 \mathrm{~Hz}, 1 \mathrm{H}$; py-CHH), 2.36 (br s, 6H; 2 Ar- $\left.\mathrm{CH}_{3}\right), 2.11$ (s, $6 \mathrm{H} ; 2$ Ar$\left.\mathrm{CH}_{3}\right),-7.56 \mathrm{ppm}\left(\mathrm{d},{ }^{2} \mathrm{~J}(\mathrm{H}, \mathrm{P})=27.5 \mathrm{~Hz}, 1 \mathrm{H} ; \mathrm{RuH}\right) ;{ }^{31} \mathrm{P}\left\{{ }^{1} \mathrm{H}\right\} \mathrm{NMR}(202 \mathrm{MHz}$, $\left.\mathrm{CD}_{2} \mathrm{Cl}_{2}\right): \delta=43.4 \mathrm{ppm} ;{ }^{13} \mathrm{C}\left\{{ }^{1} \mathrm{H}\right\} \operatorname{NMR}\left(126 \mathrm{MHz}, \mathrm{CD}_{2} \mathrm{Cl}_{2}\right): \delta=208.9\left(\mathrm{~d},{ }^{2} J(\mathrm{C}, \mathrm{P})\right.$ $=15 \mathrm{~Hz} ; \mathrm{CO}), 191.3\left(\mathrm{~d},{ }^{2} J(\mathrm{C}, \mathrm{P})=7 \mathrm{~Hz}\right.$; C-2 imid), $182.3\left(\mathrm{~d},{ }^{2} J(\mathrm{C}, \mathrm{P})=81 \mathrm{~Hz}\right.$; C2 imid), 158.0 (C-2 py), 157.4 (C-2 py), 140.6 ( $\mathrm{C}_{\mathrm{q}}$ arom), 140.2 ( $\mathrm{C}_{\mathrm{q}}$ arom), 138.7 (C-4 py), 138.4 (br s, CH arom), 137.9 (C-3 py), 136.9 (2 $\mathrm{C}_{\mathrm{q}}$ arom), 136.6 (2 $\mathrm{C}_{\mathrm{q}}$ arom), 133.2 (d, ${ }^{3} \mathrm{~J}(\mathrm{C}, \mathrm{P})=10 \mathrm{~Hz} ; 6 \mathrm{CH}$ arom, $\left.\mathrm{PPh}_{3}\right), 130.8$ (CH arom), 129.8 (3 $\mathrm{CH}$ arom, $\left.\mathrm{PPh}_{3}\right), 128.8(\mathrm{CH}$ arom $), 128.6\left(\mathrm{~d},{ }^{4} \mathrm{~J}(\mathrm{C}, \mathrm{P})=9 \mathrm{~Hz} ; 6 \mathrm{CH}\right.$ arom, $\left.\mathrm{PPh}_{3}\right)$, 125.6 (CH imid), 125.2 ( $\mathrm{CH}$ imid), 125.0 (CH imid), 124.5 (CH arom), 124.4 (C-3 py), 122.5 (2 CH arom), 121.9 ( $\mathrm{CH}$ imid), 59.3 (py- $\left.\mathrm{CH}_{2}\right), 56.0\left(\mathrm{py}-\mathrm{CH}_{2}\right), 21.4$ (2 Ar- $\mathrm{CH}_{3}$ ), 21.4 ppm (br s; $\left.2 \mathrm{Ar}-\mathrm{CH}_{3}\right)$; IR $\left(\mathrm{CH}_{2} \mathrm{Cl}_{2}\right): v=1934 \mathrm{~cm}^{-1}$ (CO); MS (ESI, DMSO/MeOH): $m / z(\%): 840(100)\left[(M-C l)^{+}\right]$. Fragmentation of ion $m / z=840$ : $578(100)\left[\left(\mathrm{M}-\mathrm{Cl}-\mathrm{PPh}_{3}\right)^{+}\right]$; HRMS (FAB): $\mathrm{m} / \mathrm{z}: 840.2350\left[(\mathrm{M}-\mathrm{Cl})^{+}\right]$, exact mass calculated for $\mathrm{C}_{48} \mathrm{H}_{45} \mathrm{~N}_{5} \mathrm{OP}^{102} \mathrm{Ru}: 840.2405$.

Complex 4d: A mixture of complex 2d(Cl) (0.363 g, $0.49 \mathrm{mmol})$ and $\mathrm{RuHCl}(\mathrm{CO})\left(\mathrm{PPh}_{3}\right)_{3}(0.471 \mathrm{~g}, 0.49 \mathrm{mmol})$ in $\mathrm{THF}(15 \mathrm{~mL})$ was heated at $60{ }^{\circ} \mathrm{C}$ 
for $24 \mathrm{~h}$. The resulting solution was filtered off, and the solid was extracted with MeCN $(3 \times 5 \mathrm{~mL})$. The solution was brought to dryness, and the solid was washed with cold THF $(2 \times 5 \mathrm{~mL})$ yielding complex $\mathbf{4 d}$ as a yellow solid $(0.034$ $\mathrm{g}, 11 \%)$. On the other hand, the THF solution was evaporated, and the solid was extracted with $\mathrm{MeOH}(2 \times 5 \mathrm{~mL})$. Solvent was removed under vacuum, and the obtained solid was recrystallized from $\mathrm{MeOH} /$ toluene. Complex $\mathbf{3} \mathbf{d}(\mathbf{C l})$ was obtained as a brown solid $(0.138 \mathrm{~g}, 33 \%)$. Low solubility in common organic solvents of $\mathbf{4} \mathbf{d}$ has not permitted full spectroscopic characterization. ${ }^{1} \mathrm{H}$ NMR $\left(500 \mathrm{MHz}, \mathrm{CD}_{2} \mathrm{Cl}_{2}, 278 \mathrm{~K}\right.$ ): $\delta=7.85\left(\mathrm{t},{ }^{3} \mathrm{~J}(\mathrm{H}, \mathrm{H})=7.7 \mathrm{~Hz}, 1 \mathrm{H} ; \mathrm{H}-4 \mathrm{py}\right), 7.62$ (d, ${ }^{2} J(H, H)=15.5 \mathrm{~Hz}, 1 \mathrm{H}$; py-CHH), $7.70(\mathrm{~s}, 2 \mathrm{H} ; 2 \mathrm{H}$ arom $), 7.50\left(\mathrm{~d},{ }^{3} \mathrm{~J}(\mathrm{H}, \mathrm{H})=7.6\right.$ $\mathrm{Hz}, 2 \mathrm{H} ; 2 \mathrm{H}-3$ py), 7.19 (s, 1H; H imid), 7.14 (s, 1H; H imid), 7.08 (m, 3H; $3 \mathrm{H}$ arom), $6.95\left(\mathrm{~m}, 3 \mathrm{H} ; \mathrm{H}\right.$ arom $+2 \mathrm{H}$ imid), $5.31\left(\mathrm{~d},{ }^{2} \mathrm{~J}(\mathrm{H}, \mathrm{H})=14.1 \mathrm{~Hz}, 1 \mathrm{H}\right.$; py$\mathrm{CHH}), 5.13\left(\mathrm{~d},{ }^{2} \mathrm{~J}(\mathrm{H}, \mathrm{H})=14.1 \mathrm{~Hz}, 1 \mathrm{H}\right.$; py-CHH), $4.89\left(\mathrm{~d},{ }^{2} \mathrm{~J}(\mathrm{H}, \mathrm{H})=14.7 \mathrm{~Hz}, 1 \mathrm{H}\right.$; py-CHH), 2.30 (s, 6H; $2 \mathrm{CH}_{3}$ ), 2.27 (s, $6 \mathrm{H} ; 2 \mathrm{CH}_{3}$ ), -16.01 (s, 1H; RuH); IR (Nujol): $v=1948,1934,1905 \mathrm{~cm}^{-1}$ (RuH, CO); MS (ESI, $\left.\mathrm{CH}_{2} \mathrm{Cl}_{2} / \mathrm{MeOH}\right): \mathrm{m} / \mathrm{z}$ (\%): $612(100)\left[(M-H)^{+}\right]$. Fragmentation of ion $m / z=612: 584$ (100) $\left[(\mathrm{M}-\mathrm{H}-\mathrm{CO})^{+}\right]$; elemental analysis calcd (\%) for $\mathrm{C}_{30} \mathrm{H}_{30} \mathrm{ClN}_{5} \mathrm{ORu}$ : C $58.77, \mathrm{H}$ 4.93, N 11.42; found: C 58.60, H 5.00, N 11.17.

Complex 4e: A mixture of $2 \mathrm{e}(\mathrm{Cl})(0.200 \mathrm{~g}, 0.26 \mathrm{mmol})$ and $\mathrm{RuHCl}(\mathrm{CO})\left(\mathrm{PPh}_{3}\right)_{3}$ $(0.250 \mathrm{~g}, 0.26 \mathrm{mmol})$ in $\mathrm{CH}_{2} \mathrm{Cl}_{2}(10 \mathrm{~mL})$ was stirred for $24 \mathrm{~h}$. The resulting mixture was filtered, and solvent was removed under reduced pressure. The solid was washed with toluene $(2 \times 5 \mathrm{~mL})$ and $\mathrm{Et}_{2} \mathrm{O}(4 \mathrm{~mL})$, and extracted with $\mathrm{MeOH}(2 \times 5 \mathrm{~mL})$. Recrystallization from $\mathrm{MeOH} /$ toluene yields complex $4 \mathrm{e}$ as a yellow solid $(0.065 \mathrm{~g}, 39 \%)$. A meaningful ${ }^{13} \mathrm{C}\left\{{ }^{1} \mathrm{H}\right\}$ NMR spectrum for $4 \mathrm{e}$ in a non-coordinating solvent could not be obtained due to low solubility of the product and significant line broadening. ${ }^{1} \mathrm{H} \mathrm{NMR}\left(500 \mathrm{MHz}, \mathrm{CD}_{2} \mathrm{Cl}_{2}, 238 \mathrm{~K}\right): \delta=$ $7.84\left(\mathrm{t},{ }^{3} \mathrm{~J}(\mathrm{H}, \mathrm{H})=7.6 \mathrm{~Hz}, 1 \mathrm{H} ; \mathrm{H}-4 \mathrm{py}\right), 7.49(\mathrm{~m}, 3 \mathrm{H} ; 2 \mathrm{H}-3 \mathrm{py}+\mathrm{py}-\mathrm{CH}), 7.20$ (s, $2 \mathrm{H} ; 2 \mathrm{H}$ imid), 6.93 (s, $1 \mathrm{H} ; \mathrm{H}$ arom), 6.88 (s, $1 \mathrm{H} ; \mathrm{H}$ arom), 6.85 (s, $2 \mathrm{H} ; 2 \mathrm{H}$ arom), 6.69 (s, 1H; H imid), 6.68 (s, 1H; H imid), 5.33 (m, 1H; py-CHH), 5.10 (d, ${ }^{2} J(H, H)=14.0 \mathrm{~Hz}, 1 \mathrm{H} ;$ py-CHH), $4.83\left(\mathrm{~d},{ }^{2} \mathrm{~J}(\mathrm{H}, \mathrm{H})=14.5 \mathrm{~Hz}, 1 \mathrm{H} ;\right.$ py-CHH), 2.31 (s, 3H; $\left.\mathrm{Ar}-\mathrm{CH}_{3}\right), 2.28$ (s, 3H; $\left.\mathrm{Ar}-\mathrm{CH}_{3}\right), 2.11\left(\mathrm{~s}, 3 \mathrm{H} ; \mathrm{Ar}-\mathrm{CH}_{3}\right), 2.03$ (s, 3H; $\left.\mathrm{Ar}-\mathrm{CH}_{3}\right)$, 1.87 (s, 3H; $\left.\mathrm{Ar}-\mathrm{CH}_{3}\right), 1.81$ (s, 3H; $\mathrm{Ar}-\mathrm{CH}_{3}$ ), -16.24 ppm (s, 1H; RuH); IR (Nujol): 
$v=1932(\mathrm{RuH}), 1878 \mathrm{~cm}^{-1}$ (CO); MS (ESI, $\left.\mathrm{CH}_{2} \mathrm{Cl}_{2} / \mathrm{MeOH}\right): \mathrm{m} / \mathrm{z}(\%): 608$ (100) $\left[(\mathrm{M}+\mathrm{H}-\mathrm{Cl})^{+}\right]$. Fragmentation of ion $\mathrm{m} / \mathrm{z}=608: 578$ (100) $\left[(\mathrm{M}-\mathrm{Cl}-\mathrm{CO})^{+}\right]$; elemental analysis calcd (\%) for $\mathrm{C}_{32} \mathrm{H}_{34} \mathrm{CIN}_{5} \mathrm{ORu}$ : C 59.94, $\mathrm{H} 5.34, \mathrm{~N}$ 10.92; found: C 59.89, H 5.30, N 10.79.

Complex $5 \mathrm{~d}(\mathrm{Cl})$ : A suspension of $\mathbf{4 d}(0.015 \mathrm{~g}, 0.02 \mathrm{mmol})$ in $\mathrm{MeCN}(3 \mathrm{~mL})$ was stirred for $24 \mathrm{~h}$, and volatiles were removed under reduced pressure. Complex $\mathbf{5 d}(\mathrm{Cl})$ was isolated as a yellow solid $(0.016 \mathrm{~g}, 94 \%)$. A meaningful ${ }^{13} \mathrm{C}\left\{{ }^{1} \mathrm{H}\right\}$ NMR spectrum for $\mathbf{5 d}(\mathbf{C l})$ could not be obtained due to low solubility of the product in $\mathrm{CD}_{2} \mathrm{Cl}_{2}$ and $\mathrm{CD}_{3} \mathrm{CN}$ and significant line broadening. ${ }^{1} \mathrm{H}$ NMR (500 $\left.\mathrm{MHz}, \mathrm{CD}_{3} \mathrm{CN}, 288 \mathrm{~K}\right): \delta=8.00\left(\mathrm{t},{ }^{3} \mathrm{~J}(\mathrm{H}, \mathrm{H})=7.3 \mathrm{~Hz}, 1 \mathrm{H} ; \mathrm{H}-4 \mathrm{py}\right), 7.70\left(\mathrm{~d},{ }^{3} \mathrm{~J}(\mathrm{H}, \mathrm{H})\right.$ $=7.1 \mathrm{~Hz}, 1 \mathrm{H} ; \mathrm{H}-3$ py), $7.68\left(\mathrm{~d},{ }^{3} \mathrm{~J}(\mathrm{H}, \mathrm{H})=6.6 \mathrm{~Hz}, 1 \mathrm{H} ; \mathrm{H}-3 \mathrm{py}\right), 7.16(\mathrm{~s}, 1 \mathrm{H} ; \mathrm{H}$ imid), 7.09 (br m, 8H; $6 \mathrm{H}$ arom $+2 \mathrm{H}$ imid), 7.06 (s, $1 \mathrm{H} ; \mathrm{H}$ imid), 5.53 (d, ${ }^{2} J(H, H)=15.6 \mathrm{~Hz}, 1 \mathrm{H}$; py-CHH), $5.47\left(\mathrm{~d},{ }^{2} \mathrm{~J}(\mathrm{H}, \mathrm{H})=14.5 \mathrm{~Hz}, 1 \mathrm{H}\right.$; py-CHH), 5.35 $\left(\mathrm{d},{ }^{2} \mathrm{~J}(\mathrm{H}, \mathrm{H})=16.2 \mathrm{~Hz}, 1 \mathrm{H}\right.$; py-CHH), $5.32\left(\mathrm{~d},{ }^{2} \mathrm{~J}(\mathrm{H}, \mathrm{H})=15.2 \mathrm{~Hz}, 1 \mathrm{H} ; \mathrm{py}-\mathrm{CH}\right)$, 2.30 (s, 6H; $2 \mathrm{CH}_{3}$ ), 2.27 (s, 6H; $2 \mathrm{CH}_{3}$ ), -13.87 (s, 1H; RuH); IR (Nujol): $v=$ $1908 \mathrm{~cm}^{-1}$ (CO); HRMS (FAB): $\mathrm{m} / \mathrm{z}: 577.1440\left[(\mathrm{M}-\mathrm{HCl}-\mathrm{MeCN})^{+}\right]$, exact mass calculated for $\mathrm{C}_{30} \mathrm{H}_{29} \mathrm{~N}_{5} \mathrm{O}^{102} \mathrm{Ru}: 577.1416$.

Complex $\mathbf{5 e}(\mathbf{C l})$ : This complex was prepared as described for $\mathbf{5 d}(\mathbf{C l})$. Yellow solid $(0.021 \mathrm{~g}, 99 \%) .{ }^{1} \mathrm{H}$ NMR $\left(400 \mathrm{MHz}, \mathrm{CD}_{3} \mathrm{CN}\right): \delta=7.97\left(\mathrm{t},{ }^{3} \mathrm{~J}(\mathrm{H}, \mathrm{H})=6.4 \mathrm{~Hz}\right.$, $1 \mathrm{H} ; \mathrm{H}-4 \mathrm{py}), 7.71\left(\mathrm{~d},{ }^{3} \mathrm{~J}(\mathrm{H}, \mathrm{H})=6.4 \mathrm{~Hz}, 2 \mathrm{H} ; 2 \mathrm{H}-3 \mathrm{py}\right), 7.54(\mathrm{~s}, 2 \mathrm{H} ; 2 \mathrm{H}$ imid), 6.93 (br s, 4H; $4 \mathrm{H}$ arom), 6.88 (s, 2H; $2 \mathrm{H}$ imid), 5.55 (br, 2H; 2 py-CHH), 5.33 (br, 2H; 2 py-CHH), 2.29 (br s, 6H; $2 \mathrm{Ar}_{-} \mathrm{CH}_{3}$ ), 1.88 (br s, $12 \mathrm{H} ; 4 \mathrm{Ar}-\mathrm{CH}_{3}$ ), -14.33 ppm (s, $1 \mathrm{H} ; \mathrm{RuH}) ;{ }^{13} \mathrm{C}\left\{{ }^{1} \mathrm{H}\right\} \mathrm{NMR}\left(400 \mathrm{MHz}, \mathrm{CD}_{3} \mathrm{CN}\right): \delta=206.6(\mathrm{CO})$, 190.1 (2 C-2 imid), 159.0 (br; 2 C-2 py), 140.4 (C-4 py), 139.6 (C arom), 137.2 (3 $\mathrm{C}_{\mathrm{q}}$ arom), 129.6 (2 C-3 py), 129.3 ( $\mathrm{C}_{\mathrm{q}}$ arom), 129.1 (2 CH imid), 125.9 ( $\mathrm{C}_{\mathrm{q}}$ arom), 125.4 (2 CH imid), 124.3 ( $\mathrm{C}_{\mathrm{q}}$ arom), 123.4 ( $\mathrm{C}_{\mathrm{q}}$ arom), 123.0 (br; $4 \mathrm{CH}$ arom), 56.4 (br; 2 py- $\mathrm{CH}_{2}$ ), 21.1 (2 $\left.\mathrm{Ar}-\mathrm{CH}_{3}\right), 18.5$ (2 $\left.\mathrm{Ar}-\mathrm{CH}_{3}\right), 18.0$ ppm (2 Ar$\mathrm{CH}_{3}$ ); IR (Nujol): $\quad v=1910 \mathrm{~cm}^{-1}$ (CO); HRMS (FAB): $\mathrm{m} / \mathrm{z}: 606.1846$ $\left[(\mathrm{M}-\mathrm{Cl}-\mathrm{MeCN})^{+}\right]$, exact mass calculated for $\mathrm{C}_{32} \mathrm{H}_{34} \mathrm{~N}_{5} \mathrm{O}^{102} \mathrm{Ru}: 606.1807$. 
Complex $\mathbf{5 d}\left(\mathrm{BF}_{4}\right)$ : A suspension of $\mathbf{4 d}(0.028 \mathrm{~g}, 0.05 \mathrm{mmol})$ in $\mathrm{MeCN}(2 \mathrm{~mL})$ was treated with $\mathrm{NaBF}_{4}(0.006 \mathrm{~g}, 0.05 \mathrm{mmol})$. The suspension was stirred for 4 $\mathrm{h}$, and the solvent was removed under reduced pressure. $\mathrm{CH}_{2} \mathrm{Cl}_{2}(5 \mathrm{~mL})$ was added to the resulting solid, and the suspension was filtered through a short pad of celite. Complex $\mathbf{5 d}$ was isolated as a yellow solid after solvent evaporation $(0.020 \mathrm{~g}, 61 \%) .{ }^{1} \mathrm{H}$ NMR $\left(400 \mathrm{MHz} ; \mathrm{CD}_{2} \mathrm{Cl}_{2}\right): \delta=7.89\left(\mathrm{t},{ }^{3} \mathrm{~J}(\mathrm{H}, \mathrm{H})=\right.$ $7.6 \mathrm{~Hz}, 1 \mathrm{H} ; \mathrm{H}-4$ py), $7.68\left(\mathrm{~d},{ }^{3} \mathrm{~J}(\mathrm{H}, \mathrm{H})=7.5 \mathrm{~Hz}, 1 \mathrm{H} ; \mathrm{H}-3 \mathrm{py}\right), 7.60\left(\mathrm{~d},{ }^{3} \mathrm{~J}(\mathrm{H}, \mathrm{H})=\right.$ $7.6 \mathrm{~Hz}, 1 \mathrm{H} ; \mathrm{H}-3 \mathrm{py}$ ), 7.34 (s, 2H; $2 \mathrm{H}$ imid), 7.08 (s, 4H; $4 \mathrm{H}$ arom), 7.04 (s, $1 \mathrm{H}$; $\mathrm{H}$ arom), 7.02 (s, 2H; $2 \mathrm{H}$ imid), $6.97\left(\mathrm{~s}, 1 \mathrm{H} ; \mathrm{H}\right.$ arom), $5.53\left(\mathrm{~d},{ }^{2} \mathrm{~J}(\mathrm{H}, \mathrm{H})=15.0\right.$ $\mathrm{Hz}, 1 \mathrm{H}$; py-CHH), $5.49\left(\mathrm{~d},{ }^{2} \mathrm{~J}(\mathrm{H}, \mathrm{H})=14.4 \mathrm{~Hz}, 1 \mathrm{H} ;\right.$ py-CHH), $5.28\left(\mathrm{~d},{ }^{2} \mathrm{~J}(\mathrm{H}, \mathrm{H})=\right.$ $14.8 \mathrm{~Hz}, 1 \mathrm{H}$; py-CHH), $5.26\left(\mathrm{~d},{ }^{2} \mathrm{~J}(\mathrm{H}, \mathrm{H})=14.0 \mathrm{~Hz}, 1 \mathrm{H} ; \mathrm{py}-\mathrm{CH}\right), 2.31(\mathrm{~s}, 6 \mathrm{H} ; 2$ $\mathrm{CH}_{3}$ ), 2.29 (s, 6H; $2 \mathrm{CH}_{3}$ ), 1.81 (s, 3H; MeCN), -13.89 (s, $\left.1 \mathrm{H} ; \mathrm{RuH}\right) ;{ }^{13} \mathrm{C}\left\{{ }^{1} \mathrm{H}\right\}$ NMR (126 MHz, $\mathrm{CD}_{2} \mathrm{Cl}_{2}, 273 \mathrm{~K}$ ): $\delta=207.1$ (CO), 189.1 (C-2 imid), 188.4 (C-2 imid), 157.7 (C-2 py), 157.1 (C-2 py), 140.8 ( $\mathrm{C}_{\mathrm{q}}$ arom), 140.4 ( $\mathrm{C}_{\mathrm{q}}$ arom), 139.4 (C-4 py), 138.8 (2 $\mathrm{C}_{\mathrm{q}}$ arom), 138.7 (2 $\mathrm{C}_{\mathrm{q}}$ arom), $130.3(\mathrm{CH}$ arom), $129.9(\mathrm{CH}$ arom), 125.4 (2 CH arom), 125.1 (C-3 py), $125.0(2 \mathrm{CH}$ arom $+\mathrm{MeCN}), 124.4$ (C-3 py), 123.3 ( $\mathrm{CH}$ imid), 122.7 ( $\mathrm{CH}$ imid), 122.0 ( $\mathrm{CH}$ imid), 121.6 ( $\mathrm{CH}$ imid), 57.5 (py- $\mathrm{CH}_{2}$ ), 54.9 (py- $\left.\mathrm{CH}_{2}\right), 21.2\left(4 \mathrm{CH}_{3}\right), 3.5$ (br, $\mathrm{MeCN}$ ); IR (Nujol): $v=1967$ (RuH), $1909 \mathrm{~cm}^{-1}$ (CO); MS (ESI, $\left.\mathrm{CH}_{2} \mathrm{Cl}_{2} / \mathrm{MeCN}\right): \mathrm{m} / \mathrm{z}$ (\%): 578 (100) [(M-BF $\left.{ }_{4}-\mathrm{MeCM}^{+}\right]$; HRMS (FAB): $\mathrm{m} / \mathrm{z}: 578.1490$ [(M-BF $\left.\left.{ }_{4}-\mathrm{MeCM}\right)^{+}\right]$, exact mass calculated for $\mathrm{C}_{30} \mathrm{H}_{30} \mathrm{~N}_{5} \mathrm{O}^{102} \mathrm{Ru}: 578.1494$.

Complex $\mathbf{5 e}\left(\mathbf{B F}_{4}\right)$ : This complex was prepared as described for $\mathbf{5 d}\left(\mathbf{B F}_{4}\right)$. Yellow solid (0.022 g, 97\%). ' $\mathrm{H}$ NMR $\left(500 \mathrm{MHz}, \mathrm{CD}_{2} \mathrm{Cl}_{2}, 313 \mathrm{~K}\right): \delta=7.91$ (t, ${ }^{3} \mathrm{~J}(\mathrm{H}, \mathrm{H})=7.5 \mathrm{~Hz}, 1 \mathrm{H}, \mathrm{H}-4$ py), $7.69\left(\mathrm{~d},{ }^{3} \mathrm{~J}(\mathrm{H}, \mathrm{H})=7.5 \mathrm{~Hz}, 2 \mathrm{H} ; 2 \mathrm{H}-3\right.$ py), 7.44 (d, ${ }^{3} \mathrm{~J}(\mathrm{H}, \mathrm{H})=1.3 \mathrm{~Hz}, 2 \mathrm{H} ; 2 \mathrm{H}$ imid), 6.94 (s, 2H; $2 \mathrm{H}$ arom), 6.89 (s, 2H; $2 \mathrm{H}$ arom), $6.78\left(\mathrm{~d},{ }^{3} \mathrm{~J}(\mathrm{H}, \mathrm{H})=1.5 \mathrm{~Hz}, 2 \mathrm{H} ; 2 \mathrm{H}\right.$ imid), 5.49 (br s, 2H; 2 py-CHH), 5.37 (d, ${ }^{2} J(\mathrm{H}, \mathrm{H})=15.0 \mathrm{~Hz}, 2 \mathrm{H} ; 2$ py-CHH), $2.33\left(\mathrm{~s}, 6 \mathrm{H} ; 2 \mathrm{Ar}_{-} \mathrm{CH}_{3}\right), 2.02$ (s, 3H; MeCN), 1.94 (br s, 6H; $2 \mathrm{Ar}-\mathrm{CH}_{3}$ ), 1.91 (br s, 6H; $2 \mathrm{Ar}-\mathrm{CH}_{3}$ ), -14.5 ppm (s, 1H; RuH); ${ }^{13} \mathrm{C}\left\{{ }^{1} \mathrm{H}\right\}$ NMR $\left(\mathrm{CD}_{2} \mathrm{Cl}_{2}, 126 \mathrm{MHz}, 313 \mathrm{~K}\right): \delta=205.6$ (CO), 190.1 (2 C-2 imid), 158.0 (br; 2 C-2 py), 139.5 (C-4 py), 139.2 (2 $\mathrm{C}_{\mathrm{q}}$ arom), 136.8 (m; $6 \mathrm{C}_{\mathrm{q}}$ arom), 129.3 (2 C-3 py), 128.6 (2 CH imid), 124.8 (2 CH imid), 122.4 (m; $4 \mathrm{CH}$ arom + $\mathrm{MeCN}), 56.4$ (br; 2 py- $\mathrm{CH}_{2}$ ), $21.2\left(2 \mathrm{Ar}-\mathrm{CH}_{3}\right), 18.5\left(2 \mathrm{Ar}-\mathrm{CH}_{3}\right), 18.1\left(2 \mathrm{Ar}-\mathrm{CH}_{3}\right)$, 
3.9 ppm (MeCN); IR (Nujol): $v=1932 \mathrm{~cm}^{-1}$ (CO); MS (ESI, $\left.\mathrm{CH}_{2} \mathrm{Cl}_{2} / \mathrm{MeCN}\right): \mathrm{m} / z$

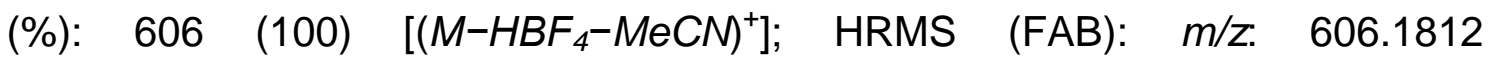
$\left[\left(M-\mathrm{HBF}_{4}-\mathrm{MeCM}\right)^{+}\right]$, exact mass calculated for $\mathrm{C}_{32} \mathrm{H}_{34} \mathrm{~N}_{5} \mathrm{O}^{102} \mathrm{Ru}: 606.1807$.

\section{Complexes $\mathrm{RuH}_{2}(\mathrm{CNC})(\mathrm{CO})(9)$}

Complex 9a: In a J.-Young valved NMR tube, a solution of $3 a(C l) ~(0.013 \mathrm{~g}$, $0.02 \mathrm{mmol})$ in $\left[\mathrm{D}_{8}\right]$ THF $(0.7 \mathrm{~mL})$ was treated with $\mathrm{tBuOK}(0.002 \mathrm{~g}, 0.02 \mathrm{mmol})$ forming a dark-red solution. The solution was pressurized with 3 bar of $\mathrm{H}_{2}$ and heated to $55{ }^{\circ} \mathrm{C}$ for $1.5 \mathrm{~h}$. Complex $9 \mathrm{a}$ was only stable under a $\mathrm{H}_{2}$ atmosphere. ${ }^{1} \mathrm{H}$ NMR (500 MHz, [D 8 THF): $\delta=7.64\left(\mathrm{t},{ }^{3} \mathrm{~J}(\mathrm{H}, \mathrm{H})=7.5 \mathrm{~Hz}, 1 \mathrm{H} ; \mathrm{H}-4 \mathrm{py}\right), 7.13-$ $7.40\left(\mathrm{~m}, 19 \mathrm{H} ; 2 \mathrm{H}-3\right.$ py $+2 \mathrm{H}$ imid + free $\left.\mathrm{PPh}_{3}\right), 7.01\left(\mathrm{~d},{ }^{3} \mathrm{~J}(\mathrm{H}, \mathrm{H})=1.5 \mathrm{~Hz}, 2 \mathrm{H} ; 2\right.$ $\mathrm{H}$ imid), $5.61\left(\mathrm{~d},{ }^{2} \mathrm{~J}(\mathrm{H}, \mathrm{H})=13.0 \mathrm{~Hz}, 2 \mathrm{H} ; 2 \mathrm{py}-\mathrm{CH}\right), 5.54\left(\mathrm{~h},{ }^{3} \mathrm{~J}(\mathrm{H}, \mathrm{H})=6.5 \mathrm{~Hz}\right.$, $\left.2 \mathrm{H} ; 2 \mathrm{CH}\left(\mathrm{CH}_{3}\right)_{2}\right), 5.29\left(\mathrm{~d},{ }^{2} J(\mathrm{H}, \mathrm{H})=13.0 \mathrm{~Hz}, 2 \mathrm{H} ; 2\right.$ py-CH $), 1.49\left(\mathrm{~d},{ }^{3} J(\mathrm{H}, \mathrm{H})=\right.$ $\left.6.5 \mathrm{~Hz}, 6 \mathrm{H} ; 2 \mathrm{CH}_{3}\right), 1.33\left(\mathrm{~d},{ }^{3} \mathrm{~J}(\mathrm{H}, \mathrm{H})=6.5 \mathrm{~Hz}, 6 \mathrm{H} ; 2 \mathrm{CH}_{3}\right),-5.70$ ppm (s, 2H; 2 $\mathrm{RuH}) ;{ }^{13} \mathrm{C}\left\{{ }^{1} \mathrm{H}\right\}$ NMR (101 MHz, [D $]$ THF): $\delta=214.3$ (CO), 201.3 (2 C-2 imid), 159.1 (2 C-2 py), 135.8 (C-4 py), 121.7 (2 C-3 py), 119.4 (2 CH imid), 114.8 (2 $\mathrm{CH}$ imid), 57.4 (2 py- $\left.\mathrm{CH}_{2}\right), 51.7\left(2 \mathrm{CH}\left(\mathrm{CH}_{3}\right)_{2}\right), 24.0\left(2 \mathrm{CH}_{3}\right), 22.1 \mathrm{ppm}\left(2 \mathrm{CH}_{3}\right)$.

Complex 9d: In a J.-Young valved NMR tube, a solution of $\mathbf{5 e}\left(\mathbf{B F}_{4}\right)(0.010 \mathrm{~g}$, $0.01 \mathrm{mmol})$ in $\left[\mathrm{D}_{8}\right] \mathrm{THF}(0.7 \mathrm{~mL})$ was treated with $t$ BuOK $(0.002 \mathrm{~g}, 0.02 \mathrm{mmol})$. The solution was pressurized with 3 bar of $\mathrm{H}_{2}$ and heated to $50{ }^{\circ} \mathrm{C}$ for $1 \mathrm{~h} .{ }^{1} \mathrm{H}$ NMR data for the resulting product is in agreement with previously reported data for this product. ${ }^{[12]}{ }^{1} \mathrm{H}$ NMR $\left(500 \mathrm{MHz},\left[\mathrm{D}_{8}\right] \mathrm{THF}\right): \delta=7.64\left(\mathrm{t},{ }^{3} \mathrm{~J}(\mathrm{H}, \mathrm{H})=7.7\right.$ $\mathrm{Hz}, 1 \mathrm{H} ; \mathrm{H}-4$ py), 7.38 (d, ${ }^{3} J(\mathrm{H}, \mathrm{H})=7.7 \mathrm{~Hz}, 2 \mathrm{H} ; 2 \mathrm{H}-3$ py), $7.23\left(\mathrm{~d},{ }^{3} J(\mathrm{H}, \mathrm{H})=1.7\right.$ $\mathrm{Hz}, 2 \mathrm{H} ; 2 \mathrm{H}$ imid), 6.73 (s, 2H; $2 \mathrm{H}$ arom), 6.73 (s, 2H; $2 \mathrm{H}$ arom), 6.61 (d, ${ }^{3} J(H, H)=1.7 \mathrm{~Hz}, 2 \mathrm{H} ; 2 \mathrm{H}$ imid $), 5.59\left(\mathrm{~d},{ }^{2} J(\mathrm{H}, \mathrm{H})=12.5 \mathrm{~Hz}, 2 \mathrm{H} ; 2\right.$ py-CHH), 5.30 $\left(\mathrm{d},{ }^{2} \mathrm{~J}(\mathrm{H}, \mathrm{H})=12.5 \mathrm{~Hz}, 2 \mathrm{H} ; 2 \mathrm{py}-\mathrm{CH}\right), 2.21$ (s, 6H; $\left.2 \mathrm{CH}_{3}\right), 1.95\left(\mathrm{~s}, 6 \mathrm{H} ; 2 \mathrm{CH}_{3}\right)$, $1.93\left(\mathrm{~s}, 6 \mathrm{H} ; 2 \mathrm{CH}_{3}\right),-5.96 \mathrm{ppm}(\mathrm{s}, 2 \mathrm{H} ; 2 \mathrm{RuH})$.

\section{Procedure for the preparation of complexes 10}


In a NMR tube, a suspension of $5 \mathbf{e}\left(\mathrm{BF}_{4}\right)(0.020 \mathrm{~g}, 0.03 \mathrm{mmol})$ and the corresponding imine $\left(0.03-0.04 \mathrm{mmol}, 1.0-1.6\right.$ equiv) in $\left[\mathrm{D}_{8}\right] \mathrm{THF}(0.7 \mathrm{~mL})$ was treated with tBuOK $(0.003 \mathrm{~g}, 0.03 \mathrm{mmol})$. The resulting solution was immediately analyzed by NMR. Attempted isolation of complexes $\mathbf{1 0}$ led to product decomposition.

Complex 10a: ${ }^{1} \mathrm{H}$ NMR $\left(500 \mathrm{MHz},\left[\mathrm{D}_{8}\right] \mathrm{THF}\right): \delta=7.45\left(\mathrm{~d},{ }^{3} \mathrm{~J}(\mathrm{H}, \mathrm{H})=1.5 \mathrm{~Hz}, 1 \mathrm{H}\right.$; $\mathrm{H}$ imid), $7.40\left(\mathrm{dd},{ }^{3} \mathrm{~J}(\mathrm{H}, \mathrm{H})=7.5 \mathrm{~Hz},{ }^{3} \mathrm{~J}(\mathrm{H}, \mathrm{H})=7.5 \mathrm{~Hz}, 1 \mathrm{H} ; \mathrm{H}-4\right.$ py), 7.39 (d, ${ }^{3} \mathrm{~J}(\mathrm{H}, \mathrm{H})=1.5 \mathrm{~Hz}, 1 \mathrm{H} ; \mathrm{H}$ imid), $7.33\left(\mathrm{~d},{ }^{3} \mathrm{~J}(\mathrm{H}, \mathrm{H})=7.5 \mathrm{~Hz}, 1 \mathrm{H} ; \mathrm{H}-3\right.$ py), 6.84 (s, $1 \mathrm{H} ; \mathrm{H}$ arom, mesityl), $6.79(\mathrm{~m}, 8 \mathrm{H} ; \mathrm{H}-3$ py $+2 \mathrm{H}$ arom, mesityl $+5 \mathrm{H}$ arom, $\mathrm{NPh}), 6.74\left(\mathrm{~d},{ }^{3} \mathrm{~J}(\mathrm{H}, \mathrm{H})=1.5 \mathrm{~Hz}, 1 \mathrm{H} ; \mathrm{H}\right.$ imid $), 6.66\left(\mathrm{~d},{ }^{3} \mathrm{~J}(\mathrm{H}, \mathrm{H})=1.5 \mathrm{~Hz}, 1 \mathrm{H} ; \mathrm{H}\right.$ imid), 6.35 (s, 1H; H arom, mesityl), $6.18\left(\mathrm{dd},{ }^{3} \mathrm{~J}(\mathrm{H}, \mathrm{H})=7.5 \mathrm{~Hz},{ }^{3} \mathrm{~J}(\mathrm{H}, \mathrm{H})=7.5\right.$ $\mathrm{Hz}, 2 \mathrm{H} ; 2 \mathrm{H}$ arom, PhCN), $6.10\left(\mathrm{~d},{ }^{3} \mathrm{~J}(\mathrm{H}, \mathrm{H})=8.0 \mathrm{~Hz}, 2 \mathrm{H} ; 2 \mathrm{H}\right.$ arom, PhCN), 5.87 $\left(\mathrm{d},{ }^{3} \mathrm{~J}(\mathrm{H}, \mathrm{H})=5.5 \mathrm{~Hz}, 1 \mathrm{H}\right.$; py-CH), $5.66\left(\mathrm{dd},{ }^{3} \mathrm{~J}(\mathrm{H}, \mathrm{H})=6.5 \mathrm{~Hz},{ }^{3} \mathrm{~J}(\mathrm{H}, \mathrm{H})=6.5 \mathrm{~Hz}\right.$, $1 \mathrm{H} ; \mathrm{H}$ arom, PhCN), $5.49\left(\mathrm{~d},{ }^{2} \mathrm{~J}(\mathrm{H}, \mathrm{H})=13.5 \mathrm{~Hz}, 1 \mathrm{H} ;\right.$ py-CHH), $5.35\left(\mathrm{~d},{ }^{2} \mathrm{~J}(\mathrm{H}, \mathrm{H})=\right.$ $13.5 \mathrm{~Hz}, 1 \mathrm{H}$; py-CHH), $4.46\left(\mathrm{~d},{ }^{3} \mathrm{~J}(\mathrm{H}, \mathrm{H})=5.0 \mathrm{~Hz}, 1 \mathrm{H}\right.$; CHNRu), 2.26 (s, 3H; Ar$\mathrm{CH}_{3}$ ), 2.25 (s, 3H; $\mathrm{Ar}-\mathrm{CH}_{3}$ ), 2.02 (s, 3H; $\mathrm{Ar}-\mathrm{CH}_{3}$ ), 1.88 (s, 3H; $\mathrm{Ar}-\mathrm{CH}_{3}$ ), 1.74 (s, 3H; $\mathrm{Ar}-\mathrm{CH}_{3}$ ), 1.42 (s, 3H; $\left.\mathrm{Ar}-\mathrm{CH}_{3}\right),-13.72$ ppm (s, 1H; RuH); ${ }^{13} \mathrm{C}\left\{{ }^{1} \mathrm{H}\right\}$ NMR (126 $\left.\mathrm{MHz},\left[\mathrm{D}_{8}\right] \mathrm{THF}\right): \delta=210.7$ (CO), 197.4 (2 C-2 imid), $162.2\left(\mathrm{C}_{\mathrm{q}}\right.$ arom), $160.2\left(\mathrm{C}_{\mathrm{q}}\right.$ arom), 157.3 ( $\mathrm{C}_{\mathrm{q}}$ arom $), 149.6\left(\mathrm{C}_{\mathrm{q}}\right.$ arom $), 138.4$ ( $\mathrm{C}_{\mathrm{q}}$ arom), $138.4\left(\mathrm{C}_{\mathrm{q}}\right.$ arom $)$, $138.1\left(\mathrm{C}_{\mathrm{q}}\right.$ arom $), 138.0\left(\mathrm{C}_{\mathrm{q}}\right.$ arom $), 137.8\left(\mathrm{C}_{\mathrm{q}}\right.$ arom $), 137.4\left(\mathrm{C}_{\mathrm{q}}\right.$ arom $), 136.8\left(\mathrm{C}_{\mathrm{q}}\right.$ arom), $136.6\left(\mathrm{CH}\right.$ arom), 136.0 ( $\mathrm{C}_{\mathrm{q}}$ arom $), 131.2(\mathrm{CH}$ arom), 129.4 (2 $\mathrm{CH}$ arom), 128.7 (2 CH arom), 128.0 (2 CH arom), 127.9 (2 CH arom), 127.5 (2 CH arom), $126.0(\mathrm{CH}$ arom), $124.2(\mathrm{CH}$ arom), $122.9(\mathrm{CH}$ imid), $121.9(\mathrm{CH}$ arom), 121.5 ( $\mathrm{CH}$ arom), 120.8 ( $\mathrm{CH}$ arom), 120.6 ( $\mathrm{CH}$ imid), 118.1 (2 CH arom), $107.1(\mathrm{CH}$ arom), 71.9 (py-CH), 63.7 (CHNRu), 57.8 (py- $\left.\mathrm{CH}_{2}\right), 21.3\left(\mathrm{Ar}^{-} \mathrm{CH}_{3}\right), 21.2$ (Ar$\left.\mathrm{CH}_{3}\right), 18.7\left(2 \mathrm{Ar}-\mathrm{CH}_{3}\right), 18.4\left(\mathrm{Ar}-\mathrm{CH}_{3}\right), 18.3 \mathrm{ppm}\left(\mathrm{Ar}-\mathrm{CH}_{3}\right)$.

Complex 10b: ${ }^{1} \mathrm{H}$ NMR $\left(500 \mathrm{MHz},\left[\mathrm{D}_{8}\right] \mathrm{THF}\right): \delta=7.43\left(\mathrm{dd},{ }^{3} \mathrm{~J}(\mathrm{H}, \mathrm{H})=7.5 \mathrm{~Hz}\right.$, ${ }^{3} J(H, H)=7.5 \mathrm{~Hz}, 1 \mathrm{H} ; \mathrm{H}-4$ py), $7.42\left(\mathrm{~d},{ }^{3} \mathrm{~J}(\mathrm{H}, \mathrm{H})=2.0 \mathrm{~Hz}, 1 \mathrm{H} ; \mathrm{H}\right.$ imid), $7.38(\mathrm{~d}$, ${ }^{3} \mathrm{~J}(\mathrm{H}, \mathrm{H})=1.5 \mathrm{~Hz}, 1 \mathrm{H} ; \mathrm{H}$ imid), $7.33\left(\mathrm{~d},{ }^{3} \mathrm{~J}(\mathrm{H}, \mathrm{H})=7.5 \mathrm{~Hz}, 1 \mathrm{H} ; \mathrm{H}-3 \mathrm{py}\right), 6.85$ (s, $1 \mathrm{H} ; \mathrm{H}$ arom, mesityl), $6.82\left(\mathrm{~d},{ }^{3} \mathrm{~J}(\mathrm{H}, \mathrm{H})=7.5 \mathrm{~Hz}, 1 \mathrm{H} ; \mathrm{H}-3\right.$ py), $6.78(\mathrm{~s}, 1 \mathrm{H} ; \mathrm{H}$ arom, mesityl), $6.77\left(\mathrm{~s}, 1 \mathrm{H} ; \mathrm{H}\right.$ arom, mesityl), $6.72\left(\mathrm{~d},{ }^{3} \mathrm{~J}(\mathrm{H}, \mathrm{H})=2.0 \mathrm{~Hz}, 1 \mathrm{H} ; \mathrm{H}\right.$ 
imid), $6.69\left(\mathrm{~d},{ }^{3} \mathrm{~J}(\mathrm{H}, \mathrm{H})=8.0 \mathrm{~Hz}, 2 \mathrm{H} ; 2 \mathrm{H}\right.$ arom, N(MeO-Ph)), $6.65\left(\mathrm{~d},{ }^{3} \mathrm{~J}(\mathrm{H}, \mathrm{H})=\right.$ $1.5 \mathrm{~Hz}, 1 \mathrm{H} ; \mathrm{H}$ imid), 6.38 (s, $1 \mathrm{H} ; \mathrm{H}$ arom), $6.35\left(\mathrm{~d},{ }^{3} \mathrm{~J}(\mathrm{H}, \mathrm{H})=8.5 \mathrm{~Hz}, 2 \mathrm{H} ; 2 \mathrm{H}\right.$ arom, $\mathrm{N}(\mathrm{MeO}-\mathrm{Ph})), 6.02\left(\mathrm{~d},{ }^{3} \mathrm{~J}(\mathrm{H}, \mathrm{H})=9.5 \mathrm{~Hz}, 2 \mathrm{H} ; 2 \mathrm{H}\right.$ arom, (MeO-Ph)CN), $5.91\left(\mathrm{~d},{ }^{3} \mathrm{~J}(\mathrm{H}, \mathrm{H})=9.5 \mathrm{~Hz}, 2 \mathrm{H} ; 2 \mathrm{H}\right.$ arom, (MeO-Ph)CN), $5.80\left(\mathrm{~d},{ }^{3} \mathrm{~J}(\mathrm{H}, \mathrm{H})=5.5\right.$ $\mathrm{Hz}, 1 \mathrm{H}$; py-CH), $5.48\left(\mathrm{~d},{ }^{2} J(\mathrm{H}, \mathrm{H})=13.5 \mathrm{~Hz}, 1 \mathrm{H}\right.$; py-CHH), $5.34\left(\mathrm{~d},{ }^{2} J(\mathrm{H}, \mathrm{H})=\right.$ $13.5 \mathrm{~Hz}, 1 \mathrm{H}$; py-CHH), $4.36\left(\mathrm{~d},{ }^{3} \mathrm{~J}(\mathrm{H}, \mathrm{H})=5.0 \mathrm{~Hz}, 1 \mathrm{H} ; \mathrm{CHNRu}\right), 3.55$ (s, 3H; Ar$\mathrm{OCH}_{3}$ ), 3.51 (s, 3H; Ar- $\mathrm{OCH}_{3}$ ), 2.29 (s, 3H; $\mathrm{Ar}-\mathrm{CH}_{3}$ ), 2.24 (s, 3H; $\mathrm{Ar}-\mathrm{CH}_{3}$ ), 2.02 (s, 3H; $\left.\mathrm{Ar}-\mathrm{CH}_{3}\right), 1.89$ (s, 3H; $\left.\mathrm{Ar}-\mathrm{CH}_{3}\right), 1.73$ (s, 3H; $\left.\mathrm{Ar}-\mathrm{CH}_{3}\right), 1.43$ (s, 3H; $\mathrm{Ar}-\mathrm{CH}_{3}$ ),

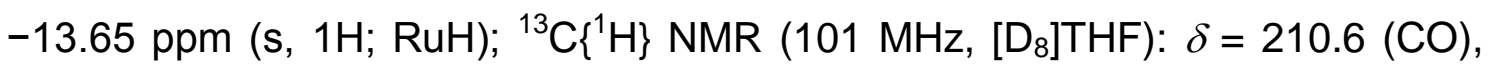
197.3 (C-2 imid), 197.2 (C-2 imid), 160.2 ( $C_{q}$ arom), 158.5 ( $C_{q}$ arom), 157.7 ( $C_{q}$ arom), 157.0 ( $\mathrm{C}_{\mathrm{q}}$ arom), $145.9\left(\mathrm{C}_{\mathrm{q}}\right.$ arom $), 141.5$ ( $\mathrm{C}_{\mathrm{q}}$ arom), $138.4\left(\mathrm{C}_{\mathrm{q}}\right.$ arom $)$, $138.2\left(\mathrm{C}_{\mathrm{q}}\right.$ arom $), 138.0\left(\mathrm{C}_{\mathrm{q}}\right.$ arom $), 137.9\left(\mathrm{C}_{\mathrm{q}}\right.$ arom $), 137.8\left(\mathrm{C}_{\mathrm{q}}\right.$ arom $), 137.3\left(\mathrm{C}_{\mathrm{q}}\right.$ arom), 136.7 ( $\mathrm{C}_{\mathrm{q}}$ arom), $136.4\left(\mathrm{CH}\right.$ arom), $135.9\left(\mathrm{C}_{\mathrm{q}}\right.$ arom $), 130.9(\mathrm{CH}$ arom), 130.6 ( $\mathrm{CH}$ arom), 129.2 ( $\mathrm{CH}$ arom), 128.6 (2 $\mathrm{CH}$ arom), 128.5 ( $\mathrm{CH}$ arom), 124.1 (CH imid), $122.6(\mathrm{CH}$ arom), $121.7(\mathrm{CH}$ arom $), 121.3(\mathrm{CH}$ arom $), 120.6(\mathrm{CH}$ imid), 120.3 ( $\mathrm{CH}$ arom), 115.8 ( $\mathrm{CH}$ arom), 115.0 ( $\mathrm{CH}$ arom), 114.7 ( $\mathrm{CH}$ arom), $114.5(\mathrm{CH}$ arom), $114.3(\mathrm{CH}$ arom), $113.2(\mathrm{CH}$ arom), 72.1 (py-CH), 63.7 (CHNRu), $57.7\left(\right.$ py- $\left.\mathrm{CH}_{2}\right), 56.5\left(\mathrm{Ar}-\mathrm{OCH}_{3}\right), 54.8\left(\mathrm{Ar}-\mathrm{OCH}_{3}\right), 21.2\left(\mathrm{Ar}-\mathrm{CH}_{3}\right), 21.0$ $\left(\mathrm{Ar}-\mathrm{CH}_{3}\right), 18.6\left(\mathrm{Ar}-\mathrm{CH}_{3}\right), 18.5\left(\mathrm{Ar}-\mathrm{CH}_{3}\right), 18.2\left(\mathrm{Ar}-\mathrm{CH}_{3}\right), 18.1 \mathrm{ppm}\left(\mathrm{Ar}-\mathrm{CH}_{3}\right)$.

Complex 10c: ${ }^{1} \mathrm{H}$ NMR $\left(500 \mathrm{MHz},\left[\mathrm{D}_{8}\right] \mathrm{THF}\right): \delta=7.43\left(\mathrm{dd},{ }^{3} \mathrm{~J}(\mathrm{H}, \mathrm{H})=7.5 \mathrm{~Hz}\right.$, ${ }^{3} \mathrm{~J}(\mathrm{H}, \mathrm{H})=7.5 \mathrm{~Hz}, 1 \mathrm{H} ; \mathrm{H}-4$ py), $7.42\left(\mathrm{~d},{ }^{3} \mathrm{~J}(\mathrm{H}, \mathrm{H})=2.0 \mathrm{~Hz}, 1 \mathrm{H} ; \mathrm{H}\right.$ imid), 7.39 (d, ${ }^{3} \mathrm{~J}(\mathrm{H}, \mathrm{H})=2.0 \mathrm{~Hz}, 1 \mathrm{H} ; \mathrm{H}$ imid), $7.35\left(\mathrm{~d},{ }^{3} \mathrm{~J}(\mathrm{H}, \mathrm{H})=7.5 \mathrm{~Hz}, 1 \mathrm{H} ; \mathrm{H}-3 \mathrm{py}\right), 6.86$ (s, $1 \mathrm{H} ; \mathrm{H}$ arom, mesityl), $6.81\left(\mathrm{~d},{ }^{3} \mathrm{~J}(\mathrm{H}, \mathrm{H})=7.5 \mathrm{~Hz}, 1 \mathrm{H} ; \mathrm{H}-3 \mathrm{py}\right), 6.78(\mathrm{~s}, 1 \mathrm{H} ; \mathrm{H}$ arom, mesityl), $6.78\left(\mathrm{~s}, 1 \mathrm{H} ; \mathrm{H}\right.$ arom, mesityl), $6.74\left(\mathrm{~d},{ }^{3} \mathrm{~J}(\mathrm{H}, \mathrm{H})=2.0 \mathrm{~Hz}, 1 \mathrm{H} ; \mathrm{H}\right.$ imid), 6.66 (m, 3H; $\mathrm{H}$ imid + $2 \mathrm{H}$ arom), $6.36(\mathrm{~m}, 3 \mathrm{H} ; 3 \mathrm{H}$ arom), $5.99(\mathrm{~m}, 2 \mathrm{H} ; 2$ $\mathrm{H}$ arom, (F-Ph)CN), $5.92\left(\mathrm{~m}, 2 \mathrm{H} ; 2 \mathrm{H}\right.$ arom, (F-Ph)CN), $5.78\left(\mathrm{~d},{ }^{3} \mathrm{~J}(\mathrm{H}, \mathrm{H})=5.0\right.$ $\mathrm{Hz}, 1 \mathrm{H}$; py-CH), $5.48\left(\mathrm{~d},{ }^{2} J(\mathrm{H}, \mathrm{H})=13.5 \mathrm{~Hz}, 1 \mathrm{H}\right.$; py-CHH), $5.35\left(\mathrm{~d},{ }^{2} J(\mathrm{H}, \mathrm{H})=\right.$ $13.5 \mathrm{~Hz}, 1 \mathrm{H}$; py-CHH), $4.28\left(\mathrm{~d},{ }^{3} \mathrm{~J}(\mathrm{H}, \mathrm{H})=5.5 \mathrm{~Hz}, 1 \mathrm{H} ; \mathrm{CHNRu}\right), 3.55\left(\mathrm{Ar}-\mathrm{OCH}_{3}\right)$, 2.27 (s, 3H; $\mathrm{Ar}-\mathrm{CH}_{3}$ ), 2.24 (s, 3H; $\mathrm{Ar}-\mathrm{CH}_{3}$ ), 2.02 (s, 3H; $\mathrm{Ar}-\mathrm{CH}_{3}$ ), 1.88 (s, 3H; Ar$\mathrm{CH}_{3}$ ), 1.73 (s, 3H; $\mathrm{Ar}-\mathrm{CH}_{3}$ ), 1.43 (s, 3H; $\mathrm{Ar}-\mathrm{CH}_{3}$ ), -13.78 ppm (s, $1 \mathrm{H} ; \mathrm{RuH}$ ); ${ }^{19} \mathrm{~F}\left\{{ }^{1} \mathrm{H}\right\}$ NMR (376 MHz, [D 8$\left.] \mathrm{THF}\right): \delta=-143.2 \mathrm{ppm} ;{ }^{13} \mathrm{C}\left\{{ }^{1} \mathrm{H}\right\} \mathrm{NMR}(101 \mathrm{MHz}$, $\left[\mathrm{D}_{8}\right] \mathrm{THF}$ ): $\delta=210.5$ (CO), 196.9 (2 C-2 imid), 160.1 ( $\mathrm{C}_{\mathrm{q}}$ arom), 158.8 ( $\mathrm{C}_{\mathrm{q}}$ arom), 
$158.6\left(\mathrm{C}_{\mathrm{q}}\right.$ arom), 157.1 ( $\mathrm{C}_{\mathrm{q}}$ arom), $151.1\left(\mathrm{~d}, \mathrm{~J}(\mathrm{C}, \mathrm{F})=222 \mathrm{~Hz}\right.$; $\mathrm{C}_{\mathrm{q}}$ arom), 140.8 ( $\mathrm{C}_{\mathrm{q}}$ arom), 138.4 ( $\mathrm{C}_{\mathrm{q}}$ arom), $138.0\left(\mathrm{C}_{\mathrm{q}}\right.$ arom $), 137.9$ ( $\mathrm{C}_{\mathrm{q}}$ arom), 137.8 ( $\mathrm{C}_{\mathrm{q}}$ arom), $137.6\left(\mathrm{CH}\right.$ arom), 136.8 ( $\mathrm{C}_{\mathrm{q}}$ arom), $136.6\left(\mathrm{CH}\right.$ arom), 135.9 ( $\mathrm{C}_{\mathrm{q}}$ arom), 130.8 (CH arom), 129.3 ( $\mathrm{CH}$ arom), 128.6 (2 $\mathrm{CH}$ arom), $128.6(\mathrm{CH}$ arom), $124.2(\mathrm{CH}$ arom), $122.7(\mathrm{CH}$ arom), $121.8(\mathrm{CH}$ arom $), 121.4(\mathrm{CH}$ arom $), 120.7(\mathrm{CH}$ arom), $120.4(\mathrm{CH}$ arom), 116.7 (2 CH arom), 113.2 (2 CH arom), $113.0(\mathrm{CH}$ arom), 112.8 ( $\mathrm{CH}$ arom), 72.0 (py-CH), $63.7(\mathrm{CHNRu}), 57.7\left(\mathrm{py}-\mathrm{CH}_{2}\right), 54.8\left(\mathrm{Ar}-\mathrm{OCH}_{3}\right)$, $21.0\left(2 \mathrm{Ar}-\mathrm{CH}_{3}\right), 18.6\left(\mathrm{Ar}-\mathrm{CH}_{3}\right), 18.5\left(\mathrm{Ar}-\mathrm{CH}_{3}\right), 18.3\left(\mathrm{Ar}-\mathrm{CH}_{3}\right), 18.0 \mathrm{ppm}(\mathrm{Ar}-$ $\left.\mathrm{CH}_{3}\right)$.

Complex 10d: ${ }^{1} \mathrm{H}$ NMR (500 MHz, [D 8 ] THF): $\delta=7.48\left(\mathrm{dd},{ }^{3} \mathrm{~J}(\mathrm{H}, \mathrm{H})=7.5 \mathrm{~Hz}\right.$, ${ }^{3} \mathrm{~J}(\mathrm{H}, \mathrm{H})=7.5 \mathrm{~Hz}, 1 \mathrm{H} ; \mathrm{H}-4$ py), $7.43\left(\mathrm{~d},{ }^{3} \mathrm{~J}(\mathrm{H}, \mathrm{H})=2.0 \mathrm{~Hz}, 1 \mathrm{H} ; \mathrm{H}\right.$ imid), 7.40 (d, ${ }^{3} \mathrm{~J}(\mathrm{H}, \mathrm{H})=2.0 \mathrm{~Hz}, 1 \mathrm{H} ; \mathrm{H}$ imid), $7.38\left(\mathrm{~d},{ }^{3} \mathrm{~J}(\mathrm{H}, \mathrm{H})=7.5 \mathrm{~Hz}, 1 \mathrm{H} ; \mathrm{H}-3 \mathrm{py}\right), 6.87$ (s, $1 \mathrm{H} ; \mathrm{H}$ arom, mesityl), $6.84\left(\mathrm{~d},{ }^{3} \mathrm{~J}(\mathrm{H}, \mathrm{H})=7.5 \mathrm{~Hz}, 1 \mathrm{H} ; \mathrm{H}-3 \mathrm{py}\right), 6.77(\mathrm{~m}, 7 \mathrm{H} ; 6 \mathrm{H}$ arom $+\mathrm{H}$ imid), $6.68\left(\mathrm{~d},{ }^{3} \mathrm{~J}(\mathrm{H}, \mathrm{H})=2.0 \mathrm{~Hz}, 1 \mathrm{H} ; \mathrm{H}\right.$ imid), $6.51\left(\mathrm{~d},{ }^{3} \mathrm{~J}(\mathrm{H}, \mathrm{H})=8.5\right.$ $\mathrm{Hz}, 2 \mathrm{H} ; 2 \mathrm{H}$ arom), $6.49\left(\mathrm{~d},{ }^{3} \mathrm{~J}(\mathrm{H}, \mathrm{H})=8.5 \mathrm{~Hz}, 2 \mathrm{H} ; 2 \mathrm{H}\right.$ arom), $6.39(\mathrm{~s}, 1 \mathrm{H} ; \mathrm{H}$ arom, mesityl), $5.95(\mathrm{~m}, 4 \mathrm{H} ; 4 \mathrm{H}$ arom, $(\mathrm{F}-\mathrm{Ph}) \mathrm{CN}), 5.82\left(\mathrm{~d},{ }^{3} \mathrm{~J}(\mathrm{H}, \mathrm{H})=5.1 \mathrm{~Hz}\right.$, $1 \mathrm{H}$; py-CH), $5.48\left(\mathrm{~d},{ }^{2} J(\mathrm{H}, \mathrm{H})=13.5 \mathrm{~Hz}, 1 \mathrm{H}\right.$; py-CHH), $5.36\left(\mathrm{~d},{ }^{2} \mathrm{~J}(\mathrm{H}, \mathrm{H})=13.5\right.$ $\mathrm{Hz}, 1 \mathrm{H} ; \mathrm{py}-\mathrm{CH}), 4.35\left(\mathrm{~d},{ }^{3} \mathrm{~J}(\mathrm{H}, \mathrm{H})=5.1 \mathrm{~Hz}, 1 \mathrm{H} ; \mathrm{CHNRu}\right), 2.28$ (s, 3H; $\left.\mathrm{Ar}-\mathrm{CH}_{3}\right)$, 2.25 (s, 3H; $\mathrm{Ar}-\mathrm{CH}_{3}$ ), 2.02 (s, 3H; Ar-CH $), 1.89$ (s, 3H; Ar- $\mathrm{CH}_{3}$ ), 1.73 (s, 3H; Ar$\left.\mathrm{CH}_{3}\right), 1.41$ (s, 3H; $\left.\mathrm{Ar}-\mathrm{CH}_{3}\right),-13.80 \mathrm{ppm}(\mathrm{s}, 1 \mathrm{H} ; \mathrm{RuH}) ;{ }^{19} \mathrm{~F}\left\{{ }^{1} \mathrm{H}\right\} \mathrm{NMR}(376 \mathrm{MHz}$, $\left.\left[\mathrm{D}_{8}\right] \mathrm{THF}\right): \delta=-142.8,-118.8 \mathrm{ppm} ;{ }^{13} \mathrm{C}\left\{{ }^{1} \mathrm{H}\right\} \mathrm{NMR}\left(101 \mathrm{MHz},\left[\mathrm{D}_{8}\right] \mathrm{THF}\right): \delta=210.4$ (CO), 196.9 (C-2 imid), 196.7 (C-2 imid), 161.7 (d, J(C,F) = $243 \mathrm{~Hz}$; $\mathrm{C}_{\mathrm{q}}$ arom), $159.7\left(\mathrm{C}_{\mathrm{q}}\right.$ arom), $158.6\left(\mathrm{C}_{\mathrm{q}}\right.$ arom $), 157.3$ ( $\mathrm{C}_{\mathrm{q}}$ arom), $151.2(\mathrm{~d}, \mathrm{~J}(\mathrm{C}, \mathrm{F})=223 \mathrm{~Hz}$; $\mathrm{C}_{\mathrm{q}}$ arom), $145.6\left(\mathrm{C}_{\mathrm{q}}\right.$ arom), 144.9 ( $\mathrm{C}_{\mathrm{q}}$ arom), 138.3 ( $\mathrm{C}_{\mathrm{q}}$ arom), 138.0 ( $\mathrm{C}_{\mathrm{q}}$ arom), $137.9(\mathrm{CH}$ arom $), 137.6\left(\mathrm{C}_{\mathrm{q}}\right.$ arom $), 137.4\left(\mathrm{C}_{\mathrm{q}}\right.$ arom $), 136.8\left(\mathrm{C}_{\mathrm{q}}\right.$ arom $), 136.7\left(\mathrm{C}_{\mathrm{q}}\right.$ arom), $135.8\left(\mathrm{C}_{\mathrm{q}}\right.$ arom), $130.8(\mathrm{CH}$ arom), $128.7(\mathrm{~m} ; 3 \mathrm{CH}$ arom), $128.6(\mathrm{~d}$, $J(\mathrm{C}, \mathrm{F})=15 \mathrm{~Hz}, \mathrm{CH}$ arom), $124.1(\mathrm{CH}$ arom $), 122.7(\mathrm{CH}$ arom), $122.1(\mathrm{CH}$ arom), $121.5(\mathrm{CH}$ arom), 120.7 ( $\mathrm{CH}$ arom), $120.4(\mathrm{CH}$ arom), $116.6(\mathrm{CH}$ arom), $115.5(\mathrm{~d}, J(\mathrm{C}, \mathrm{F})=23 \mathrm{~Hz}, \mathrm{CH}$ arom), $115.4(\mathrm{CH}$ arom), $114.3(\mathrm{~d}, J(\mathrm{C}, \mathrm{F})=21 \mathrm{~Hz}$, $\mathrm{CH}$ arom), 113.0 (d, J(C,F) = 20 Hz, CH arom), 71.5 (py-CH), 63.4 (CHNRu), 57.5 (py- $\left.\mathrm{CH}_{2}\right), 21.0\left(2 \mathrm{Ar}-\mathrm{CH}_{3}\right), 18.5\left(2 \mathrm{Ar}-\mathrm{CH}_{3}\right), 18.1\left(\mathrm{Ar}-\mathrm{CH}_{3}\right), 17.9$ ppm (Ar$\left.\mathrm{CH}_{3}\right)$. 


\section{Representative procedure for catalytic hydrogenation reactions of imines}

In a glovebox, a Fischer-Porter vessel was charged with a solution of complex $3 \mathbf{b}(\mathrm{Cl})(1.2 \mathrm{mg}, 1.4 \mu \mathrm{mol})$, tBuOK $(1.6 \mathrm{mg}, 14.0 \mu \mathrm{mol})$ and the corresponding imine $(1.4 \mathrm{mmol})$ in 2-methyltetrahydrofuran $(1.0 \mathrm{~mL})$. The reactor was purged three times with $\mathrm{H}_{2}$, and finally pressurized to 5 bar and heated to $70{ }^{\circ} \mathrm{C}$. After $6 \mathrm{~h}$, the reactor was slowly cooled down to room temperature and depressurized. The reaction solution was evaporated, and conversion was determined by ${ }^{1} \mathrm{H}$ NMR spectroscopy.

\section{Procedure for the hydrogenation of phenanthridine}

In a glovebox, a Parr-type reactor ( $40 \mathrm{~mL}$ ) was charged with a solution of complex $3 \mathbf{b}(\mathbf{C l}) \quad(4.2 \mathrm{mg}, 5.6 \mu \mathrm{mol})$, tBuOK $(6.3 \mathrm{mg}, 56.1 \mu \mathrm{mol})$ and phenanthridine $(0.251 \mathrm{~g}, 1.4 \mathrm{mmol})$ in 2-methyltetrahydrofuran $(1.5 \mathrm{~mL})$. The reactor was purged three times with $\mathrm{H}_{2}$, and finally pressurized to 10 bar and heated to $80{ }^{\circ} \mathrm{C}$. After $24 \mathrm{~h}$, the reactor was slowly cooled down to room temperature and depressurized. The reaction solution was evaporated, and conversion was determined by ${ }^{1} \mathrm{H}$ NMR spectroscopy.

\section{Procedure for the dehydrogenation of 5,6-dihydrophenanthridine}

A solution of complex $3 \mathbf{b}(\mathrm{Cl})(1.0 \mathrm{mg}, 1.3 \mu \mathrm{mol})$, tBuOK (1.5 mg, 13.0 $\mu \mathrm{mol})$ and 5,6-dihydrophenanthridine $(0.024 \mathrm{~g}, 0.13 \mathrm{mmol})$ in dioxane $(1.0 \mathrm{~mL})$ was refluxed for $24 \mathrm{~h}$. Conversion was determined by GC-MS and ${ }^{1} \mathrm{H}$ NMR spectroscopy.

\section{Acknowledgements}

Financial support (FEDER contribution) from the Spanish MINECO (CTQ2009-11867), Consolider-Ingenio 2010 (CSD2007-00006), and the Junta de Andalucía (2008/FQM-3830, 2009/FQM-4832) is gratefully acknowledged. M. H. J. thanks CONACYT for a fellowship (214238). The use of Computational 
facilities of the supercomputing Center of Galicia (CESGA) is also acknowledged. J.L.-S thanks the MICINN and the European Social Fund for a "Ramón y Cajal" contract. P. L. thanks the Spanish Ministry of Economy and Competitivity for a Juan de la Cierva contract.

[1] a) J. I. van der Vlugt, J. N. H. Reek, Angew. Chem. 2009, 121, 89909004; Angew. Chem. Int. Ed. 2009, 48, 8832-8846; b) J. I. van der Vlugt, Eur. J. Inorg. Chem. 2012, 363-375; c) S. Schneider, J. Meiners, B. Askevold, Eur. J. Inorg. Chem. 2012, 412-429; d) S. E. Clapham, A. Hadzovic, R. H. Morris, Coord. Chem. Rev. 2004, 248, 2201-2237; e) H. Grutzmacher, Angew. Chem. 2008, 120, 1838-1842; Angew. Chem. Int. Ed. 2008, 47, 1814-1818; f) T. Ikariya, M. Shibasaki, Top. Organomet. Chem. 2011, Vol. 37.

[2] a) C. Gunanathan, D. Milstein, Acc. Chem. Res. 2011, 44, 588-602; b) J. I. van der Vlugt, M. Lutz, E. A. Pidko, D. Vogt, A. L. Spek, Dalton Trans. 2009, 1016-1023; c) J. I. van der Vlugt, E. A. Pidko, R. C. Bauer, Y. Gloaguen, M. K. Rong, M. Lutz, Chem. Eur. J. 2011, 17, 3850-3854; d) Y-H. Chang, Y. Nakajima, H. Tanaka, K. Yoshizawa, F. Ozawa, J. Am. Chem. Soc. 2013, 135, 11791-11794.

[3] J. I. van der Vlugt, E. A. Pidko, D. Vogt, M. Lutz, A. L. Spek, Inorg. Chem. 2009, 48, 7513-7515.

[4] For leading examples of reactivity of metal complexes as FLP: a) A. M. Chapman, M. F. Haddow, D. F. Wass, J. Am. Chem. Soc. 2011, 133, 18463-18478; b) M. J. Sgro, D. W. Stephan, Angew. Chem. 2012, 124, 11505-11507; Angew. Chem. Int. Ed. 2011, 51, 11343-11345; c) M. J. Sgro, D. W. Stephan, Chem. Commun. 2013, 49, 2610-2612; d) X. Xu, G. Kehr, C. G. Daniliuc, G. Erker, J. Am. Chem. Soc. 2014, 136, 1243112443.

[5] a) M. Vogt, M. Gargir, M. A. Iron, Y. Diskin-Posner, Y. Ben-David, D. Milstein, Chem. Eur. J. 2012, 18, 9194-9197; b) C. A. Huff, J. W. Kampf, M. S. Sanford, Organometallics 2012, 31, 4643-4645; c) M. Montag, J. Zhang, D. Milstein, J. Am. Chem. Soc. 2012, 134, 10325-10328; d) C. A. 
Huff, J. W. Kampf, M. S. Sanford, Chem. Commun. 2013, 49, 7147-7149; e) C. A. Huff, M. S. Sanford, ACS Catal. 2013, 3, 2412-2416; f) G. A. Filonenko, M. P. Conley, C. Copéret, M. Lutz, E. J. M. Hensen, E. A. Pidko, ACS Catal. 2013, 3, 2522-2526; g) M. Vogt, A. Nerush, M. A. Iron, G. Leitus, Y. Diskin-Posner, L. J. W. Shimon, Y. Ben-David, D. Milstein, J. Am. Chem. Soc. 2013, 135, 17004-70018; h) M. Vogt, A. Nerush, Y. Diskin-Posner, Y. Ben-David, D. Milstein, Chem. Sci. 2014, 5, 20432051.

[6] a) C. Gunanathan, D. Milstein, Top. Organomet. Chem. 2011, 37, 55-84; b) J. Zhang, G. Leitus, Y. Ben-David, D. Milstein, Angew. Chem. 2006, 118, 1131-1133; Angew. Chem. Int. Ed. 2006, 45, 1113-1115; c) E. Balaraman, B. Gnanaprakasam, L. J. W. Shimon, D. Milstein, J. Am. Chem. Soc. 2010, 132, 16756-16758; d) E. Balaraman, Y. Ben-David, D. Milstein, Angew. Chem. 2011, 123, 11906-11909; Angew. Chem. Int. Ed. 2011, 50, 11702-11705; e) E. Balaraman, C. Gunanathan, J. Zhang, L. J. W. Shimon, D. Milstein, Nature Chem. 2011, 3, 609-614; f) E. M. Krall, T. W. Klein, R. J. Andersen, A. J. Nett, R. W. Glasgow, D. S. Reader, B. C. Dauphinais, S. P. Mc Ilrath, A. A. Fischer, M. J. Carney, D. J. Hudson, N. J. Robertson, Chem. Commun. 2014, 50, 4884-4887; g) D. Srimani, M. Feller, Y. Ben-David, D. Milstein, Chem. Commun. 2012, 48, 1185311855; h) C. A. Huff, M. S. Sanford, J. Am. Chem. Soc. 2011, 133, 18122-18125; i) G. A. Filonenko, R. van Putten, E. N. Schulpen, E. J. M. Hensen, E. A. Pidko, ChemCatChem 2014, 6, 1526-1530; j) refs. 5e-f.

[7] a) C. Gunanathan, D. Milstein, Science 2013, 341, 249-260; b) J. Zhang, M. Gandelman, L. J. W. Shimon, H. Rozenberg, D. Milstein, Organometallics 2004, 23, 4026-4033; c) J. Zhang, G. Leitus, Y. BenDavid, D. Milstein, J. Am. Chem. Soc. 2005, 127, 10840-10841; d) B. Gnanaprakasam, J. Zhang, D. Milstein, Angew. Chem. 2010, 122, 15101513; Angew. Chem. Int. Ed. 2010, 49, 1468-1471; e) J. Zhang, M. Gandelman, L. J. W. Shimon, D. Milstein, Dalton Trans. 2007, 107-113; f) E. Balaraman, E. Khaskin, G. Leitus, D. Milstein, Nature Chem. 2013, 5, 122-125; g) C. Gunanathan, Y. Ben-David, D. Milstein, Science 2007, 317, 790-792; h) M. Nielsen, A. Kammer, D. Cozzula, H. Junge, S. 
Gladiali, M. Beller, Angew. Chem. 2011, 123, 9767-9771; Angew. Chem. Int. Ed. 2011, 50, 9593-9597; i) B. Gnanaprakasam, E. Balaraman, Y. Ben-David, D. Milstein, Angew. Chem. 2011, 123, 12448-12452; Angew. Chem. Int. Ed. 2011, 50, 12240-12244; j) H. Zeng, Z. Guan, J. Am. Chem. Soc. 2011, 133, 1159-1161; k) D. Srimani, E. Balaraman, B. Gnanaprakasam, Y. Ben-David, D. Milstein, Adv. Synth. Catal. 2012, 354, 2403-2406, I) J. W. Rigoli, S. A. Moyer, S. D. Pearce, J. M. Schomaker, Org. Biomol. Chem. 2012, 10, 1746-1749; m) D. Srimani, Y. Ben-David, D. Milstein, Angew. Chem. 2013, 125, 14381-14384; Angew. Chem. Int. Ed. 2013, 52, 4012-4015.

[8] a) R. H. Crabtree, J. Organomet. Chem. 2005, 690, 5451-5457; b) W. A. Herrmann, Angew. Chem. 2002, 114, 1342-1363; Angew. Chem. Int. Ed. 2002, 41, 1290-1309; c) G. C. Vougioukalakis, R. H. Grubbs, Chem. Rev. 2010, 110, 1746-1787; d) A. T. Normand, K. J. Cavell, Eur. J. Inorg. Chem. 2008, 2781-2800; e) H. D. Velazquez, F. Verpoort, Chem. Soc. Rev. 2012, 41, 7032-7060; f) M.-T. Lee, C.-H. Hu, Organometallics 2004, 23, 976-983.

[9] Y. Sun, C. Koehler, R. Tan, V. T. Annibale, D. Song, Chem. Commun. 2011, 47, 8349-8351.

[10] a) E. Fogler, E. Balaraman, Y. Ben-David, G. Leitus, L. J. W. Shimon, D. Milstein, Organometallics 2011, 30, 3826-3833; b) E. Balaraman, E. Fogler, D. Milstein, Chem. Commun. 2012, 48, 1111-1113.

[11] C. del Pozo, M. Iglesias, F. Sánchez, Organometallics 2011, 30 , 2180-2188.

[12] G. A. Filonenko, E. Cosimi, L. Lefort, M. P. Conley, C. Copéret, M. Lutz, E. J. M. Hensen, E. A. Pidko, ACS Catal. 2014, 4, 2667-2671.

[13] a) Handbook of Homogeneous Hydrogenation, Vols. 1-3 (Eds.: J. G. de Vries, C. J. Elsevier), Wiley-VCH, Weinheim, 2007; b) C. Claver, E. Fernández in Modern Reduction Methods (Eds.: P. G. Andersson, I. J. Munslow), Wiley-VCH, Weinheim, 2008, Cap. 10; c) J-H. Xie, S-F. Zhu, Q-L. Zhou, Chem. Rev. 2011, 111, 1713-1760; d) for an overview of different mechanisms in the hydrogenation of imines: A. Fabrello, A. 
Bachelier, M. Urrutigoïty, P. Kalck, Coord. Chem. Rev. 2010, 254, 273287 , and references therein.

[14] a) C. Wang, B. Villa-Marcos, J. Xiao, Chem. Commun. 2011, 47, 97739785, and references therein; b) N. Fleury-Brégeot, V. de la Fuente, S. Castillón, C. Claver, ChemCatChem 2011, 2, 1346-1371, and references therein; c) P. Maire, T. Büttner, F. Breher, P. Le Floch, H. Grützmacher, Angew. Chem. 2005, 117, 6477-6481; Angew. Chem. Int. Ed. 2005, 44, 6318-6323; d) N. Arai, N. Utsumi, Y. Matsumoto, K. Murata, K. Tsutsumi, T. Ohkuma, Adv. Synth. Catal. 2012, 354, 2089-2095; e) M. Vaquero, A. Suárez, S. Vargas, G. Bottari, E. Álvarez, A. Pizzano, Chem. Eur. J. 2012, 18, 15586-15591; f) A. Comes-Vives, G. Ujaque, A. Lledós, Organometallics 2008, 27, 4854-4863; g) C. P. Casey, G. A. Bikzhanova, I. A. Guzei, J. Am. Chem. Soc. 2006, 128, 2286-2293, and references therein.

[15] M. Hernández-Juárez, M. Vaquero, E. Álvarez, V. Salazar, A. Suárez, Dalton Trans. 2013, 42, 351-354.

[16] a) I. J. B. Lin, H. M. J. Wang, Organometallics 1998, 17, 972-975; b) J. C. Garrison, W. J. Youngs, Chem. Rev. 2005, 105, 3978-4008; c) I. J. B. Lin, C. S. Vasam, Coord. Chem. Rev. 2007, 251, 642-670.

[17] a) A. A. D. Tulloch, A. A. Danopoulos, G. J. Tizzard, S. J. Coles, M. B. Hursthouse, R. S. Hay-Motherwell, W. B. Motherwell, Chem. Commun. 2001, 1270-1271; b) R. S. Simons, P. Custer, C. A. Tessier, W. J. Youngs, Organometallics 2003, 22, 1979-1982; c) A. A. Danopoulos, A. A. D. Tulloch, S. Winston, G. Eastham, M. B. Hursthouse, Dalton Trans. 2003, 1009-1015; d) D. J. Nielsen, K. J. Cavell, B. W. Skelton, A. H. White, Inorg. Chim. Acta 2006, 359, 1855-1869; e) K. Inamoto, J. Kuroda, E. Kwon, K. Hiroya, T. Doi, J. Organomet. Chem. 2009, 694, 389-396.

[18] Only mer coordination of CNC ligands has been reported: a) ref. 17; b) $D$. Pugh, A. A. Danopoulos, Coord. Chem. Rev. 2007, 251, 610-641, and references therein; c) D. Serra, P. Cao, J. Cabrera, R. Padilla, F. Rominger, M. Limbach, Organometallics 2011, 30, 1885-1895; d) J. 
Dinda, S. Liatard, J. Chauvin, D. Jouvenot, F. Loiseau, Dalton Trans. 2001, 40, 3683-3688.

[19] Generation of complex $4 \mathbf{e}$ has been previously reported, although it was not isolated and fully characterized (ref. 11). Also, the synthesis of the bromine analogue of $4 \mathbf{e}$ by reaction of the corresponding bis-imidazolium salt with $\mathrm{RuHCl}(\mathrm{CO})\left(\mathrm{PPh}_{3}\right)_{3}$ in the presence of a phosphazene base has been described (ref. 12).

[20] a) R. S. Rowland, R. Taylor, J. Phys. Chem. 1996, 100, 7384-7391; b) J. Reedijk, Chem. Soc. Rev. 2013, 42, 1776-1783.

[21] A X-ray diffraction study of $\mathbf{5 e}\left(\mathbf{B F}_{4}\right)$ has been reported (ref. 12).

[22] a) S. Gründemann, M. Albrecht, J. A. Loch, J. W. Faller, R. H. Crabtree, Organometallics 2001, 20, 5485-5488; b) J. R. Miecznikowski, S. Gründemann, M. Albrecht, C. Mégret, E. Clot, J. W. Faller, O. Eisenstein, R. H. Crabtree, Dalton Trans. 2003, 831-838.

[23] P. J. Heard, Chem. Soc. Rev. 2007, 36, 551-569.

[24] E. L. Eliel, S. H. Wilen, L. N. Mander, Stereochemistry of Organic Compounds, John Wiley \& Sons, New York, 1994, pp. 720-722.

[25] 2-Methyltetrahydrofuran is a green solvent: D. F. Aycock, Org. Process Res. Dev. 2007, 11, 156-159.

[26] a) R. H. Crabtree, Energy Environ. Sci. 2008, 1, 134-138; b) R. Yamaguchi, C. Ikeda, Y. Takahashi, K. Fujita, J. Am. Chem. Soc. 2009, 131, 8410-8412; c) D. Dean, B. Davis, P. G. Jessop, New J. Chem. 2011, 35, 417-422; d) S. Muthaiah, S. H. Hong, Adv. Synth. Catal. 2012, 354, 3045-3053; e) J. Wu, D. Talwar, S. Johnston, M. Yan, J. Xiao, Angew. Chem. 2013, 125, 7121-7125; Angew. Chem. Int. Ed. 2013, 52, 6983-6987; f) D. F. Brayton, C. M. Jensen, Chem. Commun. 2014, 50, 5987-5989; g) K. Fujita, Y. Tanaka, M. Kobayashi, R. Yamaguchi, J. Am. Chem. Soc. 2014, 136, 4829-4832; h) S. Chakraborty, W. W. Brennessel, W. D. Jones, J. Am. Chem. Soc. 2014, 136, 8564-8567.

[27] a) Q-A. Chen, K. Gao, Y. Duan, Z-S. Ye, L. Shi, Y. Yang, Y-G. Zhou, J. Am. Chem. Soc. 2012, 134, 2442-2448; b) L-Q. Lu, Y. Li, K. Junge, M. Beller, Angew. Chem. 2013, 125, 8540-8544; Angew. Chem. Int. Ed. 2013, 52, 8382-8386. 
[28] a) X. Yang, M. B. Hall, J. Am. Chem. Soc. 2010, 132, 120-130; b) J. Li, Y. Shiota, K. Yoshizawa J. Am. Chem. Soc. 2009, 131, 13584-13585.

[29] E. Khaskin, M. A. Iron, L. J. W. Shimon, J. Zhang, D. Milstein J. Am. Chem. Soc. 2010, 132, 8542-8543.

[30] For example, the iminic proton of $6 \mathrm{a}$ appears at $\delta_{\mathrm{H}}=8.50 \mathrm{ppm}$, while in the case of the corresponding amine the protons of the $\mathrm{CH}_{2} \mathrm{~N}$ fragment appear at $\delta_{\mathrm{H}}=4.35 \mathrm{ppm}$.

[31] Reversible ketimido and enamido complex formation in a Re-PNP system has recently been reported (ref. $5 \mathrm{~g}$ ).

[32] a) J. M. Mayer, Comments Inorg. Chem. 1988, 8, 125-135; b) D. Conner, K. N. Jayaprakash, M. B. Wells, S. Manzer, T. B. Gunnoe, P. D. Boyle, Inorg. Chem. 2003, 42, 4759-4772. The E-C bond theory may also be invoked to explain the observed stability trend: c) P. L. Holland, R. A. Andersen, R. G. Bergman, Comments Inorg. Chem. 1999, 21, 115-129.

[33] For examples of amido Ru complexes obtained by the addition of carbon nucleophiles to a coordinated imine: a) G. C. Martin, J. M. Boncella, E. J. Wucherer, Organometallics 1991, 10, 2804-2811. For examples with other metals: b) G. A. Stark, J. A. Gladysz, Inorg. Chim. Acta 1998, 269,167-180; c) T. Birkle, A. Carbayo, J. V. Cuevas, G. García-Herbosa, A. Muñoz, Eur. J. Inorg. Chem. 2012, 2259-2266; d) S. G. Feng, J. L. Templeton, Organometalllics 1992, 11, 1295-1303; e) S. R. Golisz, N. Hazari, J. A. Labinger, J. E. Bercaw, J. Org. Chem. 2009, 74, 8441-8443.

[34] For examples of $\mathrm{N}$-arylamido $\mathrm{Ru}(\mathrm{II})$ complexes: a) K. N. Jayaprakash, $\mathrm{T}$. B. Gunnoe, P. D. Boyle, Inorg. Chem. 2001, 40, 6481-6486; b) D. Conner, K. N. Jayaprakash, T. B. Gunnoe, P. D. Boyle, Inorg. Chem. 2002, 41, 3042-3049; c) J. M. Boncella, T. M. Eve, B. Rickman, K. A. Abboud, Polyhedron 1998, 17, 725-736; d) J. F. Hartwig, R. A. Andersen, R. G. Bergman, Organometallics 1991, 10, 1875-1887; e) H. E. Bryndza, L. K. Fong, R. A. Paciello, W. Tam, J. E. Bercaw, J. Am. Chem. Soc. 1987, 109, 1444-1456; f) J. F. Hartwig, R. A. Andersen, R. G. Bergman, J. Am. Chem. Soc. 1989, 111, 2717-2719; g) A. K. Singh, B. G. Levine, R. J. Staples, A. L. Odom, Chem. Commun. 2013, 49, 10799-10801; h) 
J. Zhang, T. B. Gunnoe, J. L. Petersen, Inorg. Chem. 2005, 44, 28952907.

[35] For examples of $\beta$-hydrogen elimination in late-metal amido complexes: a) H. E. Bryndza, W. Tam, Chem. Rev. 1988, 88, 1163-1188; b) M. D. Fryzuk, C. D. Montgomery, Coord. Chem. Rev. 1989, 95, 1-40; c) R. Abbel, K. Abdur-Rashid, M. Faatz, A. Hadzovic, A. J. Lough, R. H. Morris, J. Am. Chem. Soc. 2005, 127, 1870-1882; d) J. F. Hartwig, J. Am. Chem. Soc. 1996, 118, 7010-7011; e) S. Wagaw, R. A. Rennels, S. L. Buchwald, J. Am. Chem. Soc. 1997, 119, 8451-8458.

[36] Unless otherwise said, energy barriers throughout the computational section are zero point-corrected potential energy variations in continuum THF.

[37] Contrary to observed with Shvo's catalyst (see ref. 14f) and a iridium catalyst reported by Oro et al., in this transition state the $\mathrm{H} \cdots \mathrm{C}$ bond formation is more advanced than that of the new $\mathrm{H} \cdots \mathrm{N}$ bond. M. Martín, E. Sola, S. Tejero, J. L. Andrés, L. A. Oro, Chem. Eur. J. 2006, 12, 40434056.

[38] a) O. Eisenstein, R. H. Crabtree, New J. Chem. 2013, 37, 21-27; b) R. Noyori, C. A. Sandoval, K. Muñiz, T. Ohkuma, Philos. Trans. R. Soc. A 2005, 363, 901-912; c) K. Abdur-Rashid, S. E. Clapham, A. Hadzovic, J. N. Harvey, A. J. Lough, R. H. Morris, J. Am. Chem. Soc. 2002, 124, 15104-15118; d) T. Leyssens, D. Peeters, J. N. Harvey, Organometallics 2008, 27, 1514-1523.

[39] For an example of a related stepwise hydrogen transfer from a Ru-CNN pincer to carbonate, see: F. Hasanayn, A. Baroudi, A. A. Bengali, A. S. Goldman, Organometallics 2013, 32, 6969-6985, and references therein.

[40] P. A. Dub, N. J. Henson, R. L. Martin, J. C. Gordon, J. Am. Chem. Soc. 2014, 136, 3505-3521.

[41] N. Ahmad, J. J. Levison, S. D. Robinson, M. F. Uttley, E. R. Wonchoba, G. W. Parshall, Inorg. Synth. 1974, 15, 45-64.

[42] Gaussian 09, Revision D.01, M. J. Frisch, G. W. Trucks, H. B. Schlegel, G. E. Scuseria, M. A. Robb, J. R. Cheeseman, G. Scalmani, V. Barone, B. Mennucci, G. A. Petersson, H. Nakatsuji, M. Caricato, X. Li, H. P. 
Hratchian, A. F. Izmaylov, J. Bloino, G. Zheng, J. L. Sonnenberg, M. Hada, M. Ehara, K. Toyota, R. Fukuda, J. Hasegawa, M. Ishida, T. Nakajima, Y. Honda, O. Kitao, H. Nakai, T. Vreven, J. A. Montgomery, Jr., J. E. Peralta, F. Ogliaro, M. Bearpark, J. J. Heyd, E. Brothers, K. N. Kudin, V. N. Staroverov, T. Keith, R. Kobayashi, J. Normand, K. Raghavachari, A. Rendell, J. C. Burant, S. S. lyengar, J. Tomasi, M. Cossi, N. Rega, J. M. Millam, M. Klene, J. E. Knox, J. B. Cross, V. Bakken, C. Adamo, J. Jaramillo, R. Gomperts, R. E. Stratmann, O. Yazyev, A. J. Austin, R. Cammi, C. Pomelli, J. W. Ochterski, R. L. Martin, K. Morokuma, V. G. Zakrzewski, G. A. Voth, P. Salvador, J. J. Dannenberg, S. Dapprich, A. D. Daniels, O. Farkas, J. B. Foresman, J. V. Ortiz, J. Cioslowski, and D. J. Fox, Gaussian, Inc., Wallingford CT, 2013.

[43] a) C. Adamo, V. Barone. J. Chem. Phys. 1999, 110, 6158-6169; b) This functional has been shown to reproduce the uniform electron gas limit (UEG) and being effective in describing metal hydride, dihydrogen and hydrogen bond situations; D. A. Pantazis, J. E. McGrady, F. Maseras, M. Etienne, J. Chem. Theor. Comput. 2007, 3, 1329-1336.

[44] a) W. J. Hehre, R. Ditchfield, J. A. Pople, J. Phys. Chem. 1972, 56, 22572261; b) P. C. Hariharan, J. A. Pople, Theor. Chim. Acta. 1973, 28, 213222; c) M. M. Francl, W. J. Pietro, W. J. Hehre, J. S. Binkley, M. S. Gordon, D. J. DeFrees, J. A. Pople, Chem. Phys. 1982, 77, 3654-3665.

[45] D. Andrae, U. Haeussermann, M. Dolg, H. Stoll, H. Preuss, Theor. Chim. Acc. 1990, 77, 123-141.

[46] A. V. Marenich, C. J. Cramer, D. G. Truhlar, J. Phys. Chem. B 2009, 113, 6378-6396. 

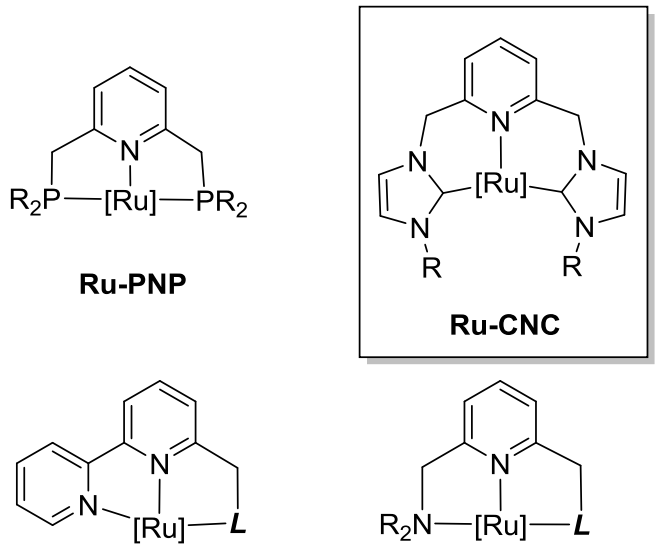

$$
\begin{array}{r}
L=\mathrm{PR}_{2}, \mathrm{Ru}-\mathrm{PNN} \\
\mathrm{NHC}, \mathrm{Ru}-\mathrm{CNN}
\end{array}
$$

Figure 1. Lutidine-derived pincer ruthenium complexes. 


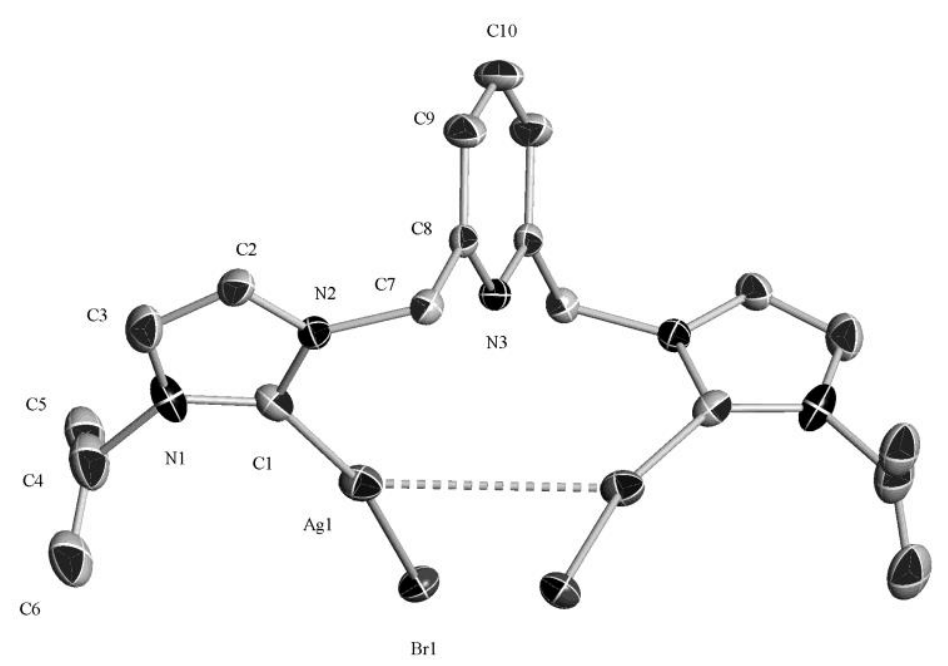

[Figure 2; upper]

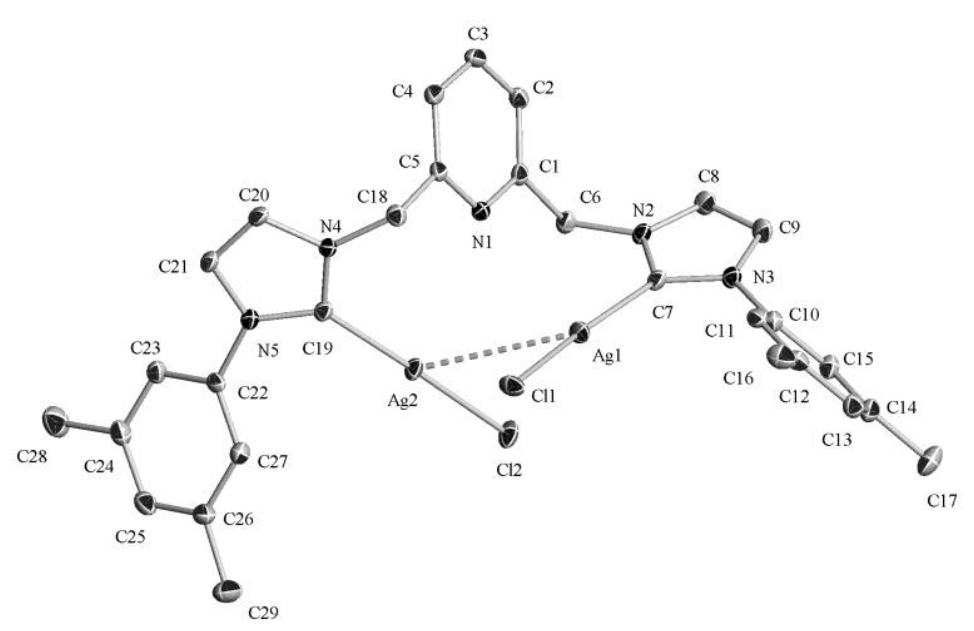

[Figure 2; bottom]

Figure 2. ORTEP drawings at $30 \%$ ellipsoid probability of complexes $\mathbf{2 a}(\mathbf{B r})$ (upper) and $\mathbf{2} \mathbf{d}(\mathbf{C l}) \cdot 2 \mathrm{CHCl}_{3}$ (bottom). Hydrogen atoms and solvent molecules have been omitted for clarity. Selected bond lengths $[\AA \tilde{A}]$ and angles $\left[{ }^{\circ}\right]$ for 2a(Br): Ag1-Ag2 3.3192(7); Ag1-Br1 2.4478(5); Ag1-C1 2.084(4); Br1-Ag1-C1 165.68(11). Selected bond lengths $[A ́]$ and angles [ $\left.{ }^{\circ}\right]$ for $\mathbf{2 d}(\mathbf{C l}) \cdot 2$ $\mathrm{CHCl}_{3}: \mathrm{Ag} 1-\mathrm{Ag} 2$ 3.2436(5); Ag1-Cl1 2.3625(11); Ag1-C7 2.080(4); Cl1-Ag1-C7 166.75(13). 


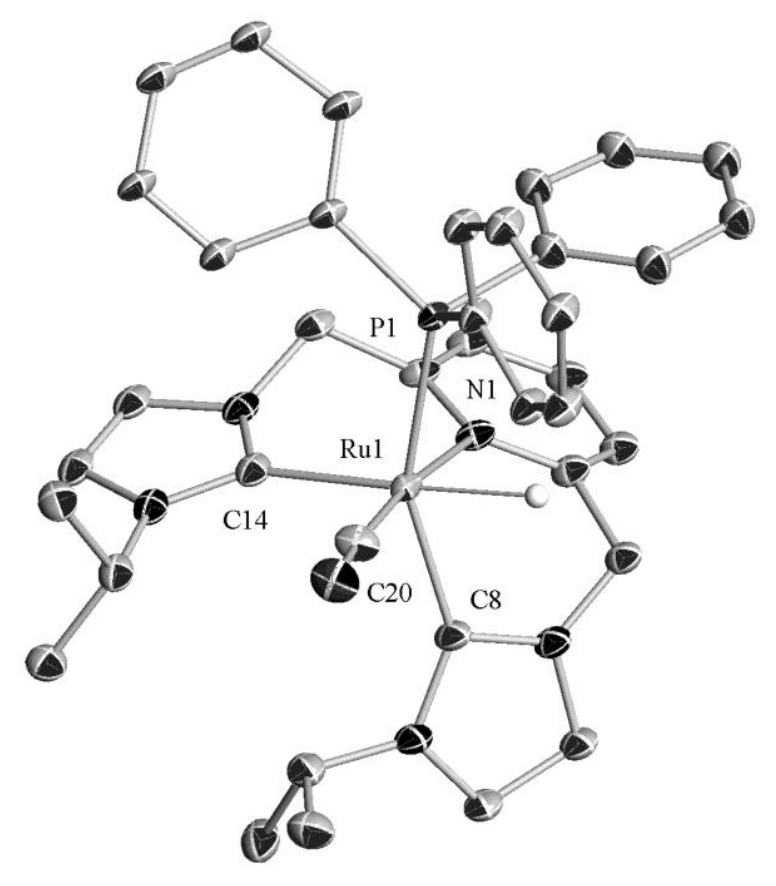

Figure 3. ORTEP drawing at $30 \%$ ellipsoid probability of the cationic component of complex $3 \mathrm{a}\left(\mathrm{BF}_{4}\right)$. Hydrogen atoms, except for the hydrido ligand, have been omitted for clarity. Selected bond lengths $[\AA \hat{]}]$ and angles [ $\left.{ }^{\circ}\right]$ : $\mathrm{Ru}(1)-\mathrm{C}(8) \quad 2.084(19) ; \quad \mathrm{Ru}(1)-\mathrm{C}(14) \quad 2.117(19) ; \quad \mathrm{Ru}(1)-\mathrm{N}(1) \quad 2.233(16) ;$ $\mathrm{Ru}(1)-\mathrm{C}(20)$ 1.79(2); $\mathrm{C}(8)-\mathrm{Ru}(1)-\mathrm{C}(14)$ 101.3(8). 


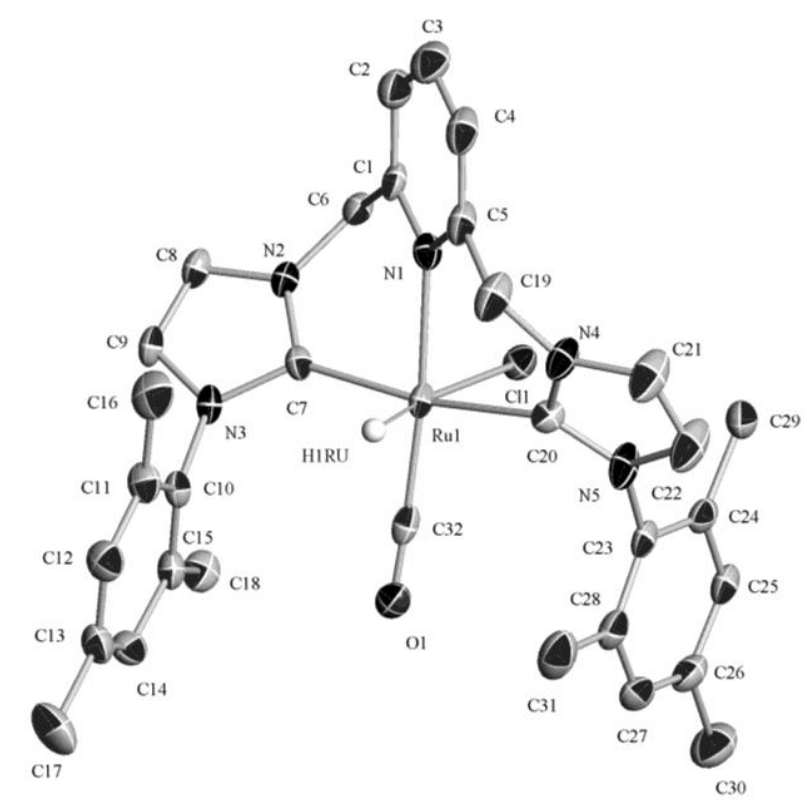

Figure 4. ORTEP drawing at $30 \%$ ellipsoid probability of complex $4 \mathbf{e} \cdot \mathrm{CH}_{2} \mathrm{Cl}_{2}$. Hydrogen atoms, with exception of the hydrido ligand, and solvent molecule have been omitted for clarity. Selected bond lengths $[\AA \hat{]}]$ and angles $\left[{ }^{\circ}\right]$ : $\mathrm{Ru}(1)-\mathrm{C}(7)$ 2.044(7); Ru(1)-C(20) 2.127(6); Ru(1)-N(1) 2.209(8); Ru(1)-C(32) 1.841(10); Ru(1)-Cl(1) 2.565(2); C(7)-Ru(1)-C(20) 170.0(3); C(32)-Ru(1)-N(1) 175.0(4). 


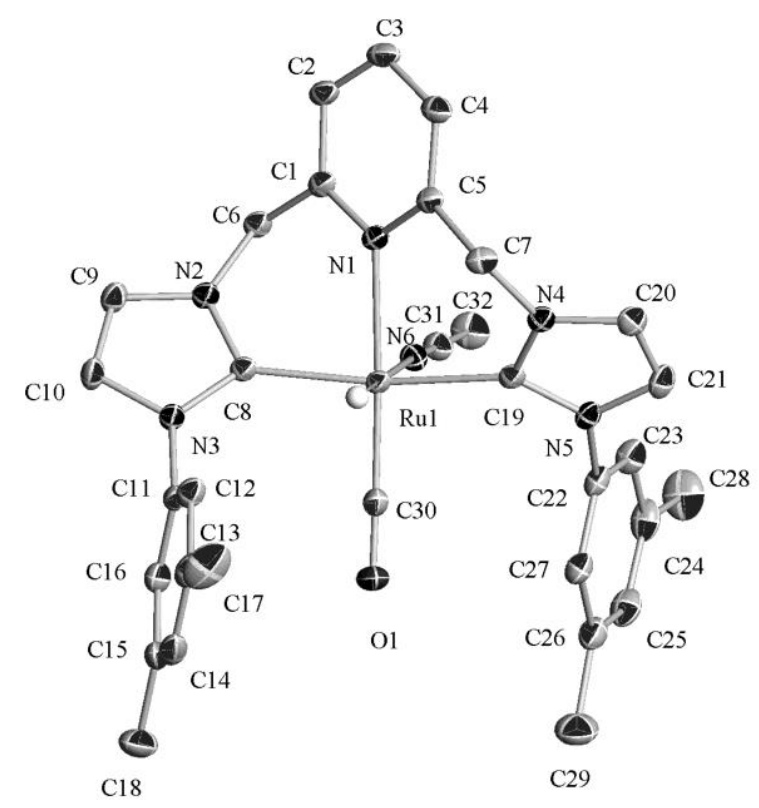

Figure 5. ORTEP drawing at $30 \%$ ellipsoid probability of the cationic component of complex $\mathbf{5 d}\left(\mathbf{B F}_{4}\right) \cdot \mathrm{C}_{7} \mathrm{H}_{8}$. Hydrogen atoms, with exception of the hydrido ligand, and solvent molecule have been omitted for clarity. Selected bond lengths $[\AA \hat{]}]$ and angles [0]: $\mathrm{Ru}(1)-\mathrm{C}(8)$ 2.055(2); $\mathrm{Ru}(1)-\mathrm{C}(19)$ 2.083(3); $\mathrm{Ru}(1)-\mathrm{N}(1) \quad 2.201(2) ; \quad \mathrm{Ru}(1)-\mathrm{C}(30) \quad 1.820(3) ; \quad \mathrm{Ru}(1)-\mathrm{N}(6) \quad 2.169(2) ;$ $\mathrm{C}(8)-\mathrm{Ru}(1)-\mathrm{C}(19)$ 169.33(10); C(30)-Ru(1)-N(1) 174.91(11). 

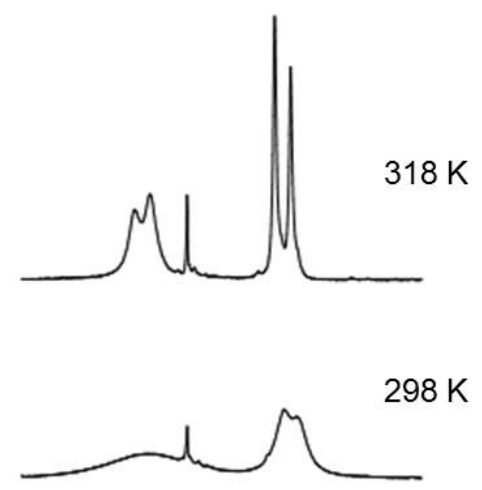

$288 \mathrm{~K}$
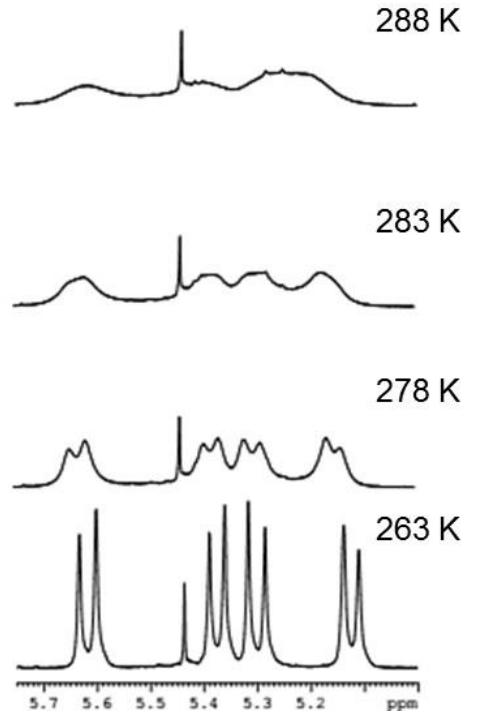

Figure 6. VT- ${ }^{1} \mathrm{H}$ NMR spectra of complex $\mathbf{5 e}\left(\mathrm{BF}_{4}\right)$ in $\mathrm{CD}_{3} \mathrm{CN}$. 


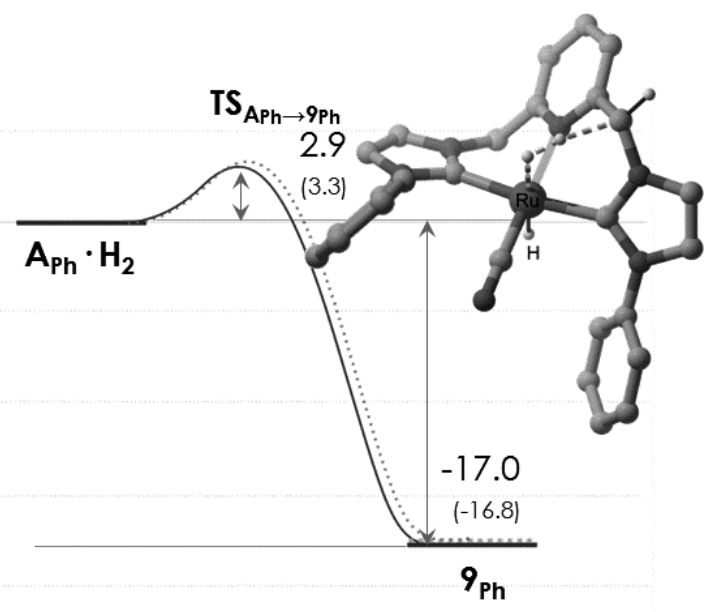

Figure 7. Heterolytic $\mathrm{H}_{2}$ activation at $\mathbf{A}_{\mathbf{P h}}$. Data are zero point- and dispersioncorrected $\Delta E\left(\mathrm{kcal} \cdot \mathrm{mol}^{-1}\right)$ in continuum THF (the dotted line and data in parentheses correspond to $\Delta G$ in THF). The inset represents the DFT-optimized geometry of the corresponding transition state.

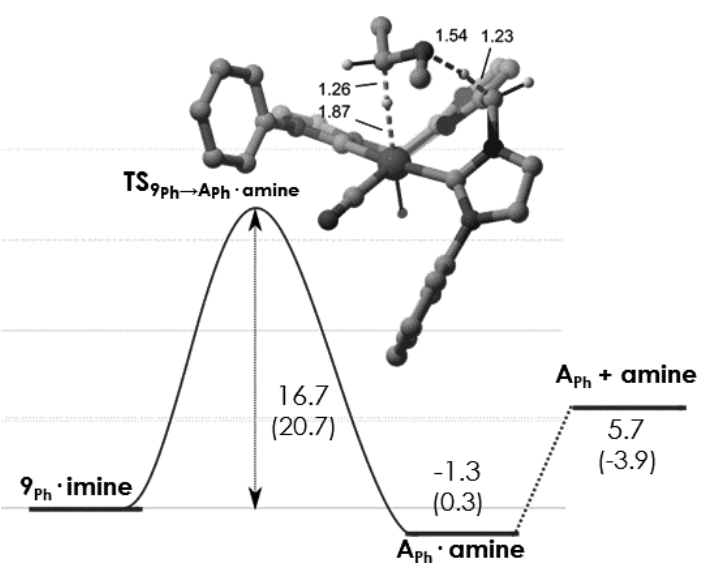

Figure 8. Energy profile of the simultaneous transfer of two $\mathrm{H}$ atoms to $\mathrm{N}$ methylethanimine. Zero point and dispersion-corrected $\Delta E\left(\mathrm{kcal} \cdot \mathrm{mol}^{-1}\right)$ in continuum THF (data in parentheses correspond to $\Delta G$ in THF). The inset represents the DFT-optimized geometry of the corresponding transition state. 


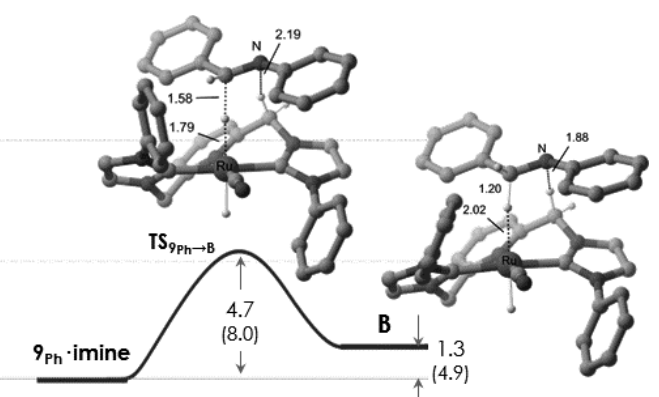

Figure 9. Energy profile for the transfer of one hydride from $9_{\mathrm{Ph}}$ to $\mathrm{N}$ benzylideneaniline. Zero point and dispersion-corrected $\Delta E\left(\mathrm{kcal} \cdot \mathrm{mol}^{-1}\right)$ in continuum THF (data in parentheses correspond to $\Delta G$ in THF). The insets represent the DFT-optimized geometries of the corresponding transition state and of the resulting ion pair, $\mathbf{B}$.

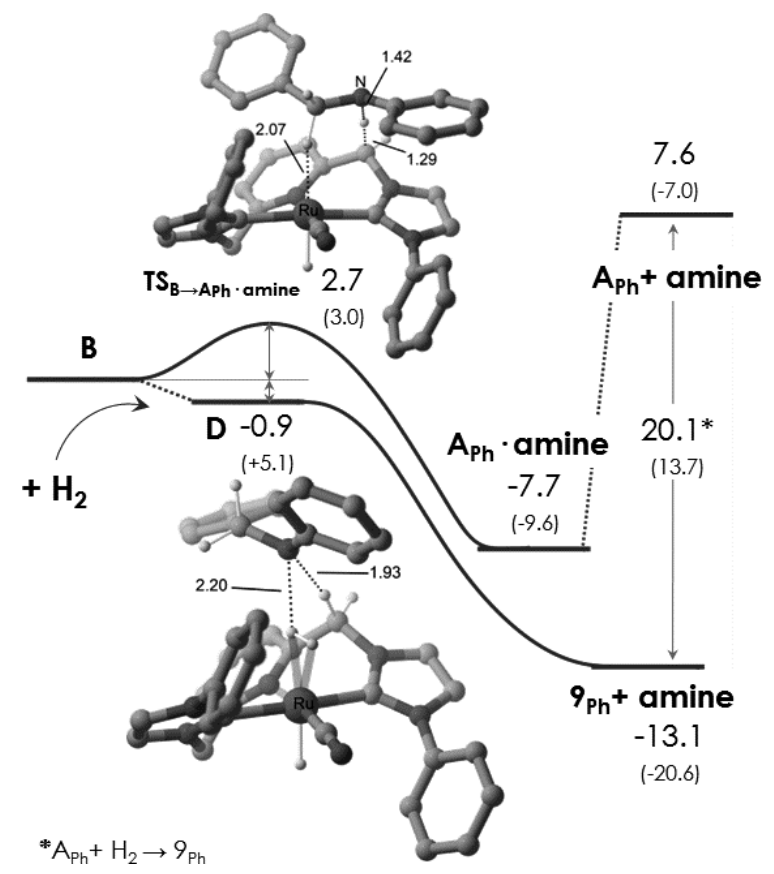

Figure 10. Competing protonation of the benzyl(phenyl)amide anion by $\mathrm{CH}_{2}$ fragment of the ion-pair $\mathbf{B}$ or by the dihydrogen ligand of ion-pair $\mathbf{D}$. Zero pointand dispersion-corrected $\Delta E\left(\mathrm{kcal} \cdot \mathrm{mol}^{-1}\right)$ in continuum THF (data in parentheses correspond to $\Delta G$ in THF). The insets represent the DFT-optimized geometries of the transition state of the hydrogen transfer from $\mathbf{B}$ (top) and of the ion-pair $\mathbf{D}$ (bottom). 
<smiles></smiles>

1a(Cl); $R=i \mathrm{Pr}, \mathrm{X}=\mathrm{Cl}$

$\mathbf{1 a}(\mathrm{Br}) ; \mathrm{R}=\mathrm{Pr}, \mathrm{X}=\mathrm{Br}$

1b(CI); R = Hexyl, $X=C$

1c(Br); $R=$ Neopentyl, $X=B r$

1d(Cl); $R=3,5$-Xilyl, $X=\mathrm{Cl}$

1e(Cl); $R=2,4,6-$ Mesityl, $X=C l$

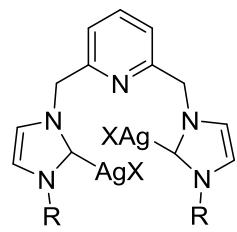

2a(Cl); $\mathrm{R}=i \mathrm{Pr}, \mathrm{X}=\mathrm{Cl}$

$2 \mathrm{a}(\mathrm{Br}) ; \mathrm{R}=i \mathrm{Pr}, \mathrm{X}=\mathrm{Br}$

2b(Cl); $R=$ Hexyl, $X=C l$

2c(Br); $R=$ Neopentyl, $X=B$

2d(Cl); $R=3,5$-Xilyl, $X=C l$

2e(CI); $R=2,4,6$-Mesityl, $X=C l$
$\mathrm{RuHCl}(\mathrm{CO})\left(\mathrm{PPh}_{3}\right)_{3}$

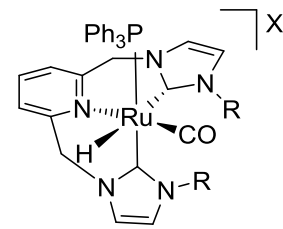

$3 \mathrm{a}(\mathrm{Cl}) ; \mathrm{R}=\mathrm{iPr}, \mathrm{X}=\mathrm{Cl}$

$3 \mathrm{a}\left(\mathrm{BF}_{4}\right) ; \mathrm{R}=\mathrm{Pr}, \mathrm{X}=\mathrm{BF}_{4}$ (after treatment with $\mathrm{NaBF}_{4}$ )

$3 b(C l) ; R=\mathrm{Hexyl}, \mathrm{X}=\mathrm{Cl}$

$3 c(B r) ; R=$ Neopentyl, $X=B r$ (after treatment with $\mathrm{NaBr}$ ) 3d(CI); $R=3,5$-Xilyl, $X=C$

Scheme 1. Synthesis of silver (2) and ruthenium (3) complexes.<smiles></smiles>

\section{$\mathrm{RuHCl}(\mathrm{CO})\left(\mathrm{PPh}_{3}\right)_{3}$}

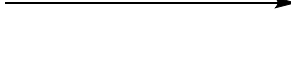

d(CI), $\mathrm{Ar}=3,5$-xilyl

$2 \mathrm{e}(\mathrm{Cl}), \mathrm{Ar}=2,4,6$-mesityl

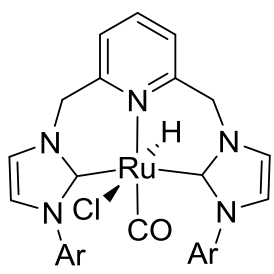

4d, 4e

$\mathrm{NaBF}_{4}$ $\mathrm{MeCN}$

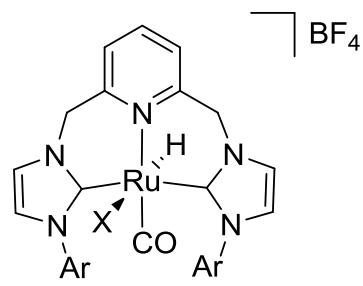

$5 d\left(B_{4}\right), 5 e\left(B F_{4}\right)$

$X=\mathrm{MeCN}$

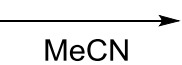

$5 d(\mathrm{Cl}), 5 \mathrm{e}(\mathrm{Cl})$

$\mathrm{X}=\mathrm{MeCN}$

Scheme 2. Synthesis of complexes $4,5(\mathrm{Cl})$ and $5\left(\mathrm{BF}_{4}\right)$. 


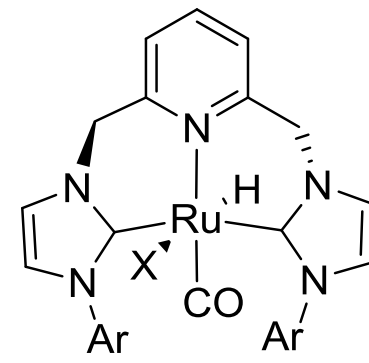<smiles>[Z]C1([R]([H])(N)C2N([Al])C=CN2CC)N(C)C=CN1[Al]</smiles>

$\mathrm{X}=\mathrm{Cl}(4), \mathrm{MeCN}$ (cationic fragment of $\mathbf{5}(\mathrm{Cl})$ and $5\left(\mathrm{BF}_{4}\right)$ )

Scheme 3. Enantiomers interconversion for $\mathbf{4}, \mathbf{5}(\mathbf{C l})$ and $\mathbf{5}\left(\mathbf{B F}_{\mathbf{4}}\right)$ in solution.<smiles>c1ccc2c(c1)cnc1ccccc12</smiles>

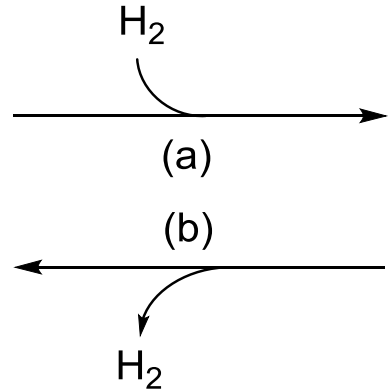<smiles>c1ccc2c(c1)CNc1ccccc1-2</smiles>

Conditions: a) $3 a(C l)$ or $3 b(C l)$

10 bar $\mathrm{H}_{2}, 2 \mathrm{Me}-\mathrm{THF}, 80^{\circ} \mathrm{C}, \mathrm{S} / \mathrm{C} / \mathrm{tBuOK}=250 / 1 / 10$

b) $\mathbf{3 b}(\mathrm{Cl})$, dioxane, reflux, $\mathrm{S} / \mathrm{C} / \mathrm{tBuOK}=100 / 1 / 10$

Scheme 4. Reversible hydrogenation of phenanthridine. 


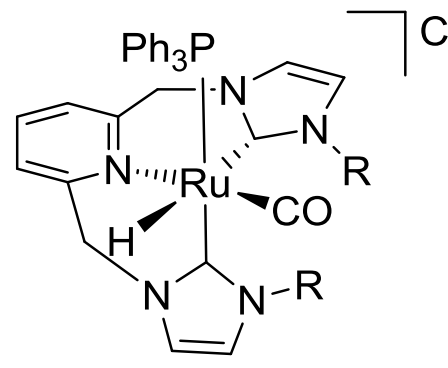

$3 a(C l), 3 d(C l)$
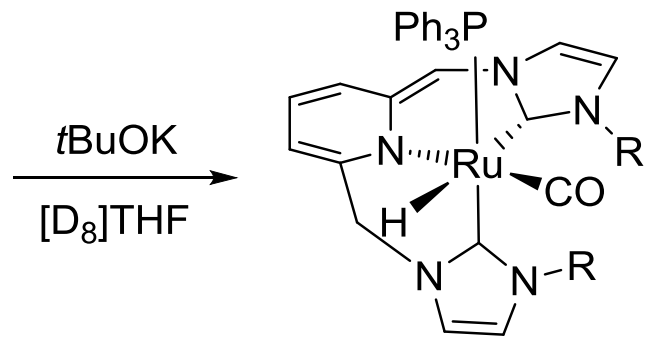

$8 a, 8 d$

Scheme 5. Deprotonation reactions of complexes $3 a(C l)$ and $3 d(C l)$.

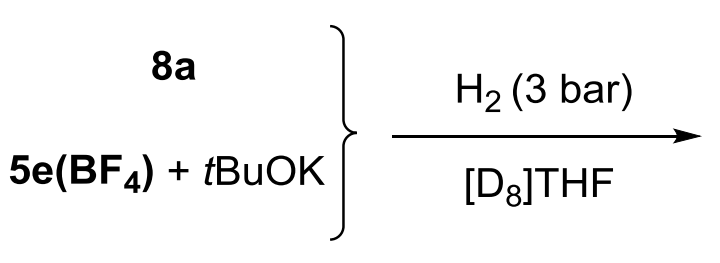

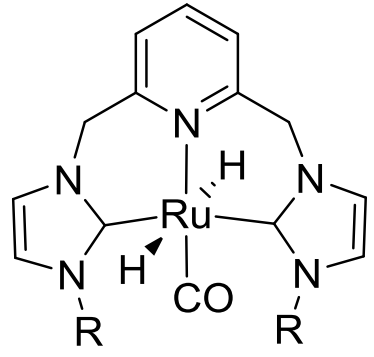

$$
\begin{aligned}
\mathrm{R}= & \mathrm{iPr}, \mathbf{9 a} \\
& \text { mesityl, 9e }
\end{aligned}
$$

Scheme 6. Generation of dihydrido complexes 9.
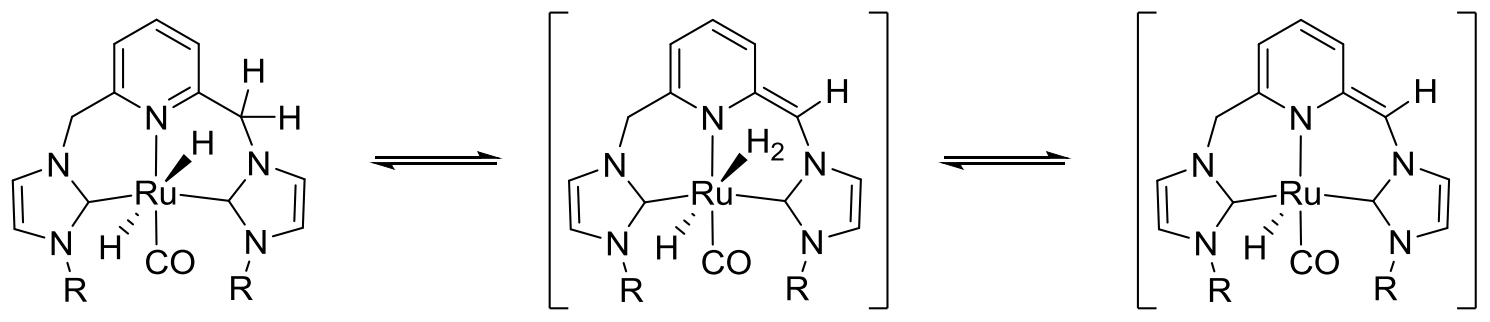

$$
+\mathrm{H}_{2}
$$

Scheme 7. Equilibria involved in the exchange of complex $9 e$ and $\mathrm{H}_{2}$. 


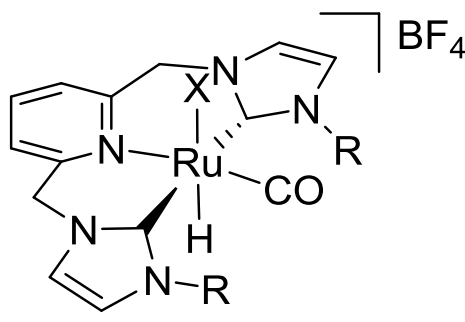

$5 e\left(B_{4}\right) ; X=M e C N$

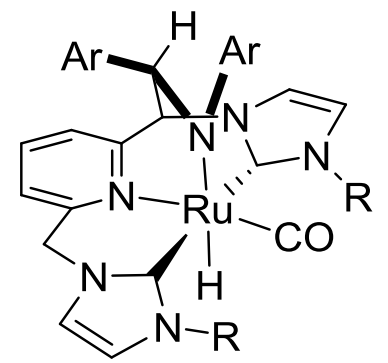

$10 a-d$

Scheme 8. Synthesis of complexes 10a-d.

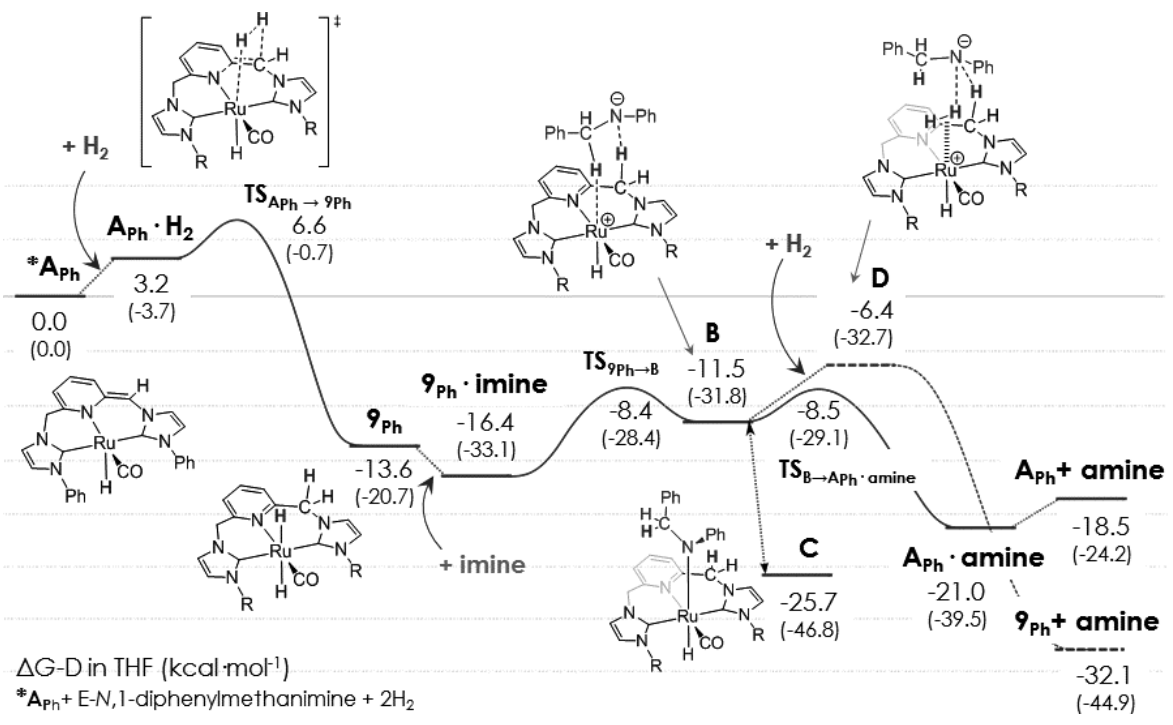

Scheme 9. DFT calculated Free Energy profile of the hydrogenation of $N$ benzylideneaniline by $\mathbf{A}_{\mathrm{Ph}}$ (Zero-Point corrected Energy data is also shown in parenthesis). Note that the origin of energies is $\mathrm{APh}_{\mathrm{Ph}}+2 \mathrm{H}_{2}+$ imine. 
Table 1. Free energy barriers $\left(\Delta G^{\ddagger} T_{\mathrm{c}}\right)$ at coalescence temperature for complexes $\mathbf{4}, \mathbf{5}(\mathbf{C l})$ and $\mathbf{5}\left(\mathbf{B F}_{4}\right)$.

\begin{tabular}{|c|c|c|c|}
\hline Complex & Solvent & $T_{\mathrm{c}}(\mathrm{K})$ & $\Delta G_{T \mathrm{c}}^{\ddagger}\left(\mathrm{Kcal} \mathrm{mol}^{-1}\right)$ \\
\hline $4 d$ & $\mathrm{CD}_{2} \mathrm{Cl}_{2}$ & 288 & 15.1 \\
\hline $4 e$ & & 263 & 13.2 \\
\hline $5 d(C l)$ & $\mathrm{CD}_{3} \mathrm{CN}$ & 303 & 15.7 \\
\hline $5 \mathrm{e}(\mathrm{Cl})$ & & 278 & 14.0 \\
\hline $5 d\left(B_{4}\right)$ & $\mathrm{CD}_{2} \mathrm{Cl}_{2}$ & 313 & 16.1 \\
\hline $5 e\left(B_{4}\right)$ & & 273 & 13.8 \\
\hline $5 d\left(B_{4}\right)$ & $\mathrm{CD}_{3} \mathrm{CN}$ & 308 & 16.4 \\
\hline $5 e\left(B_{4}\right)$ & & 283 & 14.2 \\
\hline
\end{tabular}


Table 2. Hydrogenation of aldimines. ${ }^{[a]}$

\begin{tabular}{|c|c|c|c|c|}
\hline Entry & Imine & Cat. & Conv.(\%) & TOF $\left(h^{-1}\right)$ \\
\hline 1 & & $3 a(C l)$ & 60 & 100.0 \\
\hline 2 & $6 a$ & $3 b(C l)$ & 100 & 166.7 \\
\hline 3 & & $3 c(B r)$ & 26 & 43.3 \\
\hline 4 & & $3 d(C l)$ & 54 & 90.0 \\
\hline 5 & & $4 e$ & 98 & 163.3 \\
\hline 6 & & $3 b(\mathrm{Cl})$ & 100 & 166.7 \\
\hline 7 & & & 80 & 133.3 \\
\hline 8 & & & 21 & 35.0 \\
\hline 9 & & & 54 & 90.0 \\
\hline $10^{[b]}$ & & & 81 & 13.5 \\
\hline
\end{tabular}


$11^{[\mathrm{b}]}$

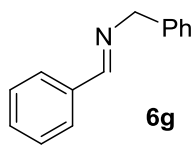

$12^{[b]}$

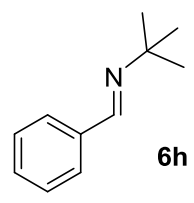

0

0

[a] Reaction conditions, unless otherwise noted: 5 bar $\mathrm{H}_{2}, 70{ }^{\circ} \mathrm{C}$, 2methyltetrahydrofuran, $S / C / B=1000 / 1 / 10$, base: $t B u O K, 6$ h. [S] $=1.4$ M. Conversions were determined by ${ }^{1} \mathrm{H}$ NMR spectroscopy. TOF values as calculated from conversions. [b] $S / C / B=100 / 1 / 10$. 
Table 3. Hydrogenation of ketimines with $\mathbf{3 b}(\mathbf{C l}) .{ }^{[a]}$

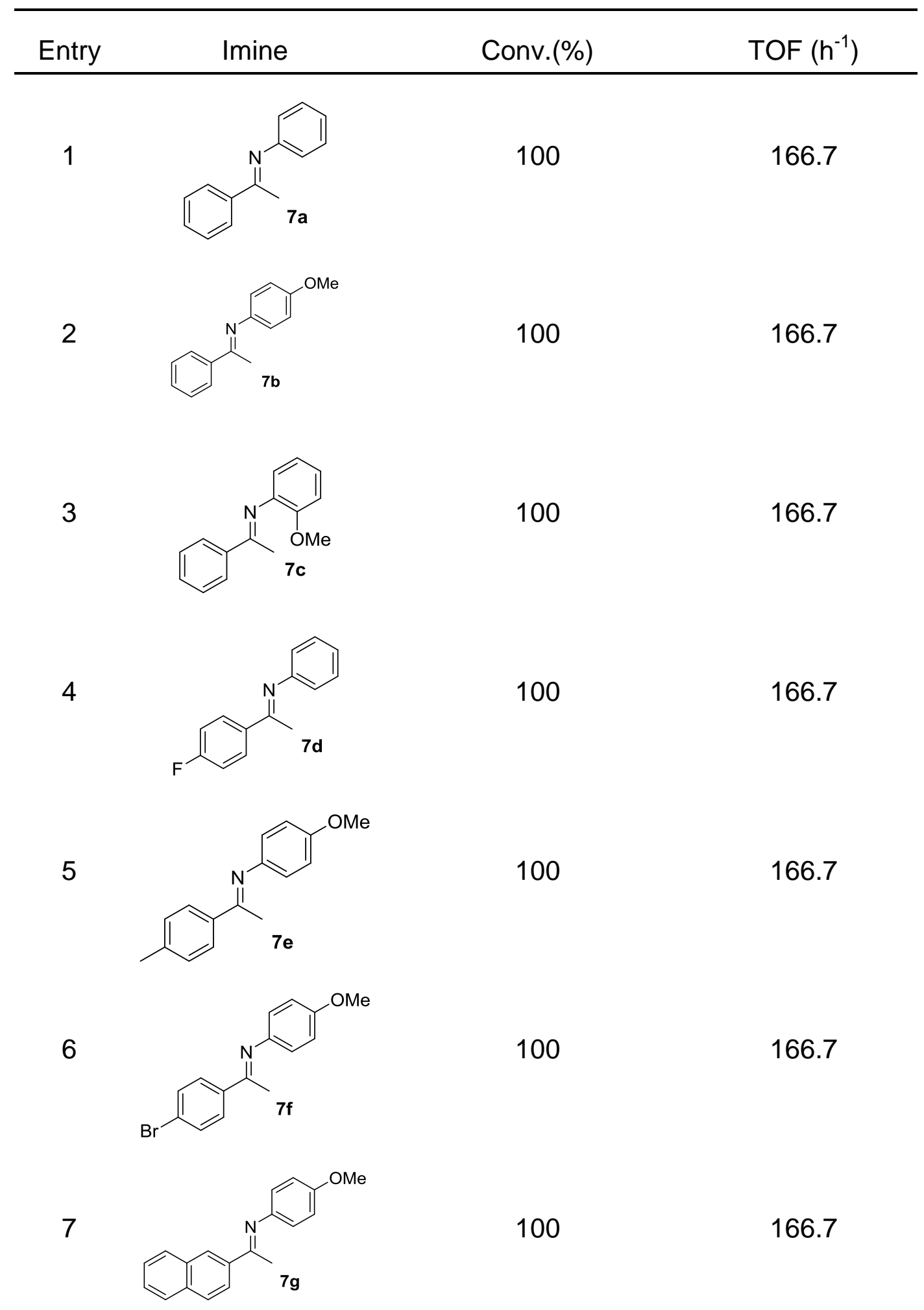


$8^{[\mathrm{b}]}$<smiles>COc1ccc(/N=C(\c2ccccc2)c2cccs2)cc1</smiles>

$9^{[c]}$<smiles>COc1ccc(N=C(C)C(C)C)cc1</smiles>

$10^{[\mathrm{c}]}$
44 1.8

89

74.2

100

83.3

[a] Reaction conditions, unless otherwise noted: 5 bar $\mathrm{H}_{2}, 70{ }^{\circ} \mathrm{C}$, 2methyltetrahydrofuran, $S / C / B=1000 / 1 / 10$, base: $t B u O K, 6$ h. $[S]=1.4$ M. Conversions were determined by ${ }^{1} \mathrm{H}$ NMR spectroscopy. TOF values as calculated from conversions. [b] $80^{\circ} \mathrm{C}, \mathrm{S} / \mathrm{C} / \mathrm{B}=100 / 1 / 10,24$ h. $[c] S / C / B=500 / 1 / 10$. 
TOC

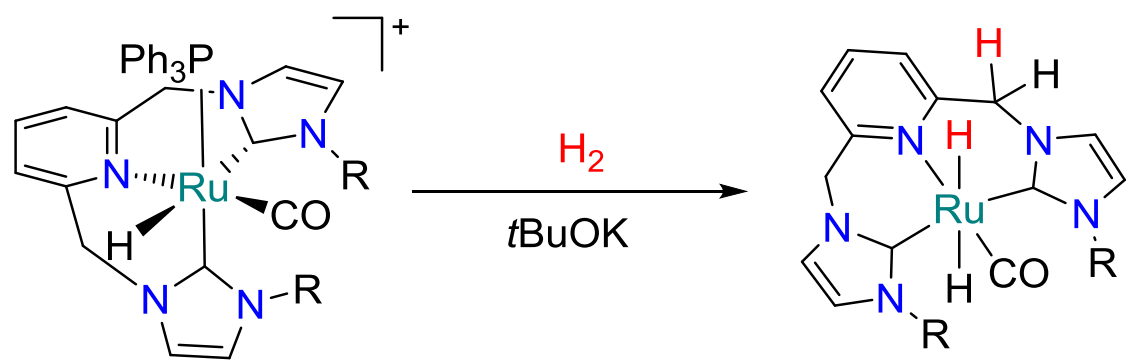

Active catalyst in $\mathrm{C}=\mathrm{N}$ hydrogenation

Facially coordinated Ru-CNC complexes, in the presence of $t \mathrm{BuOK}$, are active catalysts in the hydrogenation of a series of substrates containing $\mathrm{C}=\mathrm{N}$ bonds. Intermediate species in the catalytic cycle have been studied by NMR spectroscopy, whereas DFT calculations support a stepwise outer-sphere mechanism for the hydrogen transfer to the $\mathrm{C}=\mathrm{N}$ bond assisted by either the pincer ligand or a second coordinated $\mathrm{H}_{2}$ molecule.

Keywords: Ruthenium • Homogeneous catalysis • Tridentate ligands • Carbene ligands $\cdot$ Hydrogenation 